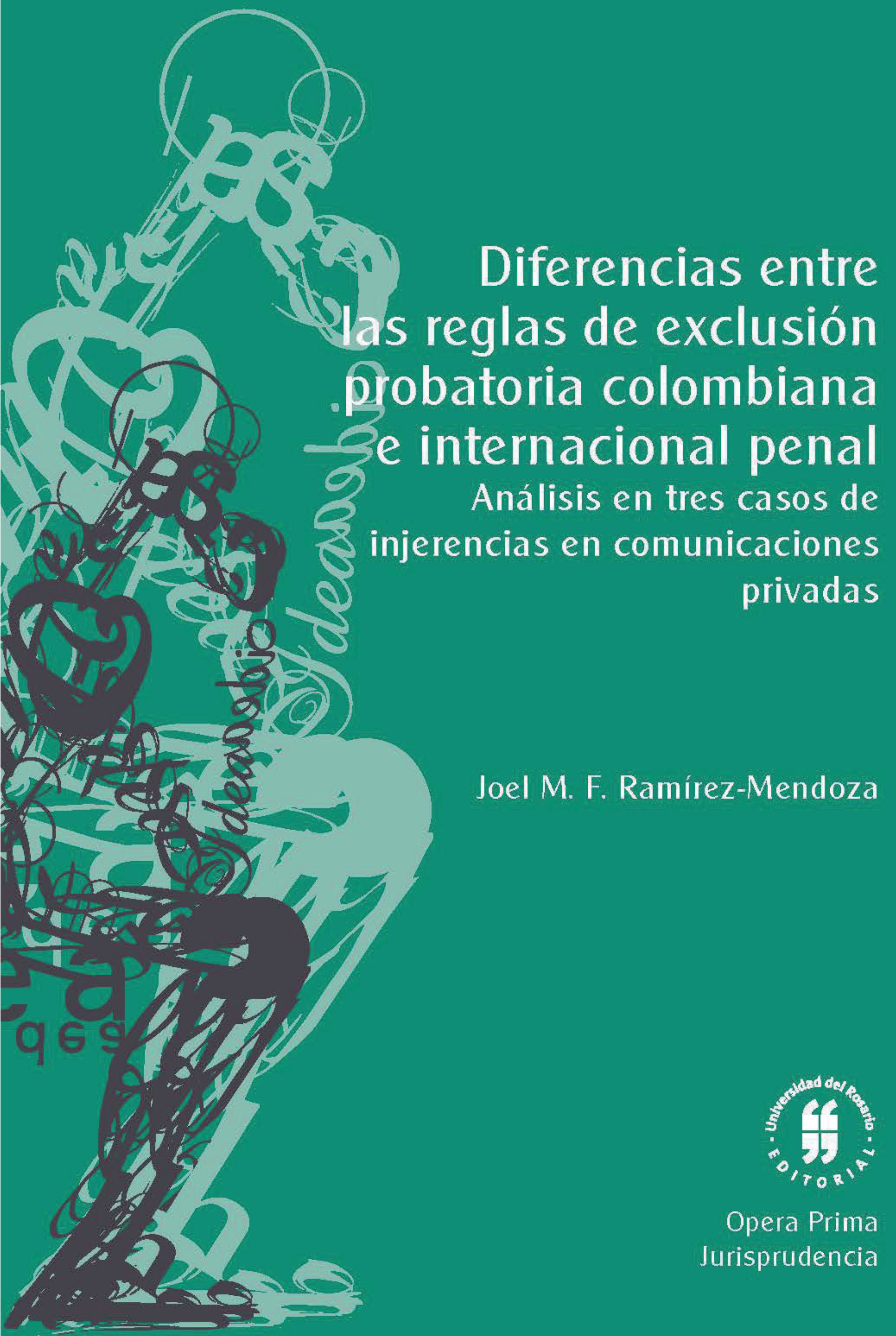



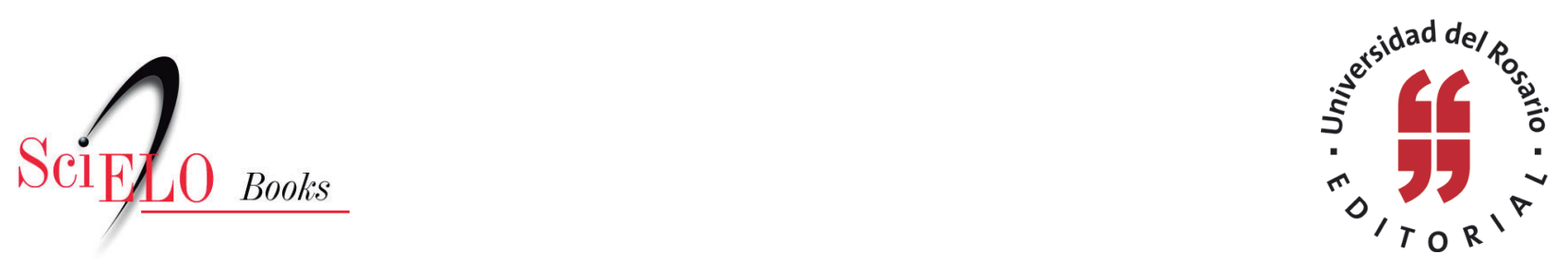

\title{
Diferencias entre las reglas de exclusión probatoria colombiana e internacional penal. Análisis en tres casos de injerencias en comunicaciones privadas
}

\author{
Joel M. F. Ramírez-Mendoza
}

\section{SciELO Books / SciELO Livros / SciELO Libros}

RAMÍREZ MENDONZA, J.M.F. Referencias. In: Diferencias entre las reglas de exclusión probatoria colombiana e internacional penal. Análisis en tres casos de injerencias en comunicaciones privadas [online]. Bogotá: Editorial Universidad del Rosario, 2015, 206 p. Opera prima collection. ISBN: 978958-738-658-5. https://doi.org/10.7476/9789587386585.

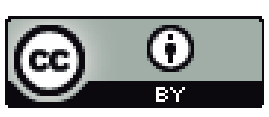

All the contents of this work, except where otherwise noted, is licensed under a Creative Commons Attribution 4.0 International license.

Todo o conteúdo deste trabalho, exceto quando houver ressalva, é publicado sob a licença Creative Commons Atribição $\underline{4.0}$.

Todo el contenido de esta obra, excepto donde se indique lo contrario, está bajo licencia de la licencia Creative Commons Reconocimento 4.0. 


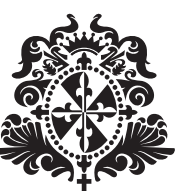

Universidad del

Rosario 



\title{
DIFERENCIAS ENTRE LAS REGLAS DE EXCLUSIÓN PROBATORIA COLOMBIANA E INTERNACIONAL PENAL
}

\author{
Análisis en tres casos de injerencias \\ en comunicaciones privadas
}


Ramírez Mendoza, Joel M. F.

Diferencias entre las reglas de exclusión probatoria colombiana e internacional penal. Análisis en tres casos de injerencias en comunicaciones privadas / Joel M. F. Ramírez Mendoza. - Bogotá: Editorial Universidad del Rosario, Facultad de Jurisprudencia, 2015.

208 páginas. (Colección Opera Prima, Facultad de Jurisprudencia)

Incluye referencias bibliográficas.

ISBN: 978-958-738-657-8 (impreso)

ISBN: 978-958-738-658-5 (digital)

Derecho penal / Derecho internacional penal / Comunicaciones - Legislación / I. Universidad del Rosario. Facultad de Jurisprudencia / II. Título / III. Serie.

341.7

SCDD 20

Catalogación en la fuente - Universidad del Rosario. Biblioteca

jda

Agosto 20 de 2015

Hecho el depósito legal que marca el Decreto 460 de 1995 


\section{DIFERENCIAS ENTRE LAS REGLAS DE EXCLUSIÓN PROBATORIA COLOMBIANA E INTERNACIONAL PENAL Análisis en tres casos de injerencias en comunicaciones privadas}

JOEL M. F. RAMÍREZ-MENDOZA 
(C) Editorial Universidad del Rosario

(C) Universidad del Rosario

Facultad de Jurisprudencia

(C) Joel M. F. Ramírez Mendoza

Editorial Universidad del Rosario

Carrera 7 No 12B-41, oficina 501

Teléfono 2970200

editorial.urosario.edu.co
Primera edición: Bogotá D.C., septiembre de 2015

ISBN: 978-958-738-XXX-X (impreso)

ISBN: 978-958-738-XXX-X (digital)

Coordinación editorial:

Editorial Universidad del Rosario

Corrección de estilo: Ludwing Cepeda Aparicio

Diseño de cubierta y diagramación:

Precolombi EU-David Reyes

Impresión: Digiprint

Impreso y hecho en Colombia

Printed and made in Colombia

Fecha de evaluación: 09 de marzo de 2015

Fecha de aceptación: 17 de julio de 2015

Todos los derechos reservados. Esta obra no puede ser reproducida sin el permiso previo por escrito de la Editorial Universidad del Rosario. 


\section{Contenido}

\section{Contenido}

Siglas y abreviaturas....................................................................... 15

\section{Introducción}

Presentación de los tres casos ........................................... 17

1. El caso de Juan Carlos Castillo por concierto

para delinquir, tráfico y porte de armas

de defensa personal y tráfico de armas

de uso privativo de las fuerzas armadas................... 21

2. El caso de la masacre de Macayepo............................. 23

3. El caso del coronel Alfonso Plazas Vega

y la toma al Palacio de Justicia

Capítulo primero

Exclusión probatoria por injerencias

al derecho a la intimidad

en el derecho colombiano........................................... $\quad 35$

Introducción................................................................... 35

1.1. Derecho a la intimidad y su relación

con la interceptación de comunicaciones ................ 35 


\subsubsection{Fundamentos de protección} de la intimidad como expresión de la dignidad humana....................................

1.1.2. La protección de las comunicaciones como una manifestación del derecho a la intimidad

1.1.3. Excepción: el derecho a la intimidad cede ante el derecho a la información por autorización judicial

1.2. Derecho al debido proceso y su relación con el derecho a la intimidad................................... 56 1.2.1. Breve descripción de los procesos penales en Colombia

1.2.2.1. Sistemas procesales antecesores a la Ley 906 de 2004 .......................... 57

1.2.2.2 Descripción general del proceso penal vigente

1.2.2.3 Descripción del proceso para desarrollar la interceptación de comunicaciones 66

1.2.3. Comentarios sobre las actividades

de inteligencia y contrainteligencia

1.2.3.1. Prueba ilícita, regla de exclusión y prueba derivada ............................... 80

1.2.3.2. Prueba ilícita y regla de exclusión.... 84

1.2.3.3. Prueba derivada y sus excepciones en la regla de exclusión .......................

Conclusiones: aplicación de lo expuesto en los tres casos. 


\section{Capítulo segundo}

Licitud de injerencias de comunicaciones en el derecho internacional humanitario y derecho internacional de los derechos humanos .... 103

Introducción................................................................... 103

2.1.Las interceptaciones de comunicaciones

a la luz del DiH ...................................................... 103

2.2. Definición de conflicto armado ................................ 104

2.3. Fin, objeto y principios rectores del $\mathrm{DIH}$ y sus efectos en las injerencias de comunicaciones..................................................... 107

2.4. Las interceptaciones de comunicaciones a la luz del DIDH..................................................... 118

2.4.1.La relación entre el DIH y el DIDH ................ 118

2.4.2. Análisis de las injerencias de comunicaciones a la luz DIDH.................. 125 2.4.2.1. Desarrollo de injerencias de comunicaciones en el Sistema Interamericano de Derechos Humanos........................................... 126

2.4.2.2. Desarrollo de la regla de exclusión en el Sistema Europeo de Derechos Humanos con base en casos de injerencias en las comunicaciones....

Conclusiones: aplicación a los tres casos expuestos.... 134 


\section{Capítulo tercero}

Licitud de las injerencias en las comunicaciones a la luz del derecho internacional penal..................... 139

Introducción............................................................... 139

3.1.Las interceptaciones a la Luz del Estatuto de Roma y la Corte Penal Internacional ................ 139

3.1.1. La relación del DIH y el DIDH con el Estatuto de Roma (ER)

3.1.2. La admisibilidad de la prueba producida

por injerencias a la intimidad ante la Corte Penal Internacional ........................ 144

3.1.2.1. La fiabilidad de la prueba ................. 147

3.1.2.2. El perjuicio al Estatuto o al juicio.... 150

3.2. Las interceptaciones de comunicaciones a la luz del TPIY

3.2.1. La admisibilidad de la prueba obtenida por injerencias a la intimidad ante el TPIY ... 153

3.2.1.1. La fiabilidad de la prueba ................ 155

3.2.2.2. El perjuicio al Estatuto o al juicio.... 160

3.3. Casos de interceptaciones de comunicaciones en el desplazamiento forzado de Srebrenica .......... 164

3.3.1. Contexto grosso modo de Yugoslavia........... 165

3.3.2. Desplazamiento forzado de la ciudad de Srebrenica ................................................. 168

3.3.3. Apreciaciones del Tribunal sobre las interceptaciones de comunicaciones....... 174

Conclusiones: aplicación a los tres casos...................... 177 
Conclusiones generales ............................................................ 181

Tareas pendientes ……………………........................... 188

Referencias ....................................................................... 191

1. Artículos ............................................................. 191

2. Libros.............................................................. 191

3. Documentos internacionales .................................... 196

4. Legislación nacional ............................................... 197

5. Instrumentos internacionales .................................. 198

6. Jurisprudencia ............................................................. 199 

A mipadre

A todas aquellas personas gracias a quienes puedo narrar enseñanzas, anécdotas, e historias, que en conjunto, con lo bueno y lo malo, representan la mano de Dios.

En memoria de Winston Smith, Roger Casement, $y$ Josef $K$. 



\section{Siglas y abreviaturas}

art. / arts. Artículo/artículos
A. BiH
Ejército de Bosnia-Herzegovina
AUC
Autodefensas Unidas de Colombia
DutchBat Batallón Holandés

$\mathrm{CADH}$

Convención Americana de Derechos Humanos

$\mathrm{CIDH}$

Corte Interamericana de Derechos Humanos

$\mathrm{CEDH}$

Corte Europea de Derechos Humanos

CPI

Corte Penal Internacional

$\mathrm{CP}$

Código Penal

CPP

Código de Procedimiento Penal

CTI

Cuerpo Técnico de Investigación

DIDH

Derecho Internacional de los Derechos Humanos

DIH

Derecho Internacional Humanitario

ER

Estatuto de Roma

FARC Fuerzas Armadas Revolucionarias de Colombia

inc. Inciso

Lit. Literal

Mup Policía de República de Sprska

n. $\quad$ Nota al pie de página

num. Numeral

PIDCP Pacto Internacional de Derechos Civiles y Políticos RGT Reglamento concerniente a las leyes o costumbres de la Guerra Terrestre 


$\begin{array}{ll}\text { RIME } & \text { Regional de Inteligencia Militar del Ejército } \\ \text { RPP } & \text { Regla(s) de Procedimiento y Prueba } \\ \text { RS } & \text { República de Sprska } \\ \text { SIPOL } & \text { Seccional de Inteligencia Policial } \\ \text { TPIY } & \text { Tribunal Penal Internacional para la ex-Yugoslavia } \\ \text { TPIR } & \text { Tribunal Penal Internacional para Ruanda } \\ \text { UNHCR } & \text { Naciones Unidas para los Refugiados } \\ \text { UNPROFOR } & \text { Fuerzas de Protección de las Naciones Unidas } \\ \text { VRS } & \text { Ejército de la República de Sprska }\end{array}$




\section{Introducción Presentación de los tres casos}

Al estudiar la regla o cláusula de exclusión probatoria dentro del ordenamiento interno colombiano, se entiende que la regla general es la prohibición de aducir elementos de prueba que sean resultado de injerencias arbitrarias en la intimidad de las personas; por excepción, estas solamente se pueden practicar después de orden judicial, so pena de que los resultados sean excluidos del proceso. Sin embargo, encontramos que en la práctica hay casos que presentan un desarrollo diferente a lo que han venido planteando la legislación y la jurisprudencia nacional, y ello se ilustrará a través de tres casos de referencia.

En contraste, encontramos que la regla de exclusión ha tenido un tratamiento diferente a la luz del derecho internacional, principalmente en el derecho internacional humanitario, derecho internacional de los derechos humanos y el derecho internacional penal. Siendo así, la pregunta de investigación es la siguiente: ¿cuáles son las diferencias entre el derecho nacional y el derecho internacional sobre la regla de exclusión? La búsqueda de la respuesta nos impone revisar la consistencia de la posición de la Corte Constitucional cuando afirma que la regla que contiene el Estatuto 
de Roma es equiparable a la regla de exclusión nacional, según la Sentencia C-578 de 2002, que dice:

De este modo, todas las pruebas obtenidas como resultado de una violación del Estatuto o de las normas de derechos humanos internacionalmente reconocidas serán inadmisibles (regla de exclusión) cuando la violación suscite serias dudas sobre la fiabilidad de las pruebas o cuando su admisión atente "contra la integridad del juicio o redunde en grave desmedro de él”. Estas disposiciones coinciden con los principios establecidos en la Constitución colombiana, que también protegen la integridad del acervo probatorio y consagran la nulidad de las pruebas obtenidas con violación del debido proceso. ${ }^{1}$

Para llegar a la respuesta, este trabajo está estructurado en tres capítulos. En el primero, señalamos el estado del arte del derecho a la intimidad dentro del derecho doméstico colombiano, junto con la excepción de que la forma legal para realizar injerencias a este derecho implica una orden judicial previa; enseguida hacemos una breve exposición del procedimiento legal vigente para adelantar la interceptación de comunicaciones por parte de la Fiscalía General de la Nación, por considerarlo necesario como marco de referencia sobre la legalidad de los procedimientos internos; luego mostramos lo regulado para las actividades de inteligencia y contrainteligencia según la Ley 1621 de 2013;

\footnotetext{
1 Corte Constitucional, Sentencia C-578 de 2002.
} 
llegamos a una explicación del concepto de la prueba ilícita y sus excepciones, y terminamos mostrando los aportes y contrastes que se presentan en los casos de ejemplo.

En el segundo capítulo buscamos una posible solución según las herramientas que nos ofrecen los instrumentos internacionales. De este modo, comenzamos exponiendo el concepto de conflicto armado, entramos a explicar los principios del derecho internacional humanitario, cómo se podrían realizar lícitamente las injerencias en las comunicaciones a la luz de esta rama del derecho internacional. Después, entramos a estudiar el derecho Internacional de los derechos humanos en relación con la regla de exclusión en casos de injerencias en las comunicaciones. Este capítulo muestra de que manera los mismos tres casos de referencia podrían ser vistos a la luz de estas dos ramas del derecho internacional.

En el tercer capítulo entramos a revisar el derecho internacional penal, en el que encontramos la regla de exclusión dentro del Estatuto de Roma, que toma como base lo que se ha venido adelantando en los tribunales ad hoc, principalmente en el Tribunal Internacional para la ex-Yugoslavia y por la Corte Europea de Derechos Humanos. Enseguida exponemos el caso concreto del desplazamiento forzado de Srebrenica y cómo las interceptaciones de comunicaciones pudieron tener importancia allí, y terminamos señalando en los tres casos de referencia cómo podrían tener un tratamiento diferente.

Tras haber expuesto estos tres capítulos, concluiremos con la precisión de las diferencias que hay entre las reglas de 
exclusión, la del derecho nacional colombiano y la postura del derecho internacional en esta materia. Adicionalmente, hacemos apertura a algunas preguntas y tareas pendientes para adelantar investigaciones y acciones futuras.

Antes de entrar a exponer los tres casos de referencia, es importante señalar que estos no son de común ocurrencia. Son esporádicos pero casi siempre envuelven gran trascendencia política, lo cual contamina de ideología el estudio jurídico y generalmente obliga a largas demoras en su decisión. ${ }^{2}$ Por esa razón, con la intención de aterrizar las ideas que se expondrán en este documento, se procuró escoger tres casos que presentan menor carga política en estos tiempos, para con ellos ilustrar más pacíficamente tres tipos de eventualidades que se presentan en este campo, primero para identificar las injerencias en comunicaciones privadas, y segundo, para dirigir la atención a aquellas que tengan una relación con el conflicto armado interno. Desafortunadamente, por la escasez de casos con estas dos características, resultó necesario incluir el del coronel (r) Plazas Vega, por hechos de 1985 que siguen siendo sensibles en la actualidad.

El primero de ellos trata de interceptaciones por la Regional de Inteligencia Militar del Ejército (RIME); el segundo caso es de captaciones incidentales que obtuvo la oficina Seccional de Inteligencia Policial (SIPOL); y el terce-

2 Por ejemplo, en el gobierno de Álvaro Uribe, hacia 2006 se presentaron interceptaciones de comunicaciones que han llevado a condenas de altos funcionarios del Estado colombiano solo en 2014, y otras varias continúan. En la campaña política de 2014 se presentaron otros casos, cuya judicialización ha seguido un tortuoso camino y aún no produce resultados en firme. 
ro, como se había señalado, son grabaciones en el espectro electromagnético por personas particulares en la toma del Palacio de Justicia.

\section{El caso de Juan Carlos Castillo por concierto} para delinquir, tráfico y porte de armas de defensa personal y tráfico de armas de uso privativo de las fuerzas armadas ${ }^{3}$

El sargento Segundo Juan Carlos Castillo, para el año 2004, traficaba armamento tanto de uso personal como de uso privativo del ejército, para grupos criminales como las autodefensas, el Frente 16 de las farc (Fuerzas Armadas Revolucionarias de Colombia) y bandas de delincuencia común, en las ciudades de Bogotá, Villavicencio, Yopal y San Vicente del Caguán. Se debe tener en cuenta que Castillo era miembro del Ejército Nacional en el Batallón Cazadores, acantonado en San Vicente del Caguán. Este proceso cuenta con otras dos personas que fueron condenadas por sentencia anticipada, y otras tres personas a quienes se les llevó a proceso penal ordinario.

Originalmente, miembros del Cuerpo Técnico de Investigación (CTI), tras autorización del fiscal delegado, hacen la interceptación de diferentes números telefónicos. Sin embargo, encuentran que algunos ya habían sido intercep-

3 Tribunal Superior del Distrito Judicial de Bogotá, Rad. $110010704002-$ 2007-00056-01 (09-10), Sentencia del 25 de mayo de 2011. Si bien hay decisión de la Corte Suprema de Justicia-Sala de Casación Penal, Rad. 37.365, Auto de 21 de noviembre de 2011, en esta decisión no estudia de fondo el caso, sino que hace referencia a la ineptitud de la demanda que lleva a su inadmisión. 
tados por Inteligencia Militar, en concreto por la RIME 4. Así, la investigación se estaba llevando de manera conjunta entre la RIME 4 y 5 con el CTI; se demuestra que el CTI no pudo hacer algunas interceptaciones porque algunas líneas telefónicas ya estaban interceptadas por la Inteligencia Militar, y si bien el CTI pudo adelantar labores con otras líneas, tuvo que redireccionar los actos de investigación por estos inconvenientes, y aun así volvió a encontrar que otras líneas también lo estaban. Aquí vemos que, principalmente la RIME 4, no desarrollaba una actividad de monitoreo, sino de interceptación de comunicaciones propiamente dicha, en cuanto hace seguimiento de números telefónicos específicos.

En este caso, las interceptaciones efectuadas por personal del CTI estuvieron conformes con la Ley 600, por lo tanto no afectó indebidamente los derechos del procesado. Ahora, si bien es cierto que el Tribunal considera que las interceptaciones del Ejército fueron ilícitas, la información obtenida sirvió para orientar la indagación en el momento de la noticia criminis. Según el Tribunal, los allanamientos y las interceptaciones realizadas propiamente por el CTI no tenían relación directa con las labores de Inteligencia Militar. Por tal razón, se consideró que había un vínculo atenuado entre las actividades de la RIME con las labores del CTI. Así, las pruebas obtenidas con orden de la Fiscalía se mantienen en el proceso, pero los informes de Inteligencia Militar son excluidos porque no tenía funciones de policía judicial.

Finalmente, a partir del análisis en conjunto del material probatorio, incluidas las interceptaciones, se consigue demostrar que el papel de Juan Carlos Castillo, en cuanto era 
una de las personas encargadas de conseguir el armamento y las piezas que se fuese a traficar, fue una persona clave para que se cometieran los tipos penales endilgados. Resaltamos que este tráfico de armamento tiene una relación con el conflicto armado vigente porque se entregaba a sujetos activos del conflicto como son las FARC o las autodefensas.

\section{El caso de la masacre de Macayepo}

El 10 de julio de 2007 la Corte Suprema de Justicia expidió auto de acusación ${ }^{4}$ contra el entonces senador Álvaro Alfonso García Romero y el representante a la Cámara Érick Julio Morris Taboada, con el Rad. 26.116, donde se judicializa: el homicidio de Georgina Narváez en San Onofre-Sucre, el 19 de noviembre de 1997; la utilización de recursos públicos para la constitución del Frente "La Mojana" de las Autodefensas Unidas de Colombia (AUC), por un contrato estatal del 4 de noviembre de 1998; y, los hechos por los que se conoce este caso, la masacre en el corregimiento de Macayepo, Carmen de Bolívar-Bolívar, el 16 de octubre de 2000, donde se cometieron numerosos homicidios que provocaron un desplazamiento forzado masivo. Este es uno de los casos más emblemáticos de lo que se conoce como "parapolítica”.

4 Corte Suprema de Justicia-Sala de Casación Penal, Rad. 26.118, Auto de Acusación de 10 de julio de 2007. En este caso estuvo originalmente también vinculado Jairo Enrique Merlano Fernández, pero tras su renuncia a su investidura, la Corte consideró que perdió el fuero constitucional y por tanto se adelantó como un proceso ordinario. 
Con Auto del 10 de julio de 2007, se acusó a García Romero como determinador del concurso homogéneo de homicidio agravado por las víctimas de la masacre de Macayepo, por el homicidio simple de la señora Georgina Narváez, y del delito de peculado por apropiación, y autor del delito de concierto para delinquir agravado; a Morris Taboada se le acusó como autor de concierto para delinquir agravado. ${ }^{5}$ En este auto de acusación, las interceptaciones de comunicaciones sirvieron como elemento material probatorio para endilgar responsabilidad a García Romero por la masacre. La SIPOL captó incidentalmente una conversación telefónica del 7 de octubre de 2000 entre García Romero, Joaquín García Rodríguez y otro funcionario, de donde se concluye que en esta conversación se busca primero, el movimiento de infantes de marina para que recojan un gran número de vacunos que fueron robados por grupos guerrilleros; segundo, buscar el traslado del comandante de la Policía en el departamento de Sucre, Rodolfo Palomino López, porque era un obstáculo para la actuación de grupos paramilitares; y finalmente, se evidencia el desplazamiento de un grupo de paramilitares desde el golfo de Morrosquillo hasta el corregimiento de Macayepo. ${ }^{6}$

5 Es importante aclarar que hubo una ruptura de unidad procesal, por la que el representante Morris Taboada siguió con el número de original de radicado, y el caso Álvaro Alfonso García Romero terminó con la sentencia de 23 de febrero de 2010, Rad. 32.805.

6 Corte Suprema de Justicia-Sala de Casación Penal, Rad. 26.118, Auto de Acusación de 10 de julio de 2007. 
La Corte consideró que esta interceptación por la Policía Nacional era lícita porque se dio dentro del monitoreo del espectro electromagnético, obteniendo la señal de manera incidental. Este monitoreo, considera la Sala, es un procedimiento usual dentro de las actividades de inteligencia, y se hace con el fin de prevenir y contrarrestar acciones delincuenciales. Seguidamente, la Corte distingue las actividades que desarrollan los cuerpos de inteligencia, de las actividades de "interceptación de comunicaciones" que están sujetas a reserva judicial. El principal criterio diferenciador es que la actividad de inteligencia se ampara bajo el art. 218 constitucional en concordancia con el art. $75 \mathrm{ib}$., por el cual la Policía tiene "como fin primordial el mantenimiento de las condiciones necesarias para el ejercicio de los derechos y libertades públicas y para asegurar que los habitantes de Colombia vivan en paz", 7 y por tanto, le es permitido adelantar todas las actividades necesarias para prevenir la comisión de delitos, siempre y cuando se adelanten como un rastreo indeterminado y se hagan captaciones accidentales de comunicaciones. Situación diferente, según la Corte, a las actividades que desarrollan "los órganos de la jurisdicción penal y los cuerpos de policía judicial que le sirven de apoyo cuyo objeto, en cambio, se encamina a sancionar a los responsables de la ejecución de conductas punibles en particular". ${ }^{8}$ Siendo así, considera que no es reprochable la captación incidental de un diálogo privado, por un rastreo

\footnotetext{
7 Ídem.

8 Ídem.
} 
indeterminado que adelantaba la siPOL del departamento de Sucre.

Como se sabe, la masacre de Macayepo en efecto sucedió. No se previno poniéndola en conocimiento de las autoridades judiciales, según el deber legal de denunciar la comisión de un delito que se haya conocido "por cualquier medio", 9 como ordena el art. 25 del Decreto 2700 de 1991, CPP vigente para la época de los hechos. Seguidamente, la Corte explica que si bien el informe que se presenta por la actividad de inteligencia no sirve como prueba de los hechos directamente, sí sirve como un criterio orientador de la investigación, en regla con el art. 314 de la Ley 600 (Labores previas de verificación). Dice la Corte:

Es deber de la autoridad de inteligencia en esos casos, por lo tanto, trasladar esa información sin demora a la autoridad judicial competente a través del respectivo informe, que al igual que los de Policía Judicial sólo podrá servir como criterio orientador de la investigación y en ningún caso como evidencia de la responsabilidad penal de quienes resulten implicados en virtud del producto de inteligencia. ${ }^{10}$

Haciendo las anteriores declaraciones, la Corte respondió al Ministerio Público que no hubo una vulneración del derecho a la intimidad, considerando, primero, que no hay

9 Ídem.

10 Ídem. 
derechos absolutos y sus límites se encuentran en los derechos de los demás; y segundo, que es un rastreo indeterminado y no interceptación de manera particular; y tercero, la Corte considera que es "absurdo despojar a las autoridades de un elemento adecuado para la lucha contra el crimen desde el punto de vista preventivo". ${ }^{11,12}$

Después, tras la ruptura de la unidad procesal, se adelantó el proceso solamente contra el representante a la Cámara Érick Julio Morris Taboada (con el mismo radicado 26.118); se dictó sentencia el 19 de diciembre de 2007, condenándosele por concierto para delinquir agravado bajo el título de autor. En este caso, se consideró en los hechos que la conversación entre el senador García Romero y Joaquín García Rodríguez hacían referencia a Morris Taboada, de donde se infiere habían hecho acuerdos ilícitos previos. ${ }^{13}$

Posteriormente la Corte Suprema de Justicia sentenció al senador Álvaro García Romero, con Rad. 32.805 del 23 de febrero de 2010, como autor de concierto para delinquir, determinador del homicidio Georgina Narváez y peculado

11 Ídem.

12 Sin embargo, la Corte después de darle contestación al Ministerio Público, dijo: “Tampoco se desecha que esa línea y todo el diálogo siguiente corresponda a una segunda llamada telefónica”. En este orden de ideas, cuando se demuestra que hay una segunda llamada interceptada se le resta credibilidad a que se haya hecho un rastreo indeterminado. Sin embargo, dijo bien la Corte que la conversación no pudo ser tan distante ni con tantas personas, como responde posteriormente a uno de los abogados defensores. Seguidamente, en la Sentencia Rad. 32.805, en la práctica probatoria no se logró desvirtuar la autenticidad de la grabación.

13 Corte Suprema de Justicia-Sala de Casación Penal, Rad. 26.118, Sentencia de 19 de diciembre de 2007. 
por apropiación, y como autor mediato en aparatos organizados de poder por la masacre de Macayepo. En este caso la defensa se enfocó en atacar la legalidad y autenticidad de las grabaciones; sin embargo, los intentos de la defensa fueron fallidos en cuanto que la Sala confirmó lo ya expuesto por el auto de acusación, y la práctica probatoria demostró que el documento era auténtico. Ahora, es importante resaltar que a pesar de que en el auto se dijo que no podría tener valor probatorio, se le trató como una prueba documental, y el testigo de acreditación termina siendo experto en esta materia para demostrar su autenticidad. Esta prueba hace que la Corte concluya lo siguiente:

En suma, encuentra la Sala que el contenido de la conversación, aunado a la información que allí se le suministró y las gestiones que le fueron encomendadas a GARCíA ROMERO, como el decurso posterior de los acontecimientos, resultan claramente indicativos de cómo el procesado no sólo organizó el grupo de autodefensas autor de la masacre, sino que además desarrolló comportamientos propios de un miembro de ese tipo de agrupaciones armadas ilegales, todo lo cual permite reprocharle a título de autor mediato los múltiples homicidios acaecidos en desarrollo de dicha incursión paramilitar ${ }^{14}$ (cursivas fuera del texto).

14 Corte Suprema de Justicia-Sala de Casación Penal, Rad. 32.805, Sentencia de 23 de febrero de 2010. 


\section{El caso del coronel Alfonso Plazas Vega y la toma al Palacio de Justicia}

Los días 6 y 7 de noviembre de 1985 se produjo lo que se conoce como la toma al Palacio de Justicia en Bogotá por el grupo subversivo M-19. En el proceso contra el coronel (r) Alfonso Plazas Vega, se lo condenó en primera instancia por la desaparición forzada de once personas. ${ }^{15}$ Después el Tribunal Superior de Bogotá, conociendo del recurso de apelación, confirma la condena pero solo por la desaparición de dos personas (la guerrillera Irma Franco Pineda y el administrador de la cafetería Carlos Augusto Rodríguez Vera). ${ }^{16}$

En este caso se presentaron las grabaciones de la interceptación de comunicaciones, que sirvieron para demostrar cómo se desarrolló la coordinación de las diferentes acciones por parte de la Brigada XIII. Las diferentes comunicaciones de los miembros de esta brigada se dieron mediante frecuencias abiertas, que fueron interceptadas por radioaficionados, ciudadanos particulares que no participaban en el combate. También se utilizaron frecuencias privadas que eran exclusivas de las fuerzas militares y de ellas no se tiene noticia. Esto se debe a que para la época se utilizaban dos tipos de

15 Las once víctimas alegadas son Carlos Augusto Rodríguez Vera, Cristina del Pilar Guarín Cortés, Bernardo Beltrán Hernández, David Suspes Celis, Gloria Stella Lizarazo Figueroa, Gloria Anzola de Lanao, Norma Constanza Esguerra, Luz Mary Portela León, Irma Franco Pineda, Héctor Jaime Beltrán Fuentes y Lucy Amparo Oviedo. Cfr., Juzgado Tercero Penal del Circuito Especializado de Bogotá, Rad. 1100113207003-2008-00025-00, Sentencia de 9 de junio de 2010.

16 Tribunal Superior del Distrito Judicial de Bogotá, Sentencia del 30 de enero de 2012, Rad. 110010704003-2008-00025-09. 
radios, unos de tipo Motorola que se podían interceptar, y otros que no, los PRC77. ${ }^{17}$

La Sala de decisión del Tribunal Superior de Bogotá considera que las grabaciones revelan cómo se enfrentaron los militares a la acción del grupo guerrillero M-19. A partir de ellas, demuestra que de manera clara e inequívoca se impartieron diferentes órdenes, entre ellas algunas ilegales, con fines de "supresión física de los rebeldes, [...] la realidad es que no les importaban los rehenes y menos los rebeldes, a quienes se referían como a los que había que 'fumigar'”. ${ }^{18}$ De igual forma, se encuentran dentro de la conversación grabada varias instrucciones que, gracias al trabajo pericial que hizo la Policía Nacional, se considera que algunas van en contra de la Constitución, de instrumentos internacionales y la Ley penal, señalando principalmente la siguiente:

ARCANO 5: R, eh... ya sabe... las instrucciones complementarias a estos son terminantes, cambio.

ARCANO 2: Ah, recibido y QSL, recibido y QSL Arcano Cinco. 145

17 Juzgado Tercero Penal del Circuito Especializado, Sentencia del 9 de junio de 2010, Rad. 1100113207003-2008-00025-00, en el apartado referente a las comunicaciones.

18 Tribunal Superior de Bogotá, Rad. 110010704003-2008-00025-09, Sentencia del 30 de enero de 2012, en el apartado de las grabación de las comunicaciones militares. 


\section{y un poco después:}

ARCANo 5: R, está QSL ¿̇y el... el seis, uno de los seis de estos sujetos eh...?, cambio.

ARCANO 2: No, negativo, únicamente pudimos obtener inclinación sobre una sujeto, sobre una sujeto que es abogada, y que ya fue reconocida por todo el personal, cambio.

ARCANO 5: Esperamos que si está la manga no aparezca el chaleco, cambio.

ARCANO 2: Recibido, QSL. ${ }^{19}$ (cursivas fuera de texto)

Así, las grabaciones sirven como prueba para demostrar que las acciones de las fuerzas militares son ilícitas. Con esto, después el Tribunal entra a examinar la autoría mediata de la desaparición forzada, por el coronel (r) Plazas Vega, en aparatos organizados de poder.

Estas grabaciones llegaron a través de los particulares Pablo Montaña y Mike Forero Nougés, actuando como radioaficionados, quienes se las aportaron a Herbin Hoyos y Ramón Jimeno, periodistas de Radio Todelar. La Sala las considera fidedignas en cuanto se satisface la explicación de cómo se obtuvieron, la relación entre la duración del operativo y el tiempo total de las grabaciones, así como los saltos de las conversaciones, y se concluye que estas conversaciones se dieron durante el operativo. Por tanto, la Sala utiliza esta prueba documental dentro de su providencia porque fue

19 Ídem. 
aducida legalmente y contrastada con todo el acervo probatorio. Después de tratar la autenticidad de la prueba entra a analizar el derecho a la intimidad diciendo lo siguiente:

Si bien es cierto que los agentes estatales en el ejercicio de sus funciones tienen derecho a la intimidad, y con ello al secreto de las comunicaciones, de modo que no es lícito que se les intercepte cuando cumplen sus funciones constitucionales y legales, si un servidor público desborda el marco legal y utiliza medios institucionales para la comisión de delitos de lesa humanidad, y, por ejemplo, si sus conversaciones son escuchadas o grabadas por cualquier persona y éste (sic) las aporta a un proceso, las acciones del buen ciudadano no puede ser objeto de persecución penal y el documento (la grabación) podrá ser valorado probatoriamente dentro la respectiva actuación. Esto es así porque cuando un agente estatal utiliza las herramientas que le ha entregado el Estado para el cumplimiento de sus actividades, tiene la obligación de darles un fin lícito y no podrá ampararse en que su derecho a la intimidad se vulnera cuando utiliza los medios estatales con el propósito de cometer delitos de lesa humanidad. ${ }^{20}$

Aquí encontramos un análisis donde se considera proporcional la interceptación de un ciudadano particular a una conversación de agentes estatales, siendo válido solo en cuanto las actuaciones de estos desbordan el marco legal.

20 Ídem. 
Además, considera, primero, que no es el mismo derecho de la intimidad cuando se presenta por los mandos militares dentro de una operación, que el derecho a la intimidad que alegan los particulares frente al Estado; y segundo, que las conversaciones no tienen ningún contenido de información personal, sino que tratan de órdenes militares, ni versan sobre temas de seguridad nacional, ni secretos de Estado; tercero, las conversaciones que se presentaron en los miembros de la fuerza pública no tenían la expectativa de ser privadas en cuanto podían ser escuchadas por cualquier radioaficionado, y se muestra que cuando se querían realizar comunicaciones reservadas, se hacía a través de lo que llamaban la línea 500 o "la misteriosa". Por lo anterior, considera la Sala mayoritaria que estas grabaciones de conversaciones interceptadas son lícitas.

Sin embargo, en el salvamento de voto hay un análisis por el cual se termina cuestionando la originalidad y autenticidad de las grabaciones en cuanto estas fueron editadas, dado que no hay una continuidad coherente de la grabación; tampoco se puede tener seguridad de quiénes son los sujetos que conversan, y finalmente hay divergencias entre las grabaciones y las declaraciones que las sustentan. Por otra parte, considera que estas grabaciones son ilícitas, puesto que no están acordes a lo reglamentado por el Ministerio de Comunicaciones en el Decreto 1554 del 5 de junio de 1985, como se puede ilustrar cuando le responde al señor Montaña de la siguiente manera: 
El señor Montaña se introdujo en frecuencias no autorizadas para él como radioaficionado, con el fin de conocer lo que sucedía en ese momento en el Palacio de Justicia. Ello es así, según se verifica, porque la frecuencia en la que dice pudo captar dichas comunicaciones - 155 o 156 Mhz - está dentro del rango del equipo escáner con el que realizó tal maniobra - de 138 a $164 \mathrm{Mhz}$-, pero, no dentro de la franja de frecuencias en las que legalmente podía moverse, y a las que tenía autorización legal para acceder como radioaficionado. Baste repasar el Decreto 1554 del 5 de junio de 1985 para constatar lo afirmado. ${ }^{21}$

Expuestos los tres casos de referencia, afrontamos el plan anunciado.

21 Tribunal Superior del Distrito Judicial Bogotá, Rad. 1100107040032008-00025-09. Aclaración y salvamento de voto de la Sentencia de 30 de enero de 2012. 


\section{Capítulo primero \\ Exclusión probatoria por injerencias al derecho a la intimidad en el derecho colombiano}

\section{Introducción}

Este capítulo tiene por fin describir el marco del derecho a la intimidad y su relación con el debido proceso. Después nos concentraremos en el proceso penal colombiano, principalmente con las interceptaciones de comunicaciones, y la regla de exclusión. Finalmente, expondremos tres casos que se presentaron en el sistema nacional colombiano, los que muestran una tensión de estos con el marco previamente construido.

\subsection{Derecho a la intimidad y su relación con la interceptación de comunicaciones}

\subsubsection{Fundamentos de protección de la intimidad como expresión de la dignidad humana \\ La actual forma de organización política de Colombia es la del Estado social de derecho. Esto hace que se adicionen al Estado de derecho los tres siguientes componentes:}


(1) La dimensión de la vinculación Social del Estado, que implica la obligación de los poderes públicos de velar por la previsión, distribución e igualación de los bienes materiales y de cultura; (2) La dimensión de la referencia social de los derechos fundamentales, que impone la obligación de interpretar estos derechos, desde el principio de garantía de la libertad; (3) La dimensión de la obligación del Estado de articular la sociedad desde bases democráticas ${ }^{1}$ (numerales fuera de texto original).

También se entiende por Estado social de derecho aquel "[e]stado construido sobre un principio estructural complejo, por ser principio de principios, cuya esencia radica en que su contenido y alcance deriva de la recíproca interacción de los valores de la democracia, lo social y la idea del Estado de Derecho en sentido material". ${ }^{2}$

Desde este punto de vista, el Estado se funda en el respeto de la dignidad humana, entendido según el segundo imperativo categórico de Kant: "Obra de tal modo que uses la humanidad, tanto en tu persona como en la persona de cualquier otro, siempre como un fin al mismo tiempo y nunca solamente como un medio". ${ }^{3}$ Sobre esto la Corte Constitucional dice que "La dignidad humana es el valor

\footnotetext{
1 Quinche Ramírez, Manuel Fernando. Derecho Constitucional Colom-

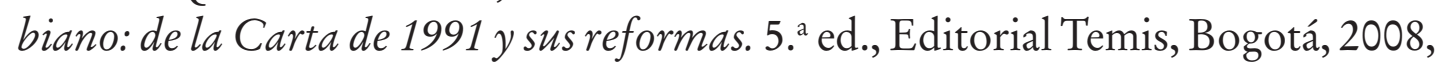
p. 49.

2 Ibíd., p. 49, citando a: Parejo, Luciano. Estado social y administración pública. Editorial Civitas, Madrid, 1983.

3 Corte Constitucional, Sentencia T-211 de 1994, citando a: Kant, Inma-
} 
supremo del Estado Social de Derecho". ${ }^{4}$ Asimismo, tanto la Corte Suprema de Justicia, Sala de Casación Penal, como la Corte Constitucional han entendido que la dignidad humana es uno de los pilares del Estado colombiano y se ha entendido en tres aspectos: “(i) es un principio fundante del ordenamiento jurídico y en este sentido tiene una dimensión axiológica como valor constitucional, (ii) es un principio constitucional y (iii) tiene el carácter de derecho fundamental autónomo". ${ }^{5}$

Entender a una persona como un fin en sí mismo implica también que la persona es libre, es decir, que tiene la capacidad de autogobernarse ${ }^{6}$ indica que la dignidad se relaciona directamente con la libertad de la persona. Tanto la libertad como la dignidad son consideradas como principios constitucionales, entendiendo "principios" como "normas que [ordenan] algo [y que] sea realizado en la mayor medida posible dentro de las posibilidades jurídicas y reales existentes; [p]or mandatos de optimización, que están ca-

nuel. Fundamentos de la metafísica de las costumbres. Edit. Porrúa S.A., México, 1990, pág. 44.

4 Quinche Ramírez, Manuel Fernando. Op. cit., p. 75, citando a: Corte Constitucional, Sentencia C-414 de 1992.

5 Corte Suprema de Justicia-Sala de Casación Penal, Sentencia Rad. 33.621, Sentencia de 10 de marzo de 2010, citando Corte Constitucional, Sentencia C-355 de 2006. Ver Corte Constitucional, Sentencia T-881 de 2002, en la cual se hace un exhaustivo recuento de los alcances funcionales y normativos del concepto dignidad humana.

6 Rojas Gómez, Miguel Enrique. Eficacia de la prueba obtenida mediante irrupción en la intimidad. Universidad Externado de Colombia, Bogotá, 2011, p. 28. 
racterizados por el hecho de que pueden ser cumplidos en diferente grado"? Además, son "normas que condicionan las demás normas, pero con mayor grado de concreción y por lo tanto de eficacia, alcanzando por sí mismo proyección normativa", precisando que son "dotadas de toda fuerza normativa, de aplicación inmediata, tanto por el legislador como por el juez". P Por ello “[e]l sujeto razón y fin de la Constitución de 1991 es la persona humana, no es pues el individuo en abstracto, aisladamente considerado, sino precisamente el ser humano en su dimensión social, visto en la tensión individuo-comunidad, la razón última de la nueva carta Política”. ${ }^{10}$ Estos principios irradian el art. $10^{\circ}$ del Código Penal vigente que dice: "El derecho penal tendrá como fundamento el respeto a la dignidad humana”. De igual forma en el art. $1^{\circ}$ del Código de Procedimiento Penal, Ley 906, dice: "Los intervinientes en el proceso penal serán tratados con el respeto debido a la dignidad humana”.

El derecho a la intimidad, reconocido en el art. 15 constitucional, se encuentra relacionado precisamente con el principio de dignidad, siendo este base para el tipo de Estado vigente. La Corte Constitucional, siguiendo a Schneider, afirma que “el Estado debe 'asegurar' a la persona un ámbito de libertad en el que desarrolle espontáneamente su

7 Quinche Ramírez, Manuel Fernando. Op. cit., p. 64, citando a: Alexy, Robert. Teoría de los derechos fundamentales. Centro de Estudios Constitucionales, Madrid, 1983.

$8 \quad$ Ibíd., p. 68, citando a: Corte Constitucional, Sentencia C-1287 de 2001.

$9 \quad$ Ibíd., p. 68.

10 Corte Constitucional, Sentencia T-011 de 1992. 
personalidad y en el que podrán refugiarse discreta e incontroladamente y donde gozarán el derecho a la 'intimidad', expresión de su dignidad humana" ${ }^{11}$ Esa relación se da porque una vigilancia no deseada impide a la persona realizar todas aquellas conductas que realizaría en su intimidad o privacidad. ${ }^{12}$ En este orden de ideas, la intimidad tiene una relación directa con la libertad y la dignidad de la persona, y por tanto se puede identificar como un valor y un principio constitucional que irradia otras normas jurídicas.

Hay diferentes formas de proteger derechos o principios constitucionales; uno de los medios para ello es tratarlos como bienes jurídicos, como es el caso del derecho a la intimidad. Por ello el legislador decide protegerlos a partir del desarrollo normativo penal en diferentes formas, no solo a través de la consagración de tipos penales, sino también con la regulación de la cláusula o regla de exclusión de la prueba obtenida con violación de este derecho. ${ }^{13} \mathrm{Un}$ caso de lo anterior es lo relacionado con la interceptación de comunicaciones; esta se encuentra regulada como tipo penal en el art. 169 del Código de Penal (CP) con el nombre "violación ilícita de comunicaciones". Adicionalmente,

11 Corte Constitucional, Sentencia T-011 de 1992, citando a: Schneider, Hans Peter. Democracia y Constitución. Centro de Estudios Constitucionales, Madrid, 1991, p. 21; Cfr., Corte Constitucional, Sentencia T-414 de 1992.

12 Rojas Gómez, Miguel Enrique. Op. cit., pp. 29, 30.

13 Cfr., Von Hirsh, Andrew. El concepto de bien jurídico y el "principio de daño". En: Hefendehl, Roland (Edit.). La teoría del bien jurídico. ¿Fundamento de legitimación de derecho penal o juego de abolorios dogmático? Editorial Marcial Pons, Madrid, 2007. 
encontramos la regulación para la producción de la prueba en el Código de Procedimiento Penal (CPP) en el art. 235, de manera que si la interceptación no está en regla con este artículo, se ordena la exclusión probatoria en cumplimiento del art. 23 del mismo. Vemos entonces cómo el derecho a la intimidad, en estos casos, se puede ver como bien jurídico tutelable que se protege a partir de la configuración de tipos penales, pero también con la inadmisibilidad, o en su defecto la exclusión, de material probatorio que se produjo a partir de la injerencia indebida en la intimidad de las personas.

La relación que hay entre el proceso penal y la dignidad humana se concreta en un punto preciso: el afán por obtener la verdad real o sustancial. Como bien dice Urbano Martínez: “[e]n tal contexto, la búsqueda de la verdad histórica dentro de un proceso, si bien sigue siendo el presupuesto para la emisión de una decisión justa, ya no es algo que se puede conseguir a cualquier precio, pues en su búsqueda se deben respetar unas barreras que al poder político le resultan infranqueables" 14 . Este es un punto que se viene desarrollando desde 1906 por Ernst Beling cuando dice: "Habrá completo acuerdo acerca del principio de que también el proceso penal debe respetar la dignidad bumana y en consecuencia un conflicto insoluble entre la dignidad

14 Urbano Martínez, José Joaquín. Prueba ilícita y regla de exclusión. En: Uprimny, Rodrigo y otros. Reflexiones sobre el nuevo sistema procesal penal. Instituto de Estudios del Ministerio Público. 2. a ed, Bogotá, 2006, p. 269. 
humana e intereses del proceso penal tiene que conllevar una prohibición probatoria”. ${ }^{15}$

\subsubsection{La protección de las comunicaciones como una manifestación del derecho a la intimidad} Partimos del significado de la palabra "intimidad": la Real Academia de la Lengua Española la entiende, en su segunda acepción, como la " [z]ona espiritual íntima y reservada de una persona o de un grupo, especialmente de una familia". ${ }^{16}$ El derecho a la intimidad se relaciona con la privacidad de la persona, y esta se entiende como "[á]mbito de la vida privada que se tiene derecho a proteger de cualquier intromisión". ${ }^{17}$ Siendo así, entendemos la intimidad como el espacio donde se desarrolla la vida privada, ya sea de una persona o un grupo, y por tanto es de carácter reservado y libre de intromisión alguna.

Dentro del marco nacional, el derecho a la intimidad lo encontramos expresamente en el art. 15. Este reza:

Artículo 15. Todas las personas tienen derecho a su intimidad personal y familiar y a su buen nombre, y el Estado debe respetarlos y hacerlos respetar. De igual

15 Beling, Ernst. Las probibiciones de prueba como limite a la averiguación de la verdad en el proceso penal. En: Beling, Ernst y otros. Las probibiciones probatorias. Editorial Temis S.A, Bogotá, 2009, p. 52.

16 Diccionario de la Real Academia de la Lengua Española, revisado el 4 de agosto de 2013, en: http://lema.rae.es/drae/?val=intimidad.

17 Diccionario de la Real Academia de la Lengua Española, revisado el 4 de agosto de 2013, en: http://lema.rae.es/drae/?val=privacidad. 
modo, tienen derecho a conocer, actualizar y rectificar las informaciones que se hayan recogido sobre ellas en bancos de datos y en archivos de entidades públicas y privadas.

En la recolección, tratamiento y circulación de datos se respetarán la libertad y demás garantías consagradas en la Constitución.

La correspondencia y demás formas de comunicación privada son inviolables. Sólo pueden ser interceptadas o registradas mediante orden judicial, en los casos y con las formalidades que establezca la ley.

Para efectos tributarios o judiciales y para los casos de inspección, vigilancia e intervención del Estado podrá exigirse la presentación de libros de contabilidad y demás documentos privados, en los términos que señale la ley ${ }^{18}$ (cursivas fuera del texto).

Este derecho si bien tiene una primera manifestación en la Primera Enmienda a la Constitución de los Estados Unidos cuando trata el derecho a la intimidad religiosa, el derecho a la intimidad como tal "adquiere identidad definitiva en 1890, en los Estados Unidos, cuando Warren y Brandeis elaboran el 'Right of Privacity'; posteriormente en fallo de 1965 de la Corte Suprema de los Estados Unidos, en el caso Griswald vs. Connecticut, le confiere los alcances definitivos

18 República de Colombia, Constitución Política de Colombia, publicada en Gaceta Constitucional n. ${ }^{\circ} 116$ de 20 de julio de 1991, art. 15. 
que actualmente posee este derecho". ${ }^{19}$ Basándose en esto, la Corte Constitucional colombiana adopta y desarrolla la dicotomía entre lo "público" y lo "privado". ${ }^{20}$

Esta norma no es nueva en el sistema jurídico nacional. La prohibición estaba regulada en el art. 59-1 de la Constitución de 1858, en el art. 15 de la Constitución de 1863, y en la Carta de 1886, en su art. 38. ${ }^{21}$ Actualmente, la Corte Constitucional entiende que "La vida privada, al sentir de Novoa Monreal, 'está constituida por aquellos fenómenos, comportamientos, datos y situaciones de una persona que normalmente están sustraídos al conocimiento de extraños y cuyo conocimiento por éstos puede turbarla moralmente por afectar su pudor o su recato a menos que esa misma persona asienta a ese conocimiento'". ${ }^{22}$ Con ello, se entiende por intimidad personal el "área restringida inherente a toda persona o familia, que solamente puede ser penetrada por extraños con el consentimiento de su titular o mediando orden dictada por autoridad competente, en ejercicio de sus funciones y de conformidad con la Constitución y la ley". ${ }^{23}$ Es importante distinguir que la Constitución vigen-

19 Corte Constitucional, Sentencia T-011 de 1992; Cfr., Escobar López, Édgar; Marulanda Otálvaro, Luz Fabiola. El derecho a la Intimidad. 2. a ed, Ediciones Doctrina y Ley, Bogotá, 2004.

20 Corte Constitucional, Sentencia T-787 de 2004.

21 Corte Constitucional, Sentencia T-349 de 1993.

22 Corte Constitucional, Sentencia T-011 de 1992, citando a: Novoa Monreal, Eduardo. Derecho a la vida privada y libertad de información. Un conflicto de derechos. Ediciones Siglo XXI, México, 1989, p. 87 y ss; Cfr., Corte Constitucional, T-787 de 2004.

23 Corte Constitucional, Sentencia T-233 de 2007, citando a: Corte 
te abarca diferentes rangos de intimidad, como es el caso de la inviolabilidad del domicilio en el art. 28, registros de información personal, es decir el habeas data en el art. 15 inc. 1, y la prohibición de interceptación de comunicaciones en el inciso 2 del mismo artículo. Siendo así, en ellos nos concentraremos en la interceptación de comunicaciones.

Édgar Escobar López y Luz Fabiola Marulanda entienden que el derecho a la intimidad está compuesto por tres aspectos: la tranquilidad, la autonomía y el control de información. ${ }^{24}$ La tranquilidad de la persona se entiende - citando a Novoa Montreal - como "el derecho que tiene todo ser humano a disponer de momentos de soledad, recogimiento y quietud que le permite replegarse sobre sí mismo". ${ }^{25}$ En relación con la autonomía, “[e]l derecho al respeto de la vida privada consiste esencialmente en poder conducir su

Constitucional, Sentencia T-696 de 1996; Cfr., Corte Constitucional, Sentencia T-787 de 2004 al decir: "el núcleo esencial del derecho a la intimidad, supone la existencia y goce de una órbita reservada en cada persona, exenta del poder de intervención del Estado o de las intromisiones arbitrarias de la sociedad, que le permita a dicho individuo el pleno desarrollo de su vida personal, espiritual y cultural"; Cfr., CIDH, Caso Escher y otros v. Brasil. Sentencia de 6 de julio de 2009, párr. 113; y Caso Tristán Donoso v. Panamá. Sentencia de 27 de enero de 2009, párr. 55; Naciones Unidas, Comité de Derechos Humanos, Observación General n. ${ }^{\circ}$ 16, Article 17 (The right to respect of privacy, family, home and correspondence, and protection of honour and reputation) HRI/GEN/1/Rev.7 at 162 de 28 de septiembre de 1988, párr. 3.

24 Escobar López, Édgar y Marulanda Otálvaro, Luz Fabiola. Op. cit., p. 39 .

25 Ibíd., p. 39, citando a: Novoa Montreal, Eduardo. Derecho a la vida privada y libertad de información. Un conflicto de intereses. Ediciones Siglo XXI, México, p. 96. 
vida como uno pretenda, con un mínimo de injerencias”. ${ }^{26} \mathrm{Y}$ el tercer aspecto, el control de información, "[l]a Intimidad o privacidad, con respecto a la información, se manifiesta en dos direcciones: una, la posibilidad de mantener ocultos o reservados ciertos aspectos de la vida de las personas; de otro lado, la posibilidad que corresponde a cada individuo controlar el manejo y circulación que sobre su persona ha sido confiada a un tercero". ${ }^{27}$

De igual forma, el profesor Rojas Gómez reconoce tres áreas por las cuales el derecho a la intimidad termina siendo susceptible de protección: "[1] ocultabilidad material en el respectivo contexto, [2] voluntad de preservación respecto del conocimiento ajeno, e [3] idoneidad de las precauciones para asegurar el ocultamiento". ${ }^{28}$ La primera consiste en elementos propios de la persona cuyo ocultamiento dificultaría su identificación, como su rostro o su nombre, pero hay aspectos que sí son protegidos por esta calificación como es el caso de su sexualidad, creencias religiosas o pensamientos, acorde con los arts. 18 y 19 de la Constitución, por tanto aquí es importante la relación del sujeto con el contexto en general; en el caso de la correspondencia postal, por ejemplo, resulta imposible ocultar información como los datos del remitente y de destinatario, pero la información del conte-

26 Ibíd., p. 40, citando a: “Resolución 428 de la Asamblea Consultiva del Consejo de Europa (sic)”.

27 Ibíd., p. 40, citando a: Ferreira Rubio, Delia Matilde. El derecho a la intimidad. Editorial Universidad, Buenos Aires, 1982.

28 Rojas Gómez, Miguel Enrique. Op. cit., p. 37. 
nido de la carta sí es protegida. ${ }^{29}$ La segunda consiste en la voluntad de mantener reservado un conocimiento ajeno; es la decisión de la persona de guardar un secreto o exhibirlo al público; 30 habría problema cuando lo exhibe teniendo cláusula de confidencialidad o en el caso de un interrogatorio en un proceso judicial: con relación a la protección de guardar un secreto, encontramos los límites al deber de declarar en el art. 33 de la Carta Política. La tercera área consiste en que "lo íntimo sólo puede ser protegido como tal en cuanto se realice o se conserve de manera idónea para asegurar el ocultamiento" 31 ; si bien el ejemplo que expone el autor es la evacuación de desechos corporales en lugares públicos, posteriormente trata la comunicación entre personas, protegida por el derecho en el ya señalado art. 15 .

Hay que tener en cuenta que Rojas Gómez diferencia la privacidad individual y la privacidad intersubjetiva. En concreto, la diferencia radica en que una expresión del derecho a la intimidad, como es el caso de exámenes de ADN (art. 245, CPP) es individual, y es diferente cuando se trata de una interceptación de comunicaciones (art. 235, CPP), que es interpersonal. ${ }^{32}$ Concentrándonos en nuestra materia, cuando una persona decide comunicarse con otra, en ejercicio de su libertad, la persona escoge qué, cómo, cuándo y a quién transmitir un mensaje. Una obstrucción a esto sería

\footnotetext{
29 Ibíd., pp. 27-28.

30 Ibíd., p. 38.

31 Ídem.

32 Ibíd., pp. 81-112.
} 
una restricción a la libertad de la persona. Ahora, cuando una persona realiza una de esas actividades de forma pública ya no le correspondería la protección del derecho a la intimidad. ${ }^{33}$ Por esa razón se estudia la idoneidad del medio en que se da el mensaje y la voluntad de la persona de mantenerlo en secreto; esta información es cobijada por el art. 15 constitucional por ser considerada una "comunicación privada" y tiene una relación directa con el control de la información, como señalan Escobar López y Marulanda Otálvaro.

Concentrándonos en el tercer grupo que señalan estos dos profesores, y en relación con la calificación que presenta el profesor Rojas Gómez, la comunicación privada debe ser idónea para poder mantener el control de la información, sin olvidar que corresponde a una intimidad intersubjetiva. Sin embargo, hay una relación entre vida privada e información oficial, y la forma en que se relacionan estas dos termina creando los supuestos básicos de la relación Persona-Estado ${ }^{34}$. Precisamente en este punto, el art. 15 inc. 3 constitucional reza: "Sólo pueden ser interceptadas o registradas mediante orden judicial, en los casos y con las formalidades que establezca la ley", teniendo en cuenta que el Estado también tiene el deber de proteger a las personas y sus bienes según su art. 2, siendo este el fundamento para una investigación penal y para desarrollar actividades para mantener la seguridad nacional. De tal manera podemos deducir que sí se pueden hacer intromisiones, siempre y

33 Ibíd., p. 72.

34 Corte Constitucional, Sentencia T-011 de 1992. 
cuando el punto se encuentre regulado en una ley y se obtenga una orden judicial. ${ }^{35}$

La Corte Constitucional ha venido haciendo una clasificación de tipos de información, donde se distinguen los siguientes tipos: información pública, que puede ser obtenida sin reserva o impedimento alguno; información semiprivada, la que solo se puede conseguir a partir de una orden de una autoridad administrativa; información privada, que solamente se obtiene por orden judicial; e información reservada, que no se puede obtener, ni siquiera con autoridad judicial, en la que "[c]abría mencionar aquí la información genética, y los llamados 'datos sensibles ${ }^{36}$ o relacionados con la ideología, la inclinación sexual, los hábitos de la persona, etc". ${ }^{37}$ De igual forma, la Corte diferencia entre información impersonal y personal, haciendo claridad que el art. 15 constitucional protege la información personal. ${ }^{38} \mathrm{Si}$ bien la clasificación puede ser etérea al momento de concretarla en un caso, sirve para resaltar la importancia de distinguir de qué tipo de información se está discutiendo, más aun cuando

35 Cfr., T-349 de 1993; y cidH. Caso Escher y otros v. Brasil. Sentencia del 6 de julio de 2009, párr. 116; CIDH, Caso Tristán Donoso v. Panamá. Sentencia de 27 de enero de 2009, párrs. 56, 58; Naciones Unidas, Comité de Derechos Humanos, Observación General n. ${ }^{\circ}$ 16-Article 17 (The right to respect of privacy, family, home and correspondence, and protection of honour and reputation) HRI/GEN/1/Rev.7 at 162 de 28 de septiembre de 1988, párr. 4.

Corte Constitucional, Sentencia T-011 de 1992.

36 Corte Constitucional, Sentencia T-729 de 2002, citando a: Sentencia T-307 de 1999.

37 Corte Constitucional, Sentencia T-729 de 2002.

38 Ídem. 
se pueden encontrar diferentes grados de intimidad, no solo el personal sino también el familiar, social, o el gremial ${ }^{39}$ (todas estas de carácter intersubjetivo); y además se debe estudiar el alcance de la comunicación "privada”, en cuanto que puede comprenderse entre lo semiprivado y reservado.

Retomando la relación Persona-Estado, la Corte Constitucional considera que "[e]l Estado debe conocer lo mínimo necesario para que la persona viva en el contexto social gozando del máximo espacio vital a que tiene derecho para lograr el desarrollo de la personalidad". ${ }^{40}$ Por tanto, la regla general es que hay una prevalencia del derecho a la intimidad sobre el acceso a la información. ${ }^{41}$

En los casos de la interceptación de comunicaciones, hay un efecto en todos estos aspectos del derecho a la intimidad. La jurisprudencia constitucional ha establecido que:

El secreto de las comunicaciones, garantizado por el precepto constitucional en cita, es considerado por la doctrina como un derecho individual resultado del status

39 Corte Constitucional, Sentencia T-787 de 2004.

40 Corte Constitucional, Sentencia T-011 de 1992, citando a: Schneider, Hans Peter. Democracia y Constitución. Centro de Estudios Constitucionales, Madrid, 1991, p. 21. Cfr., Corte Constitucional, Sentencia T-787 de 2004, dice: salvo las excepciones previstas en la Constitución y la ley, que obliguen a las personas a revelar cierta información a partir de su reconocimiento o valoración como de importancia o relevancia pública; el resto de los datos que correspondan al dominio personal de un sujeto no pueden ser divulgados, a menos que el mismo individuo decida revelar autónomamente su acceso al público.

41 Corte Constitucional, Sentencia T-414 de 1992. 
libertatis de la persona, que, como ya se dijo, garantiza a ésta un espacio inviolable de libertad y privacidad frente a su familia, a la sociedad y al Estado. La inviolabilidad de la correspondencia es apreciada en cuanto preserva el derecho de la persona al dominio de sus propios asuntos e intereses, aún los intranscendentes, libre de la injerencia de los demás miembros de la colectividad $y$, especialmente, de quienes ejercen el poder público. ${ }^{42}$

Como la regla general es la prevalencia del derecho a la intimidad sobre la información, para que haya una injerencia por parte del Estado se requiere que haya una orden judicial dentro de las formalidades y requisitos legales. La Corte Interamericana de Derechos Humanos (CIDH) entiende que "la protección a la vida privada se concreta en el derecho a que sujetos distintos de los interlocutores no conozcan ilícitamente el contenido de las conversaciones telefónicas o de otros aspectos, como los ya mencionados, propios del proceso de comunicación". ${ }^{43}$ Dicho de otra forma, la injerencia que cumpla con los requisitos legales y con la autorización legal será lícita.

Sin embargo, como ha venido explicando la Corte Suprema de Justicia, lo que se prohíbe es la interceptación ajena, de tal manera que una persona puede interceptar su propia línea telefónica, grabar la conversación, e incluso solicitar

42 Corte Constitucional, Sentencia T-349 de 1993.

43 CIDH, Caso Escher y otros v. Brasil. Sentencia del 6 de julio de 2009, párr. 114. 
a la autoridad judicial competente que lo haga, dado que es su propia voluntad la que decide hacerla. ${ }^{44}$ Por tanto, no se necesita de autorización judicial cuando la víctima permite a la policía judicial hacer la interceptación. ${ }^{45}$ Ahora, Rojas Gómez considera que la potestad de interceptar y grabar la conversación es de cualquiera de las personas que estén en dicha conversación. ${ }^{46}$

44 Corte Suprema de Justicia-Sala de Casación Penal, Rad. 9579, Sentencia de 22 de octubre de 1996, citando Corte Suprema de Justicia-Sala de Casación Penal, Sentencia de 16 de marzo de 1988, M.P. Martínez Zúñiga. Este dice:

Por ello conviene advertir que cuando no se trate de grabar la propia voz, o recoger documentalmente la propia imagen, ni de interceptar la línea telefónica que se tiene, sino de registrar comunicaciones o imágenes privadas de otras personas, es necesario que se obre en cumplimiento de una orden emanada de autoridad judicial competente, en cuanto ello implica invadir la órbita de intimidad personal ajena, también protegida como derecho constitucional fundamental (art. 15), como se dejó dicho.

Cfr., Corte Suprema de Justicia-Sala de Casación Penal, Rad.13.948, Sentencia de 30 de noviembre de 200; Rad. 21.216 de 6 de agosto de 2003; Rad. 10.656 del 24 de noviembre de 2004; y Rad. 24.679 del 27 de julio de 2006.

45 Cfr., Corte Suprema de Justicia-Sala de Casación Penal, Rad. 13.148, Sentencia de 21 de noviembre de 2002; y Corte Suprema de Justicia-Sala de Casación Penal, Rad. 24.679, Sentencia de 27 de julio de 2006:

La Sala precisa en este caso que salvo cuando se requiera autorización judicial, la grabación, interceptación de la voz o la filmación de imágenes, será viable jurídicamente (con capacidad para servir como medio de prueba judicial) cuando exista o se exprese el consentimiento de todos quienes intervienen en la conversación o en el acto que es objeto de filmación o grabación, predicándose como excepción a lo afirmado aquel evento ya insistentemente desarrollado por la jurisprudencia - que hoy se reiterarelativo a la preconstitución de prueba cuando se es víctima de un delito y la obtención de la respectiva información comporta fines judiciales probatorios.

46 Rojas Gómez, Miguel Enrique. Op. cit., pp. 50, 51, 89. 


\subsubsection{Excepción: el derecho a la intimidad cede ante el derecho a la información por autorización judicial} La Convención Americana de Derechos Humanos (CADH) y el Pacto Internacional de Derechos Civiles y Políticos (PIDCP) tienen dos puntos en común: primero, que las injerencias no deben ser arbitrarias, y segundo, la ley necesariamente tiene el deber de proteger la intimidad. La autorización judicial revisa de manera precisa el cumplimiento del ordenamiento interno; la autorización debe ser razonada y ponderada de acuerdo con la situación concreta, con la carga de preferir la protección al derecho a la intimidad. ${ }^{47}$ Ante esto la Corte Constitucional ha expuesto tres requisitos para que se dé dicha autorización: "1. Que medie orden judicial; 2. Que se presente alguno de los casos establecidos en la ley; 3. Que se cumplan las formalidades señaladas en la ley". 48 Aunque en este caso la Corte habla expresamente de correspondencia, la regla se extiende a todas las formas de

47 Cfr., Cidh. Caso Escher y otros v. Brasil. Sentencia del 6 de julio de 2009, párr. 116; Caso Tristán Donoso v. Panamá, Sentencia de 27 de enero de 2009, párrs. 56, 58; Naciones Unidas, Comité de Derechos Humanos, Observación Generaln. ${ }^{\circ}$ 16-Article 17 (The right to respect of privacy, family, home and correspondence, and protection of honour and reputation), HRI/GEN/1/ Rev.7 at 162 de 28 de septiembre de 1988, párr. 4.

48 Corte Constitucional, Sentencia T-349 de 1993; Cfr., Corte Constitucional, Sentencia C-657 de 1996, Sentencia T-696 de 1996; y Cfr., cidH. Caso Escher y otros v. Brasil. Sentencia del 6 de Julio de 2009, párrs. 129, 168. Esta última dice: "Como ya se indicó, para que resulte conforme a la Convención Americana una injerencia debe cumplir con los siguientes requisitos: a) estar prevista en ley; b) perseguir un fin legítimo, y c) ser idónea, necesaria y proporcional. En consecuencia, la falta de alguno de dichos requisitos implica que la injerencia es contraria a la Convención". 
comunicación. ${ }^{49}$ Por el avance tecnológico, la interceptación de correspondencia escrita ha perdido impacto; sin embargo, se ha venido expandiendo a otros sistemas de comunicación, como son el teléfono celular e Internet. ${ }^{50}$

Es importante resaltar que técnicamente interceptar consiste en apoderarse de, interrumpir, $\mathrm{u}$ obstruir una comunicación; mientras que registrar es examinar con cuidado el contenido de dicha comunicación. ${ }^{51}$ Cualquiera de las dos acciones es violación al derecho a la intimidad, independientemente del medio o método con que se haya hecho. ${ }^{52}$ Es muy común encontrar que, tanto legal como jurisprudencialmente, se entienda por interceptar los dos conceptos expuestos. Esto se debe a que originalmente se estaba enfocado en la correspondencia, por tanto era posible hacer la distinción; sin embargo, por ese desarrollo tecnológico, estos dos se han terminado mezclando en un mismo momento. Adicionalmente encontramos la acción de grabar, dado que muchas veces no basta con escuchar la conversación, sino también se hace la grabación de la misma. Ante esto la Corte ha dicho:

En esa medida, las grabaciones de imagen o de voz realizadas en ámbitos privados de la persona, con destino a

49 Cfr., Corte Constitucional, Sentencia C-131 de 2009.

50 Cfr., Fierro Méndez, Heliodoro. Prueba ilícita. Interceptación de comunicaciones y registro de computadores. Ediciones Doctrina y Ley, Bogotá, 2012, títulos primero y segundo.

51 Cfr., Corte Constitucional, Sentencia T-696 de 1996.

52 Cfr., Ídem. 
ser publicadas o sin ese propósito, constituyen violación del derecho a la intimidad personal, si las mismas no han sido autorizadas directamente por el titular del derecho y, además, en caso extremo, si no han sido autorizadas expresa y previamente por autoridad judicial competente. El resultado de la recolección de la imagen o la voz sin la debida autorización del titular implica, sin más, el quebrantamiento de su órbita de privacidad y, por tanto, la vulneración del derecho a la intimidad del sujeto. ${ }^{53}$

Siendo así, hay que tener en cuenta que el proceso de una interceptación como se la entiende generalmente comprende a tres acciones: primero, interceptar propiamente dicho; ${ }^{54}$ segundo, grabar en ámbitos de la comunicación; y tercero, ya grabada, registrar la información. Hay que tener en cuenta que la interceptación de comunicaciones solo le es permitida a las entidades públicas, principalmente a la Policía Judicial, y solamente con orden judicial como establece la Constitución, por lo que le está prohibido a las entidades privadas y a las entidades públicas que no tengan esta competencia. La jurisprudencia ha establecido que:

La Corte Constitucional, en guarda de la cabal interpretación y aplicación de las normas constitucionales enunciadas y de los tratados internacionales sobre de-

53 Corte Constitucional, Sentencia T-233 de 2007.

${ }_{54}$ Una descripción del procedimiento de interceptaciones en concreto, la encontramos en Fierro Méndez Heliodoro. Op. cit., título segundo. 
rechos humanos, que han sido estrictos y celosos en la materia (Cfr. Convención Americana sobre Derechos Humanos, "Pacto de San José de Costa Rica”, aprobada mediante Ley 16 de 1992, artículo 11; Pacto Internacional de Derechos Civiles y Políticos, aprobado por Ley 78 de 1968, artículo 17), debe declarar sin ambages que ninguna persona pública ni privada, por plausible o encomiable que sea el objetivo perseguido, está autorizada para interceptar, escuchar, grabar, difundir ni transcribir las comunicaciones privadas, esto es, las que tienen lugar entre las personas mediante conversación directa, o por la transmisión o registro de mensajes, merced a la utilización de medios técnicos o electrónicos aptos para ello, tales como teléfonos convencionales o celulares, radioteléfonos, citófonos, buscapersonas, equipos de radiocomunicaciones, entre otros, A MENOS QUE EXISTA PREVIA Y ESPECIFICA ORDEN JUDICIAL Y QUE ELLA SE HAYA IMPARTIDO EN EL CURSO DE PROCESOS, EN LOS CASOS Y CON LAS FORMALIDADES QUE ESTABLEZCA LA LEY, según los perentorios términos del artículo 15 de la Constitución Política ${ }^{55}$ (mayúsculas hacen parte del texto original; cursivas fuera del texto).

Por lo anterior, encontramos que la regla general es que no se pueda hacer interceptación de comunicaciones privadas, a menos que haya una orden judicial que lo permita,

55 Corte Constitucional, Sentencia C-626 de 1996; Cfr., Corte Constitucional, sentencias C-382 de 1996, T-233 de 2007 y C-131 de 2009. 
teniendo en cuanta que aun así hay una carga a favor del derecho a la intimidad en cuanto es una manifestación de la dignidad humana. Dicha interceptación solo podrán hacerla aquellas autoridades públicas que tengan esa función, y debe estar sujeta a lo reglamentado por la ley, dentro de un debido proceso y bajo la protección del bien jurídico tutelado penalmente. Por tanto, entramos a estudiar y precisar el debido proceso penal en general, y la interceptación en particular.

\subsection{Derecho al debido proceso y su relación con el derecho a la intimidad}

Entendemos el debido proceso como "el conjunto de garantías previstas en el ordenamiento jurídico, a través de las cuales se busca la protección del individuo incurso en una actuación judicial o administrativa, para que durante su trámite se respeten sus derechos y se logre la aplicación correcta de la justicia” ${ }^{56}$ Por tal razón el proceso penal, con el intento de ser metódico y lógico, construye una relación entre Ius Puniendi del Estado por un lado, y por el otro el derecho de la defensa de la persona, en el que se busca garantizar sus derechos. ${ }^{57}$

Así las cosas, describiremos someramente el proceso penal de modo general para tener claro el marco de legalidad en el que se debe producir la debida autorización para esas intervenciones, y luego se explicará la forma en que se

\footnotetext{
56 Corte Constitucional, Sentencia C-980 de 2010.

57 Cfr., Corte Constitucional, Sentencia C-782 de 2005.
} 
introduce la interceptación de comunicaciones, con algunos comentarios relacionados a este tema sobre las actividades de inteligencia. Seguidamente entramos a estudiar la regla de exclusión, siendo esta una garantía de protección en casos de violación al derecho a la intimidad, y terminamos revisando dentro de ese marco de legalidad los tres casos escogidos de referencia en cuanto a la interceptación de comunicaciones.

\subsubsection{Breve descripción de los procesos penales en Colombia}

\subsubsection{Sistemas procesales antecesores a la Ley 906 de 2004}

Antes del Acto Legislativo 03 de 2002 y de la Ley 906 de 2004 se manejaba un sistema judicial con indudables rasgos inquisitivos, donde la Fiscalía era una autoridad judicial. En el último de esos códigos de procedimiento penal, en el contexto del Decreto 2700 de 1991, había un control sobre las interceptaciones de comunicaciones, según el art. 351, en el que si la solicitud para realizar la interceptación provenía del fiscal delegado, se requería autorización por parte de la Dirección Nacional de Fiscalías, en consonancia con el art. 35.5 del Decreto 2699 de 1991, anterior Estatuto Orgánico de la Fiscalía. Esta situación procedía en la etapa de instrucción. Pero si la iniciativa surgía de la Policía Judicial, se regía por el art. 47 del Decreto 2699, se requería la autorización del fiscal encargado, lo que se daba en la investigación previa. ${ }^{58}$ Esta

58 Cfr., Corte Suprema de Justicia-Sala de Casación Penal, Rad. 9.579, 
forma de control buscaba que "al menos dos funcionarios intervengan en la decisión a efectos de garantizar la debida utilización de tan extrema medida" ${ }^{59}$ Después del Decreto 2700 de 1991, se expidió la Ley 600 de 2000, que pretendió introducir algunos rasgos de adversarialidad, aunque mínimos; regula este instituto en el art. 301, en consonancia con el Decreto 2699 de 1991, sin que se produzcan mayores cambios. Estos sistemas con alguna tendencia inquisitiva, aun siendo mixtos, se caracterizaban, entre otras cosas, por el hecho de que la Fiscalía tenía amplísimas facultades judiciales, como la de determinar por sí y ante sí la detención preventiva de los sindicados, o la de declarar la preclusión de las investigaciones.

El sistema penal acusatorio se cristaliza con el Acto Legislativo 03 de 2002, en el que se introducen cambios constitucionales para permitir el paso al sistema penal oral y adversarial o acusatorio, que termina formalizándose en la Ley 906 de 2004. Entre las modificaciones, el art. 250, num. 2 de la Constitución quedó de la siguiente manera:
Art 250. En ejercicio de sus funciones la Fiscalía General de la Nación, deberá:
$[\ldots]$

Sentencia de 22 de octubre de 1996 y Corte Suprema de Justicia-Sala de Casación Penal, Rad. 13.255, Sentencia de 23 de noviembre de 2000.

59 Corte Suprema de Justicia-Sala de Casación Penal, Rad. 9.579, Sentencia de 22 de octubre de 1996. 
Adelantar registros, allanamientos, incautaciones e interceptaciones de comunicaciones. En estos eventos el juez que ejerza las funciones de control de garantías efectuará el control posterior respectivo, a más tardar dentro de las treinta y seis (36) horas siguientes. ${ }^{60}$

Originalmente, el Acto Legislativo adicionaba "al solo efecto de determinar su validez". Sin embargo, esta parte final fue declarada inconstitucional, porque el juez no solo debe revisar su legalidad formal, sino también su legalidad material. ${ }^{61}$

Si bien es cierto que ahora la Fiscalía en su mayoría de funciones actúa como parte del proceso, en algunas actuaciones sigue revestida de autoridad judicial. La Corte Constitucional entiende que la Fiscalía tiene ciertas prevalencias para restringir el derecho de la intimidad, en esas tres actuaciones (registro y allanamientos, incautaciones e interceptaciones de comunicaciones) y luego de que se adelanten estas actividades, sí tendría un control posterior por parte de juez de garantías. ${ }^{62}$ Las demás actuaciones que impliquen una vulneración de derechos fundamentales requieren control

60 República de Colombia, Constitución Política de Colombia, modificada por: Congreso de la República. Acto Legislativo 03 de 2002. "Por medio del cual se modifican los artículos 15, 24, 28 y 250 de la Constitución Política de Colombia para enfrentar el terrorismo", publicado en el Diario Oficial n. ${ }^{\circ}$ 45.406, de 19 de diciembre de 2003.

61 Corte Constitucional, Sentencia C-092 de 2003.

62 Ídem. 
previo, en concordancia con el 246 del CPP vigente y del art. 250, num. 3 de la Constitución.

Se introduce en la Ley 906 una división de tareas entre el fiscal, el juez de control de garantías y el juez de conocimiento: el fiscal se encarga de acusar y allegar el material probatorio, el juez de control de garantías se revisa la legalidad del material probatorio, y el juez de conocimiento se ocupa de su valoración. ${ }^{63}$ Ahora bien, el art. 246 establece que se requiere el control previo de aquellas actuaciones que afecten derechos y garantías fundamentales que no se hayan nombrado en el capítulo "actuaciones que no requieren autorización judicial previa” (arts. 213 a 245). ${ }^{64}$

Si bien uno de los cambios más importante gracias al Acto Legislativo 03 de 2002 es la introducción del juez de control de garantías, es cierto que el fiscal en el proceso de Ley 906 está revestido de cierta autoridad judicial para ordenar a la Policía Judicial que realice la interceptación de comunicaciones, a diferencia del Decreto 2700 de 1991 y la Ley 600 de 2000, donde se requería una autorización judicial previa, que le correspondía diligenciar ante a la misma entidad. En el anterior estatuto orgánico de la Fiscalía, Decreto 2699 de 1991, sí se tenía que hacer un control previo dependiendo de en qué momento tenía lugar, ya fuera por el fiscal, cuando

63 Ídem.

64 A pesar ello, dicho capítulo tiene un espectro mucho más amplio que las tres actuaciones que dice el art. 250 constitucional que requieran control posterior, salvo la búsqueda selectiva en bases de datos, por la Sentencia C-36 de 2007, y los exámenes que involucren al indiciado o al imputado, por la Sentencia C-334 de 2010, que requieren control previo. 
era por iniciativa por la Policía Judicial, o por la Dirección Nacional de Fiscalías, cuando era por iniciativa del fiscal delegado. En el actual Estatuto Orgánico, Ley 938 de 2004, se omitió dicho control previo interno.

\subsubsection{Descripción general del proceso penal vigente}

$\mathrm{Al}$ suceder un hecho jurídicamente relevante, se tiene la noticia criminis; después de que la Policía Judicial haya realizado los actos urgentes, esta le presenta un informe a la Fiscalía, la que asume conocimiento, según el art. 66 del cPr. Se adopta un programa metodológico de investigación, tal como lo señala el art. 207. En dicho programa se ordenan tres posibles clases de actividades: unas que no requieren autorización judicial, previstas en los artículos 213 y siguientes; otras que requieren control de legalidad posterior según el art. 237; y las que requieren control previo según los artículos 246 y siguientes. A partir de estas tres opciones se van conformando los elementos materiales probatorios y la evidencia testimonial potencial, y cuando el fiscal considera que tiene suficiente material probatorio que conlleve una inferencia razonable sobre los hechos que se estén investigando, solicita que se adelante la audiencia de imputación según los artículos 286 y siguientes, ante el juez de control de garantías, según el art. 154 num. 6, la que tiene por fin comunicarle a la persona que es imputada, e interrumpir la prescripción de la acción penal. ${ }^{65}$

65 Cfr., Ramírez Contreras, Luis Fernando. Las audiencias en el sistema penal acusatorio. 2. ${ }^{a}$ ed. Editorial Leyer, Bogotá, 2007, pp. 25-28. 
Ante el juez de control de garantías se adelantarán las audiencias de control previo o posterior de las evidencias físicas y elementos materiales probatorios obtenidos durante la indagación e investigación. El control de legalidad, tanto previo como posterior, tiene como "propósito específico el de llevar a cabo la revisión formal y sustancial del procedimiento utilizado en la práctica de las citadas diligencias, esto es, verificar que se hayan respetado los parámetros constitucionales y legales establecidos para su autorización y realización, e igualmente, que la medida de intervención no haya desconocido garantías fundamentales (CP art. 250 y CPP art. 39)" ${ }^{66}$ De igual forma, el juez de control de garantías tendrá competencia residual sobre aquello que no le fue asignado a otro juez, por lo que también se adelantan ante este otras actuaciones. ${ }^{67}$

Ya hecha la imputación y las audiencias preliminares que haya sido necesario practicar, el art. 175 ordena que el fiscal presente el escrito de acusación, y con él se fijará la fecha de audiencia de acusación. En ella, se acusará por los hechos jurídicamente relevantes, con una calificación del delito o delitos, y se hará un descubrimiento del material probatorio por parte del fiscal, acorde a los arts. 336 y siguientes. ${ }^{68}$

66 Corte Constitucional, Sentencia C-025 de 2009.

67 Ibíd., pp. 28-32. Otras actuaciones como las que señalan los artículos 84 (medidas cautelares sobre bienes susceptibles de comiso), 134 (medidas de protección de víctimas), 284 (pruebas anticipadas), 297 (solicitud de orden de captura), 306 (medida de aseguramiento), 317 (petición de libertad), 318 (solicitud de Revocatoria) y 327 (principio de oportunidad).

68 Ibíd., pp. 33-36. 
Hay que tener presente que el juzgamiento formalmente se inicia a partir de esta audiencia; antes de esta están las etapas de indagación e investigación en las que se desarrollan diligencias preliminares. ${ }^{69}$

Realizada la audiencia de acusación, se efectuará la audiencia preparatoria según los arts. 175 y 343. En esta audiencia, regulada principalmente por el art. 355 y siguientes, se harán observaciones sobre los elementos materiales probatorios descubiertos por la Fiscalía; habrá descubrimiento de los elementos probatorios de la defensa, se acordarán las estipulaciones que deseen las partes; se solicitarán los medios probatorios propuestos para practicar en el juicio oral. En este momento procesal se podrá solicitar la exclusión, rechazo o inadmisibilidad de las pruebas ilícitas, ilegales o impertinentes, y se decretarán las pruebas que hayan pasado el análisis de conducencia, pertinencia y utilidad por parte del juez, decisión contra la que se pueden interponer recursos de reposición y apelación. Es entonces esta la oportunidad final de enunciar, solicitar, decretar e impugnar sobre la introducción de resultados de interceptación de comunicaciones al juicio oral.

Al concluir la audiencia preparatoria se fija fecha y hora para desarrollar el juicio oral, según los arts. 175, 366 y siguientes; al finalizar este se anunciará el sentido del fallo y

69 Cfr. Montealegre Lynett, Eduardo y Bernal Cuéllar, Jaime El proceso penal. Estructura y garantías procesales. Tomo II. Universidad Externado de Colombia, 6. ${ }^{\text {a }}$ ed. Bogotá, 2013, p. 761. 
se dictará la sentencia de acuerdo con los arts. 446 y $447 . .^{70}$ Cuando el fallo quede en firme se hará una solicitud de incidente de reparación integral de perjuicios.

Ante estas providencias se puede interponer recurso de apelación, según lo previsto por los arts. 20 y 176 al 179A, donde resaltamos las causales del art. 177; resaltamos el inc. 1. num. 5 que lo prevé para la decisión de exclusión de la prueba, y el inc. 2 num. 4 que trata del control de legalidad del diligenciamiento de allanamiento y registro, retención de correspondencia, interceptación de comunicaciones o recuperación de información dejada al navegar por Internet.

Asimismo, encontramos que ante la sentencia de segunda instancia se puede interponer recurso de casación, donde cabría la causal de no haberse decretado la exclusión de la prueba, según el art. 180 y siguientes del Código, alegando error de derecho por falso juicio de legalidad. ${ }^{71}$ En algunos casos excepcionales se podría interponer acción de tutela contra providencia judicial por incurrir en "vías de hecho", es decir "aquellas actuaciones judiciales en las que el juez que decide un conflicto jurídico asume una conducta que contraría de manera evidente el ordenamiento jurídico vigente

70 Ramírez Contreras, Luis Fernando. Op. cit., pp. 38-40. Teniendo en cuenta las modificaciones de Ley.

71 Cfr., Corte Suprema de Justicia-Sala de Casación Penal, Rad. 29853, Sentencia de 20 de agosto de 2008. Esta dice: "el yerro se cristaliza cuando el fallador valora o aprecia un medio de prueba que desconoce alguna de esas ritualidades, o porque califica de ilegal [o ilícita] una que sí las satisface y por tanto es válida”. 
violando derechos fundamentales", ${ }^{72}$ y se podría presentar esta acción alegando un defecto fáctico ${ }^{73}$, positivo ${ }^{74}$.

Hay que tener en cuenta que para que proceda la acción de tutela, aparte de los requisitos propios de esta, se requiere que la prueba por la cual se interpuso sea la única razón para de declarar la culpabilidad del procesado. ${ }^{75} \mathrm{El} \mathrm{juez} \mathrm{de}$ tutela no puede suplantar al juez de instancia; por lo tanto, solamente podrá estudiar si hubo una evidente irregularidad, y en lo que nos interesa, en la no aplicación de la regla de exclusión. ${ }^{76}$ Por tal razón, aunque la aplicación de la regla de exclusión es sobre pruebas, si la sentencia tiene como pilar fundamental dentro de la ratio decidendi una prueba ilícita o ilegal, al declarar su exclusión, se puede derrumbar toda la ratio, y necesariamente se tendrá que declarar el amparo, y con ello la nulidad del proceso desde la práctica de pruebas por desembocar en violación del principio de congruencia probatoria. $^{77}$

72 Corte Constitucional, Sentencia SU-159 de 2002.

73 Ídem. Esto es, "la aplicación del derecho sin contar con el apoyo de los hechos determinantes del supuesto legal a partir de pruebas válidas".

74 Ídem. Encontramos que hay dos dimensiones: uno negativo, que corresponde a cuando el juez no valora la prueba sin una razón valedera; y otro positivo, que es el punto de nuestro interés, el cual "se presenta generalmente cuando aprecia pruebas que no ha debido admitir ni valorar, porque, por ejemplo, fueron indebidamente recaudadas (art. $29 \mathrm{cN}$ )". Es decir, el defecto fáctico en su dimensión positiva consiste en la no aplicación de la regla de exclusión.

75 Ídem.

76 Corte Constitucional, Sentencia T-233 de 2007.

77 Cfr., Corte Constitucional, sentencias T-916 de 08 y T-233 de 2007, entre otras; y Corte Suprema de Justicia-Sala de Casación Penal, Rad. 24.679, Sentencia de 27 de julio de 2006: en esta no declara la nulidad del proceso por- 


\subsubsection{Descripción del proceso para desarrollar la interceptación de comunicaciones}

En el momento procesal donde la Fiscalía abre indagación preliminar tras la noticia de un delito, y junto con la Policía Judicial establece el programa metodológico en el que establece la forma como se va a adelantar la investigación, según se había señalado, la Fiscalía cuenta con tres vías para obtener material probatorio, entre las que encontramos las acciones que requieren control posterior por el juez de control de garantías. ${ }^{78}$ Una de las actividades que requieren control posterior es la interceptación de comunicaciones, para la que se necesitará primero una orden del fiscal a cargo de la investigación; en ese caso, el fiscal actúa en función de autoridad judicial..$^{79}$ Dicha orden debe ser escrita, de acuerdo con el art. 235 del CPP, y debe fundamentarse en cuatro condiciones específicas:

\section{Debe hacer referencia a una conducta delictiva por el cual se concentra la interceptación;}

que había aún suficiente material probatorio para que el fallo quedara firme. En concreto, dice:

En efecto aun cuando se suprimiera el video como medio probatorio por su eventual ilicitud, la situación jurídica que se define en este fallo no sufriría modificación sustancial pues la reunión en la casa 39 de la Urbanización Colina Campestre de Yopal y la recepción en ella del dinero, son hechos demostrados plenamente con abundante prueba testimonial y aceptados por el mismo acusado. De tal modo que su eliminación en el proceso carece de la importancia que le atribuye la defensa.

78 Ramírez Contreras, Luis Fernando. Op. cit., p. 121.

79 Cfr., Corte Constitucional, Sentencia C-540 de 2011; y Montealegre Lynett, Eduardo y Bernal Cuéllar, Jaime. Tomo II. Op. cit., p. 281. 
2. Definir la persona por el cual recae la interceptación;

3. Especificar los números telefónicos; y

4. Definir el tiempo en que se desarrolla la interceptación. ${ }^{80}$

Con relación al último punto, una interceptación tendrá como plazo máximo seis meses, ${ }^{81}$ pero si la Fiscalía considera que es necesario prorrogarla, es exigido un control de legalidad previo; según la Sentencia C-131 de 2009, tras la modificación de la Ley 1142 de 2007, la prórroga sí requiere control previo. Después, regla que se dio por jurisprudencia constitucional, quedó incorporada directamente en el CPP gracias a la Ley 1453 de 2011.

Si bien el control posterior no tiene un capítulo específico destinado, lo encontramos en el art. 237. En su primer inciso dice:

Dentro de las veinticuatro (24) horas siguientes al recibimiento del informe de Policía Judicial sobre las diligencias de las órdenes de registro y allanamiento, retención de correspondencia, interceptación de comunicaciones o recuperación de información producto de la transmisión de datos a través de las redes de comunicaciones, el fiscal

80 Farfán Molina, Francisco. La interceptación de Comunicaciones telefónicas en el proceso penal y disciplinario. Ediciones Nueva Jurídica, Bogotá, 2008, pp. 39-43.

81 A pesar que el art. 235 dice que se tiene seis meses, el manual de procedimiento de la Fiscalía permite hasta tres meses. Cfr., Fiscalía General de la Nación. Manual de procedimientos de la Fiscalía en el sistema penal acusatorio. Fiscalía General de la Nación, Bogotá, 2009, p. 50. 
comparecerá ante el Juez de Control de Garantías, para que realice la audiencia de revisión de legalidad sobre lo actuado. ${ }^{82}$

Siendo así, encontramos que para hacer valer la interceptación de comunicaciones, se requiere control posterior por parte del juez de control de garantías para validar el acto de investigación, pero para que este posteriormente sea introducido al proceso penal tendrá que presentarse en la audiencia de acusación y se decidirá sobre su admisión o rechazo en la audiencia preparatoria. Teniendo en cuenta el momento procesal, el derecho del indiciado de estar presente en la audiencia de control posterior puede variar: cuando la interceptación se realiza después de la audiencia de imputación, el parágrafo del art. 237 ordena que se cite al imputado y a su defensor a la audiencia de control posterior. Pero si se realiza la interceptación antes de que se haga imputación, la Sentencia C-025 de 2009 (donde declara inexequible la palabra "solo", y declara exequible el inciso segundo del art. 237) considera lo siguiente:

[C] uando el indiciado tenga noticia de que en las diligencias practicadas en la etapa de indagación anterior a la formulación de la imputación, se está investigando su participación en la comisión de un hecho punible, el juez de control de garantías debe autorizarle su participación

82 Corte Constitucional, Sentencia C-025 de 2009. 
y la de su abogado en la audiencia posterior de control de legalidad de tales diligencias, si así lo solicita. ${ }^{83}$

Es decir, si se ordena una interceptación con anterioridad a la imputación, no se tiene el deber de citar al control posterior de legalidad al indiciado que no tiene conocimiento de la existencia de la indagación. Pero cuando un indiciado sabe que se adelanta una indagación en su contra, el juez debe autorizar su participación en las de control posterior. Si se ordena o se realiza la interceptación con posteridad a la imputación, el juez debe citar a la contraparte (Fiscalía y víctima o imputado) y su abogado a la audiencia de control posterior.

La decisión del juez de control de garantías sobre el control de legalidad y de constitucionalidad del material probatorio, en este caso de la interceptación de comunicaciones, debe estar sujeta a un juicio de proporcionalidad. Es decir, para tomar la decisión el juez debe revisar tanto la idoneidad, necesidad y proporcionalidad en estricto sentido ${ }^{84}$, y ante

83 Corte Constitucional, Sentencia C-025 de 2009; esta sentencia de constitucionalidad le da igual alcance para los arts. 242 (actuación de agentes encubiertos), 243 (entrega vigilada), 244 (búsqueda selectiva en bases de datos), y 245 (exámenes de ADN que involucren al indiciado o al imputado).

84 Montealegre Lynett, Eduardo y Bernal Cuéllar, Jaime. Tomo II. Op. cit., pp. 288, 289; Cfr., Novoa Velásquez, Néstor Armando. Nulidades en el procedimiento penal. Actos procesales y acto prueba. Sistemas mixto inquisitivo y mixto acusatorio. Tomo I. Editorial Biblioteca Jurídica Diké, Bogotá, 2011, pp. 679-681; y Alexy, Robert. "Tres escritos sobre los derechos fundamentales y la teoría de los principios". Universidad Externado de Colombia, Bogotá, 2003; Cfr., CIDH. Caso Escher y otros v. Brasil. Sentencia del 6 de julio de 2009, párr. 129. 
ello revisar los principios propios del derecho vulnerado. ${ }^{85}$ En el caso de que la defensa participante se encuentre insatisfecha con la decisión del juez de control de garantías por el control de legalidad que se hizo sobre la interceptación, ya sea por violación de los requisitos formales o sustanciales, puede interponer recurso de apelación, o alegar la exclusión de esta en la audiencia preparatoria directamente ante el juez de conocimiento.

85 Corte Constitucional, Sentencia T-787 de 2004. Al momento de hacer el control de proporcionalidad en sentido estricto resulta necesario tener en cuenta los cinco principios que enumeró la Corte Constitucional para delimitar "lo público" de lo "privado":

El principio de libertad, según el cual, los datos personales de un individuo, sólo pueden ser registrados o divulgados con el consentimiento libre, previo, expreso o tácito del titular, a menos que el ordenamiento jurídico le imponga la obligación de relevar dicha información, en aras de cumplir un objetivo constitucionalmente legítimo. En este contexto, la obtención y divulgación de datos personales, sin la previa autorización del titular o en ausencia de un claro y preciso mandato legal, se consideran ilícitas. [2] El principio de finalidad, el cual se expresa en la exigencia de someter la recopilación y divulgación de datos, a la realización de una finalidad constitucionalmente legítima, lo que impide obligar a los ciudadanos a relevar datos íntimos su vida personal, sin un soporte en el Texto Constitucional que, por ejemplo, legitime la cesión de parte de su interioridad en beneficio de la comunidad. [...] De conformidad con [3] el principio de necesidad, la información personal que deba ser objeto de divulgación, se limita estrechamente a aquella que guarda relación de conexidad con la finalidad pretendida mediante su revelación. Así, queda prohibido el registro y la divulgación de datos que excedan el fin constitucionalmente legítimo. Adicionalmente, [4] el principio de veracidad, exige que los datos personales que se puedan divulgar correspondan a situaciones reales y, por lo mismo, se encuentra prohibida la divulgación de datos falsos o erróneos. Por último, [5] el principio de integridad, según el cual, la información que sea objeto de divulgación debe suministrarse de manera completa, impidiendo que se registre y divulgue datos parciales, incompletos o fraccionados. 
Posteriormente, el proceso penal tiene varias oportunidades y mecanismos para revisar el material probatorio: es revisado por el juez de conocimiento en el transcurso del proceso en primera instancia, en audiencia preparatoria y en juicio oral; por el superior jerárquico en caso de que se interpongan recursos de apelación, ya sea contra la decisión de admitir la prueba en la audiencia preparatoria, durante el juicio en primera y en segunda instancia si hay debate de exclusión probatoria, o en contra de la sentencia de primera instancia; también podrá ser revisado por la Corte Suprema de Justicia en recurso de casación; y eventualmente, en casos de acción de tutela contra sentencias, por jueces en primera y sengunda instancia y la Corte Constitucional en casos de acción de tutela contra sentencias.

\subsubsection{Comentarios sobre las actividades de inteligencia y contrainteligencia}

Se debe partir de que las actividades de inteligencia y contrainteligencia tienen una relación directa con la investigación criminal y con la protección de amenazas contra la seguridad nacional. Estas actividades generan una tensión entre el derecho a la intimidad, el principio de legalidad y el debido proceso, con la defensa y la seguridad nacional. Dentro de las diferentes actividades de inteligencia que se desarrollan, se encuentra el monitoreo del espectro electromagnético y la interceptación de comunicaciones.

Encontramos que se han venido adelantando diferentes intentos a través de los cuales se busca fortalecer el marco jurídico de las actividades de inteligencia. Entre ellos está 
la Ley 1288 de 2009, que fue declarada inexequible por la Sentencia C-913 de 2010, porque afectaba derechos fundamentales y ello hace que sea necesaria una Ley estatutaria. Se volvió a adelantar el proceso legislativo y se expidió la Ley 1621 de 2013, y seguidamente la Corte Constitucional revisó su constitucionalidad por medio de la Sentencia C-540 de 2012. Antes de esta Ley, la actividad de inteligencia se encontraba dispersa en diferentes normas, haciendo complejo su estudio. La Corte Constitucional, en la última sentencia citada, hace referencia a la Ley 57 de 1985 que regula el acceso a la información, como también a las Leyes 594 de 2000 y 850 de 2003, entre otras.

Enfocándonos en la Ley 1621 de 2013, encontramos que en el art. 2 define la función de inteligencia de la siguiente manera:

Artículo $2^{\circ}$. Definición de la función de inteligencia y contrainteligencia. La función de inteligencia y contrainteligencia es aquella que desarrollan los organismos especializados del Estado del orden nacional, utilizando medios humanos o técnicos para la recolección, procesamiento, análisis y difusión de información, con el objetivo de proteger los derechos humanos, prevenir y combatir amenazas internas o externas contra la vigencia del régimen democrático, el régimen constitucional y legal, la seguridad y la defensa nacional, y cumplir los demás fines enunciados en esta ley. 
La Sentencia C-540 de 2012, siguiendo a la Sentencia T-708 de 2008, "defin[e] la inteligencia como la recopilación y análisis de información relativa al sostenimiento de la seguridad general que debe estar circunscrita al respeto de los derechos fundamentales y al sistema de control de poderes". ${ }^{86}$ También es importante resaltar que esta función de recopilación y análisis de la información tiene como límite, diciéndolo expresamente el art. 4, el derecho internacional humanitario, el derecho internacional de los derechos humanos, la Constitución y la ley, y establece que solamente se ejercerá para tres fines:

86 Corte Constitucional, Sentencia C-540 de 2012; Cfr., Corte Constitucional, sentencias T-708 de 2008 y C-1011 de 2008. También Cfr., C-913 de 2010, donde dice:

De los anteriores conceptos (haciendo referencia a otros sistemas y al marco nacional) pueden destacarse, entre otros, los siguientes elementos comunes acerca de las labores de inteligencia y contrainteligencia: i) se trata de actividades de acopio, recopilación, clasificación y circulación de información relevante para el logro de objetivos relacionados con la seguridad del Estado y de sus ciudadanos; ii) el propósito de esas actividades y el de la información a que se ha hecho referencia es prevenir, controlar y neutralizar situaciones que pongan en peligro tales intereses legítimos, así como hacer posible la toma de decisiones estratégicas que permitan la defensa y/o avance de los mismos; iii) es inherente a estas actividades el elemento de la reserva o secreto de la información recaudada y de las decisiones que en ella se sustentan, dado que la libre circulación y el público conocimiento de las mismas podría ocasionar el fracaso de esas operaciones y de los objetivos perseguidos; iv) dado que se trata de detectar y prevenir posibles hechos ilícitos y/o actuaciones criminales, la información de inteligencia y contrainteligencia es normalmente recaudada y circulada sin el conocimiento, ni menos aún el consentimiento de las personas concernidas. 
a. Asegurar la consecución de los fines esenciales del Estado, la vigencia del régimen democrático, la integridad territorial, la soberanía, la seguridad y la defensa de la Nación;

b. Proteger las instituciones democráticas de la República, así como los derechos de las personas residentes en Colombia y de los ciudadanos colombianos en todo tiempo y lugar - en particular los derechos a la vida y la integridad personal - frente a amenazas tales como el terrorismo el crimen organizado, el narcotráfico, el secuestro, el tráfico de armas, municiones, explosivos y otros materiales relacionados, el lavado de activos, $y$ otras amenazas similares; y

c. Proteger los recursos naturales y los intereses económicos de la Nación. ${ }^{87}$

Estas actividades de inteligencia y contrainteligencia tendrán que revisarse a la luz del test de proporcionalidad y sus subprincipios de idoneidad, necesidad y proporcionalidad, stricto sensu, dado que si bien son unas intromisiones a derechos fundamentales, el legislador consideró que estas van encaminadas al cumplimiento de unos fines legítimos, y por ello se reguló como una Ley Estatutaria. Es decir, las actuaciones de los organismos de inteligencia (se señalan las

87 Congreso de la República. Ley 1621 de 2013. "Por medio de la cual se expiden normas para fortalecer el Marco Jurídico que permite a los organismos que llevan a cabo actividades de inteligencia y contrainteligencia cumplir con su misión constitucional y legal, y se dictan otras disposiciones", publicada en el Diario Oficial n. ${ }^{\circ} 48.764$ de 17 de abril de 2013, art. 4. 
dependencias de Fuerzas Militares, Policía Nacional, Unidad de Información y Análisis Financiero (UIAF) y aquellos organismos que sean facultados por la ley), como parte de la revisión de las actividades en relación de estas con los fines, tendrán que someterse a un test de proporcionalidad. ${ }^{88}$

Concentrándonos en nuestra materia, el art. 17 trata el monitoreo del espectro electromagnético e interceptación de comunicaciones. Se distingue el monitoreo de la interceptación, en cuanto el primero consiste en un rastreo de manera aleatoria e indiscriminada en el que se puede presentar captación incidental de comunicaciones sin que implique un seguimiento individual. La interceptación consiste precisamente en un seguimiento individual y concreto propio de la investigación penal donde se buscan elementos probatorios. En el caso de las interceptaciones se requiere estar en regla con el art. 15 de la Constitución, y por tanto es una facultad estricta que le asiste a la Fiscalía. ${ }^{89} \mathrm{Con}$ relación a esto encontramos en el art. 43 de la Ley 1621 de 2013, más lo que señala la Corte Constitucional al estudiar este artículo, "deberá sujetarse a estos requerimientos mínimos para garantía del Estado constitucional de derecho y los derechos fundamentales", ${ }^{90}$ refiriéndose a los objetivos y fines que la Ley establece.

88 Ibíd., arts. 3 y 5.

89 Cfr., Corte Constitucional, Sentencia C-540 de 2012, en el apartado referente al art. 17 de la Ley 1621 de 2013.

90 Cfr., Corte Constitucional, Sentencia C-540 de 2012, en el apartado referente al art. 53 del proyecto de Ley., correspondiente al art. 43 de la Ley 1621 de 2013. 
A pesar de que se puede encontrar la distinción conceptual entre el monitoreo y la interceptación, hay casos en que las entidades de inteligencia, ocupadas en el monitoreo, pueden terminar realizando interceptaciones, ya que la distinción consiste en que la "captación incidental” es una revisión del espectro electromagnético, y la interceptación consiste en examinar comunicaciones individualizadas que se pueden adelantar dentro del espectro. El punto es que se puede llegar a desvirtuar que dichas injerencias sean captaciones incidentales en cuanto se demuestre que haya una serie de captaciones a propósito o bajo programa, lo que podría dar base para alegar y probar un seguimiento individual y concreto. ${ }^{91}$ Adicionalmente, el art. 44 hace más difícil hacer esta distinción en cuanto faculta a los organismos de inteligencia para solicitar a los operadores de servicios de telecomunicaciones información sobre teléfonos individualizados y datos técnicos de los suscriptores. Si bien es cierto el mismo artículo señala que las interceptaciones de comunicaciones se desarrollarán en regla al art. 15 constitucional y al CPP, los miembros de inteligencia tendrán de antemano la información sobre teléfonos individualizados y personas concretas.

Otro problema que se encuentra es la filtración de información a los medios de comunicación, como se estudia en la Sentencia T-708 de 2008. En este caso el accionante considera que si no se puede probar que hubo interceptación de

91 Ante esto, el primer caso, de los tres que se expondrán más adelante, hace visible precisamente esta distinción. 
comunicaciones, sino una captación incidental en función del monitoreo del espectro electromagnético, sí encuentra que estas interceptaciones pueden vulnerar el derecho a la intimidad, relacionado con el secreto profesional, en cuanto a la profesión de abogado. Ante esto precisamente, en el art. 33 de la Ley 1621 establece que la información, los documentos, y los elementos técnicos serán de reserva legal por treinta años, extensibles por quince años más. De igual forma, en el art. 17 íbidem establece que la información recolectada que no sea útil para los fines previstos debe ser destruida $y$ no debe ser almacenada en bases de datos.

Con relación al valor probatorio de los informes de inteligencia, estos carecen de tal por su calidad de ser sometidos a reserva legal, según los arts. 33 y 35, aunque puedan servir como criterio orientador de las investigaciones que pueda hacer la Fiscalía en la indagación e investigación, siempre y cuando se garantice la reserva de información, medios, métodos, fuentes e identidad de los funcionarios. Sin embargo, podrían servir como prueba para verificar las actuaciones de los organismos de inteligencia con respecto a sus fines y límites. ${ }^{92}$ Este punto es importante relacionarlo con el último inciso del art. 313 del Decreto 2700 de 1991, adicionado por la Ley 504 de 1999, que consagraba que “[e]n ningún caso los informes de la Policía Judicial y las versiones suministradas por informantes tendrán valor probatorio en el proceso".

92 Cfr., Corte Constitucional, Sentencia C-540 de 2012, referente del art. 35 . 
En este caso, explica la Corte Constitucional en la Sentencia C-392 de 2000 lo siguiente:

La mencionada disposición se ajusta plenamente a la Constitución, en la medida en que no le asigna valor probatorio a los mencionados informes y versiones, por tratarse de actuaciones extraprocesales no controvertidas por las personas a las cuales se podían oponer dentro del proceso.

$[\ldots]$

Sin embargo, lo anterior no obsta para que el funcionario judicial competente pueda, a partir de dichos informes, producir dentro del proceso la prueba que se requiera para establecer la realidad y veracidad de los hechos que son relevantes en éste, la cual naturalmente puede ser controvertida por el sindicado. Pero se anota que lo que dicho funcionario puede valorar es la prueba producida regularmente en el proceso, mas no los mencionados informes. ${ }^{93}$

Así entonces, era posible constituir el elemento material probatorio a partir de testimonio o peritaje de funcionarios de la Policía Judicial, abriendo la posibilidad de que estos fueran controvertidos; a la luz de la Corte Constitucional, los informes de la Policía Judicial no tienen valor probatorio

93 Corte Constitucional, Sentencia C-392 de 2000, referente al art. 50 de la Ley 504 de 1999, que adiciona el último inciso al art. 313 del Decreto 2700 de 1991. 
por no poderse contradecir. Sin embargo, dentro del marco de la Ley 1621 de 2013, por lo pronto, no sería posible constituir elementos probatorios con base en esos informes en cuanto la información que se entrega a la Fiscalía está bajo la condición de reserva legal sobre los diferentes puntos señalados; dicha reserva haría imposible contradecir el informe de los organismos de inteligencia.

Por lo expuesto, se entiende que los organismos de inteligencia y contrainteligencia podrán desarrollar monitoreo del espectro electromagnético y desarrollar captaciones incidentales; si el organismo de inteligencia considera que la información captada es importante y pueda dar información sobre una noticia criminis o como un criterio de orientación para alguna investigación, podrá solicitar información a los operadores de servicios de telecomunicaciones, con las debidas autorizaciones, sobre los teléfonos y los suscriptores. Sin embargo, considerando que no puede desarrollar interceptación de comunicaciones, podrá aportar información y/o documentos, como informes de inteligencia, a la Fiscalía, siempre que esta garantice su reserva en regla a los arts. 33 y 35. Este aporte a la Fiscalía no tendría ningún valor probatorio y solo puede ser utilizado para orientar la indagación. Claramente, la Fiscalía sí podrá adelantar u ordenar la interceptación de comunicación pertinente, y hacerla valer en juicio, siempre y cuando esté en regla con el proceso anteriormente descrito.

A pesar de esto, si se desea que la información o los documentos, generalmente informes de inteligencia, sean introducidos a un proceso penal, primero se debe analizar 
si cumplen con los fines y principios que los rigen, y luego se deben levantar las reservas por el presidente de la República, según el art. 33, parágrafo 1, haciendo que estos sean oponibles, y por tanto se dejaría de cumplir la condición del art. 34. La desclasificación debe ser tanto del documento como de la información, los medios, métodos, fuentes, y el funcionario del organismo de inteligencia por el cual la Fiscalía introducirá el documento al proceso, con el fin de que al momento del juicio se pueda contradecir la prueba. El levantamiento de reserva de todos estos permitiría a la defensa contradecir la prueba, y por tanto tendría validez. Aun así, si la Fiscalía considera que se afecta la seguridad del Estado, podrá decidir no descubrir la prueba según el art. 345, num. 5, del cPp vigente. De esta forma encontramos que los informes de las entidades de inteligencia, para ser aportados a un proceso judicial, tendrán que cumplir todos los requisitos para garantizar la contradicción de la prueba.

\subsubsection{Prueba ilícita, regla de exclusión $y$ prueba derivada}

Es importante resaltar la diferencia entre la inadmisibilidad, el rechazo y la exclusión de pruebas: la inadmisibilidad se predica de aquellos medios de prueba que resultan impertinentes o inconducentes; ${ }^{94}$ el rechazo es "la manera de invalidar elementos de conocimiento probatorio por el incumpli-

94 Novoa Velásquez, Néstor Armando. Nulidades en el procedimiento penal. Actos procesales y acto prueba. Sistemas mixto inquisitivo y mixto acusatorio. Tomo II. Editorial Biblioteca Jurídica Diké, Bogotá, 2011, p. 1030. 
miento de normas relativas al descubrimiento probatorio"; 95 la exclusión se aplica a "aquellos elementos de conocimiento y las pruebas [ilícitas o] ilegales”. ${ }^{96}$ Por otra parte, se diferencia "prueba" que es aquella que se practica en juicio oral y público, donde los sujetos procesales puedan participar de esta, ${ }^{97}$ a lo anteriormente adquirido o compilado como "elementos materiales probatorios" y "evidencia física" 98 e información legalmente obtenida. Se ha debatido que la regla de exclusión del art. 23 del cPp habla de "prueba", en lugar de medios de prueba ofrecidos para que lleguen a ser prueba en el juicio, pero se debe entender que en el lenguaje diario o rápido esos términos se trastocan frecuentemente sin que se justifique derivar de allí consecuencias importantes.

Si revisamos el art. 212 del mismo Código encontramos que el fiscal puede rechazar los elementos materiales probatorios que hayan desconocido "los principios rectores y garantías procesales”. De igual forma, el art. 232 habla de la orden viciada por falta de los requisitos legales en temas de registro y allanamientos, y por ello también se excluye. Por tanto, cuando el art. 23 trae la palabra "prueba”, hace referencia a su sentido amplio, donde abarca los elementos materiales probatorios, evidencias físicas, y medios de prue-

95 Ídem.

96 Cfr., ibíd., p. 1028.

${ }_{97}$ Cfr., Parra Quijano, Jairo. Manual de derecho probatorio. 17. ${ }^{\mathrm{a}}$ ed., Librería ediciones el profesional, Bogotá, 2009, p. 177.

98 Cfr., Corte Suprema de Justicia-Sala de Casación Penal, Sentencia Rad, 39.948, Auto en segunda instancia de 21 de noviembre de 2012. 
ba propiamente dicho dentro del proceso penal, haciendo que la regla de exclusión sea transversal a todo el proceso. ${ }^{99}$

Estas distinciones son importantes en cuanto la escuela alemana ha distinguido dos puntos con respecto a las prohibiciones probatorias: la "producción de evidencias", por una parte, donde se debe cumplir el procedimiento establecido buscando garantizar los derechos del investigado, y por otra parte, con posterioridad de la producción, se estudia el uso judicial que tendrán las evidencias en el razonamiento del juez. ${ }^{100}$

En el proceso de la Ley 906, el momento central para la solicitud y declaración de exclusión es la audiencia preparatoria, en la que se puede debatir la forma en que se produjeron los elementos probatorios y la evidencia testimonial ofrecida. Aquellos medios que llegan a la audiencia preparatoria, a menos que se encuentren con alguna ilegalidad o ilicitud, se decretarán para ser practicados en el juicio oral. Después de la práctica probatoria, ya con las pruebas propiamente dichas, se revisa cuál puede ser el uso judicial que tienen al momento de tomar una decisión. La regla de exclusión se enfoca en la forma en que se producen los elementos probatorios; si estos, después de practicados, tienen

99 Cfr., Daza González, Alfonso Evidencia ilegal, evidencia ilícita y regla de exclusión. En: Revista Derecho Penal Contemporáneo (n. $\left.{ }^{\circ} 27\right)$. ISSN: $1692-$ 168. Editorial Legis, Bogotá (abril-junio), 2009.

100 Cfr., Guerrero Peralta, Óscar Julián. Las probibiciones de prueba en el proceso penal colombiano. Anotaciones desde el derecho comparado. En: Beling, Ernst y otros. Las prohibiciones probatorias. Editorial Temis S. A, Bogotá, 2009, pp. 155, 156. 
algún uso judicial, al resultar excluidos se puede afectar la ratio de la sentencia. ${ }^{101}$ Siguiendo a la Corte Suprema de Justicia, "[e]l juicio de legalidad se relaciona con el proceso de formación de la prueba, con las normas que regulan la manera de producir e incorporar la prueba al proceso, con el principio de legalidad en materia probatoria y la observancia de los presupuestos y las formalidades exigidas para cada medio". ${ }^{102}$

Así las cosas, encontramos que la correcta producción probatoria está en cabeza de la Fiscalía en cuanto ella tiene el deber de revisar el cumplimiento del debido proceso, como también del juez de control de garantías, el juez de conocimiento, y el juez de segunda instancia cuando conoce de las apelaciones por la admisión, rechazo o exclusión de material probatorio en la audiencia preparatoria. Con relación al uso judicial, el primer control es del juez de conocimiento dado que es el primero en apreciar la prueba, tanto individual como conjuntamente con las demás pruebas; seguidamente están los controles por el recurso de apelación ante el superior, el recurso de casación ante la Corte Suprema de Justicia, y eventualmente por los jueces en la acción de tutela que puede llegar hasta la Corte Constitucional.

101 Cfr., ibíd., pp.155-157.

102 Corte Suprema de Justicia-Sala de Casación Penal, Rad. 29.853, Sentencia de 20 de agosto de 2008. 


\subsubsection{Prueba ilícita y regla de exclusión}

El art. 29 constitucional sanciona la violación del debido proceso y los derechos fundamentales, con la declaración de nulidad de pleno derecho de las pruebas así afectadas. ${ }^{103}$ Este tipo de prueba se conoce como ilícita. El profesor Jairo Parra Quijano resalta el concepto de Ada Pellegrini: "Por prueba ilícita en sentido estricto, indicaremos por tanto la prueba recogida infringiendo normas o principios colocados por la constitución, frecuentemente para protección de las libertades públicas y los derechos de la personalidad y de su manifestación como el derecho a la intimidad". ${ }^{104}$

Hay diferentes calificaciones de prueba, pero sobre aquella que se relaciona con el principio de licitud, encontramos los tres siguientes: primero, la "prueba ilícita, que como ya se dijo, viola derechos fundamentales, sea que esa violación se haya cometido para conseguir la fuente, o el medio probatorio. La prueba ilegal, es decir, aquella que viola una norma legal. Y la prueba irregular desde el punto de vista procesal" enfocandonos en las dos primeras. ${ }^{105} \mathrm{La}$

103 Cfr., Parra Quijano, Jairo. Op. cit., p. 24, citando a: Pellegrini, Ada. Revista de la asociación de ciencias penales de Costa Rica. Año 7, n. ${ }^{\circ} 10$, septiembre de 1995. El profesor Parra Quijano la define de la siguiente manera: "La prueba ilícita es aquella que se obtiene violando derechos fundamentales de las personas, bien haya sido para lograr la fuente de prueba o bien para lograr el medio probatorio, y su proscripción es consecuencia de la posición preferente de los derechos fundamentales en el ordenamiento y de su afirmada condición de inviolables" (Parra Quijano, Jairo. Op. cit., p. 20).

104 Ibíd., p. 24, citando a: Pellegrini, Ada. Revista de la asociación de ciencias penales de Costa Rica. Año 7, n. ${ }^{\circ}$ 10, septiembre de 1995.

105 Ibíd., p. 23. Cfr., Corte Constitucional, Sentencia SU-159 de 2002. Hay que hacer la salvedad de que la Corte Constitucional en dicha sentencia hace la 
Corte Suprema de Justicia ha entendido la distinción entre prueba ilícita y prueba ilegal de la siguiente manera:

Se entiende por prueba ilícita la que se obtiene con vulneración de los derechos fundamentales de las personas, entre ellos la dignidad, el debido proceso, la intimidad, la no autoincriminación, la solidaridad íntima; y aquellas en cuya producción, práctica o aducción se somete a las personas a torturas, tratos crueles, inhumanos o degradantes, sea cual fuere el género o la especie de la prueba así obtenida.

$[\ldots]$

La prueba ilegal se genera cuando en su producción, práctica o aducción se incumplen los requisitos legales esenciales, caso en el cual debe ser excluida, como lo indica el artículo 29 Superior. ${ }^{106}$

Esta clasificación es importante dado que configura el supuesto de hecho de la regla de exclusión, y como regla, a

distinción entre prueba inconstitucional y prueba ilícita; posteriormente cambia a la calificación que conocemos entre prueba ilícita (constitucional) y prueba ilegal (ilícita).

106 Corte Suprema de Justicia-Sala de Casación Penal, Sentencia Rad. 31.073 , Sentencia de $1 .^{\circ}$ de julio de 2009. Estos párrafos se han venido repitiendo constantemente a lo largo de los diferentes procedimientos: en relación con el proceso Ley 906, encontramos la sentencia citada; en el proceso Ley 600, lo encontramos en la Corte Suprema de Justicia-Sala de Casación Penal, Sentencia Rad. 21.529, Sentencia de 7 de septiembre de 2006; y en relación con el proceso Decreto 2700 de 1991, en la Corte Suprema de Justicia-Sala de Casación Penal, Sentencia Rad. 18.451, Sentencia de 8 de julio de 2004, y Rad. 18103 del 2 de marzo de 2005. 
un supuesto de hecho procede una sanción. ${ }^{107}$ El supuesto de hecho, o la fuente de exclusión - como lo llama la jurisprudencia - , se basa precisamente en la anterior calificación de prueba ilícita y prueba ilegal, principalmente. La sanción consistirá, según el art. 29, en que la prueba obtenida por alguna de las dos fuentes se declarará como nula de pleno derecho. Esta se conoce como regla constitucional de exclusión, y ha tenido desarrollo en las diferentes áreas del derecho. ${ }^{108}$

La clasificación de prueba ilícita y prueba ilegal se ve reflejada en dos reglas de exclusión dentro del CPP. Lo referente a la prueba ilícita se ha desarrollado en el art. 23 del código vigente, que dice: “Toda prueba obtenida con violación de las garantías fundamentales será nula de pleno derecho, por lo que deberá excluirse de la actuación procesal". Y con relación a la prueba ilegal, su exclusión la encontramos en los arts. 359 y 360 del mismo código. El último reza: “El juez excluirá la práctica o aducción de medios de prueba ilegales, incluyendo los que se han practicado, aducido o conseguido con violación de los requisitos formales previstos en este código". El desarrollo de la jurisprudencia gira a partir del art. 23 del CPP y este se relaciona con el art. 29 constitucional, pero no se deben dejar de lado los arts. 359 y 360, donde se pueden encontrar elementos relacionados con la legalidad, admisibilidad, autenticidad, credibilidad y relevancia.

107 Cfr., Quinche Ramírez, Manuel Fernando. Op. cit., pp. 65, 66.

108 Cfr., Corte Constitucional, Sentencia su-159 de 2002. 
La exclusión del art. 23 tiene relación con los derechos y garantías fundamentales y por ello se encuentra dentro del Título preliminar de principios y garantías fundamentales. La exclusión del art. 360 se encuentra dentro Título del CPP que regula la audiencia preparatoria; de tal manera, pareciera ser que esta exclusión solo sería aplicable en dicha audiencia, y pasada esta ya no se podría aplicar, en cuanto los momentos procesales son perentorios. Sin embargo, el art. 177, num. 5 establece que se concederá la apelación en el efecto suspensivo contra el auto que decide sobre la exclusión de una prueba del juicio oral; por lo tanto, también en el curso del juicio se puede proponer y decidir esa exclusión. Retomando la prueba ilícita, el art. 29, inc. 5 constitucional dice " $[\mathrm{e}] \mathrm{s}$ nula, de pleno derecho, la prueba obtenida con violación del debido proceso". ${ }^{109}$ En este inciso se entiende que debido proceso "no comprende exclusivamente las garantías enunciadas en el art. 29 de la Constitución sino todos los derechos constitucionales fundamentales". ${ }^{110}$ Por esta razón, el profesor Parra Quijano dice que hay una interpretación no solo formal, sino también material de la expresión

109 Hay que tener en cuenta que tanto la primera como la cuarta comisión de la Asamblea Constituyente trataron la nulidad por violación de derechos y garantías en la constitución, y en la Comisión Accidental para conciliar ambos textos se adicionó la nulidad de pleno derecho al establecer que "(i) la nulidad se genera no sólo cuando hay torturas o tratos inhumanos o degradantes, sino ante cualquier violación de los derechos y garantías establecidos en la Constitución y (ii) la nulidad no se predicaría solo de declaraciones, sino también de cualquier otro medio de prueba"; Cfr., Corte Constitucional, Sentencia SU159 de 2002. Citando a: Antecedentes del artículo 29 en la Asamblea Nacional Constituyente. Biblioteca de la Corte Constitucional, folio 190.

110 Corte Constitucional, Sentencia su-159 de 2002. 
"debido proceso". ${ }^{111}$ Relacionando esto con la calificación anteriormente dada, la prueba ilegal tiene que ver más con el debido proceso formal, mientras que la prueba ilícita se vincula con el debido proceso material o sustancial. ${ }^{112}$ Los efectos de esta distinción consisten en que la prueba ilegal puede ser ponderada con respecto a su vicio, y si se considera que este no es esencial puede no ser excluida, mientras que la prueba ilícita genera una exclusión automática. Cabe la ponderación solo con respecto a las pruebas derivadas. ${ }^{113}$

Generalmente, la nulidad de pleno derecho se decreta sobre las pruebas, no sobre el proceso, de manera que solo se excluye la prueba y el proceso sigue su curso. ${ }^{114} \mathrm{Sin}$ embargo, la Sentencia C-591 de 2005 prevé que se decretará la nulidad de todo el proceso cuando para la obtención de la evidencia se cometan crímenes como tortura, desaparición forzada o ejecución extrajudicial, por ser crímenes de lesa humanidad imputables a agentes del Estado. ${ }^{115}$

111 Cfr., Parra Quijano, Jairo. Op. cit., p. 23.

112 Cfr., Corte Constitucional, Sentencia T-233 de 2007.

113 Cfr., Corte Suprema de Justicia-Sala de Casación Penal, Sentencia Rad. 31.073, Sentencia de 21 de julio de 2009.

114 Cfr., Corte Constitucional, sentencias T-916 de 2008, T-233 de 2007, C-210 de 2007, SU-159 de 2002, C-372 de 1997.

115 Cfr., Corte Constitucional, Sentencia C-591 de 2005. Ante este punto consideramos que hay yerro entre los delitos enlistados y el concepto de lesa humanidad, considerando que estos delitos se pueden cometer sin que sean crímenes de lesa humanidad, dado que para estos se requiere un criterio de sistematicidad o generalidad. Sin embargo, a pesar de lo que establece en la parte considerativa, el Resuelve de la Corte no repite que sean de lesa humanidad, sino que enlista los delitos. Cfr., Corte Constitucional, Sentencia C-210 de 2007. La Corte Suprema de Justicia-Sala de Casación Penal, Sentencia Rad. 
Se han venido estableciendo cinco supuestos para que proceda la regla de exclusión: ${ }^{116}$

\section{Cuando}

se está ante una ilegalidad que compromete el debido proceso, bien sea cuando se han afectado las reglas sustantivas que protegen la integridad del sistema judicial o que buscan impedir que se tomen decisiones arbitrarias, o bien sea cuando han sido desconocidas formalidades esenciales que aseguran la confiabilidad de la prueba y su valor para demostrar la verdad real dentro del proceso penal. ${ }^{117}$

De tal manera, "no toda irregularidad en el decreto, práctica y valoración probatoria, implica automáticamente afectación del debido proceso". ${ }^{118}$ Esto hace que el juez analice el alcance de la irregularidad, y si resulta o no necesaria su exclusión.

2. Relacionado con la distinción de prueba ilícita y prueba ilegal, se debe revisar el alcance del debido proceso, es decir, "si se refiere exclusivamente a las

33621 del 10 de marzo de 2010, aplicó dicha regla en un caso donde se relatan torturas cometidas por agentes de la Sijín; la Corte decide declarar la nulidad del proceso desde la resolución de apertura de investigación.

116 Cfr., Quinche Ramírez, Manuel Fernando. Derecho constitucional colombiano... Op. cit., p. 216.

117 Corte Constitucional, Sentencia su-159 de 2002.

118 Cfr., Corte Constitucional, Sentencia T-916 de 2008. 
reglas procesales o si también incluye las que regulan la limitación de cualquier derecho fundamental”. ${ }^{119}$ La importancia radica en que en caso de una prueba ilegal, esta se pueda subsanar, y en el caso en que no se subsane conllevaría a una violación al debido proceso formal y con ello su exclusión. ${ }^{120}$

3. En el caso del debido proceso material,

la decisión de excluir una prueba incide no sólo en el respeto a las garantías de imparcialidad, debido proceso, y derecho de defensa, sino, además, en el goce efectivo de otros derechos constitucionales, tales como la vida, la integridad y libertad, protegidos por el legislador mediante la sanción de quienes violen el Código Penal. ${ }^{121}$

En este caso, simplemente no existe forma de subsanar la prueba y por tanto deberá ser excluida.

4. "[E]l mandato constitucional de exclusión de las pruebas obtenidas con violación al debido proceso exige que el funcionario judicial de manera expresa determine que la prueba viciada no puede continuar formando parte del expediente". ${ }^{122}$ Esto garantiza que el juez decida de fondo sobre la decisión de excluir

119 Corte Constitucional, Sentencia su-159 de 2002.

120 Cfr., Parra Quijano, Jairo. Op. cit., p. 23.

121 Corte Constitucional, Sentencia su-159 de 2002. Ídem. 
la prueba, asegurando que no haya una exclusión probatoria arbitraria.

5. Finalmente, la Corte Constitucional en el Resuelve de la Sentencia C-591 de 2005, establece la regla de que si una prueba se consigue por medio de una tortura, una desaparición forzada o una ejecución extrajudicial, se declarará la nulidad de todo el proceso si se prueba que esta conducta le es imputable a un agente del Estado.

Por lo anterior, la regla de exclusión del art. 360 se enfoca principalmente en los dos primeros supuestos. ${ }^{123}$ Sin embargo, aquellas pruebas ilegales que tienen un alcance sobre un derecho fundamental pueden llegar a ser consideradas como pruebas ilícitas, y se genera su exclusión. Los supuestos del tercero al quinto tienen una relación directa con el art. 23 del CPP, lo cual genera su exclusión e incluso la nulidad de todo el proceso, tal como señala el último supuesto. Acorde con esto, podemos decir que la prueba ilegal y la prueba ilícita cumplen con dos estándares de prueba diferentes: el primero parte desde el debido proceso formal, muy relacionado con las reglas procesales; y el segundo vincula el debido proceso material con los derechos fundamentales, sin perder de vista que una violación grave al debido proceso formal puede

123 Este tipo de prueba es lo que Parra Quijano llama “prueba irregular", en cuanto que sí hay una violación de una norma estrictamente procesal, pero no tiene mayor alcance a la garantía del procesado. Cfr., Parra Quijano, Jairo. Op. cit., p. 23. 
llegar a afectar otros derechos, y por tanto también sería cobijado por el art. 23 de CPP.

La regla de exclusión termina siendo entonces una garantía de protección de derechos, al condicionar la producción probatoria; y en caso de que se haya practicado, se prohíbe su uso judicial. Los deberes que tiene el Estado con base en el art. 2 no se pueden convertir en una razón para cometer actos violatorios de los derechos humanos, negando sus propios pilares. ${ }^{124} \mathrm{La}$ jurisprudencia considera que la regla de exclusión cumple estas funciones:

Nuestro ordenamiento jurídico acoge así, con éste régimen de exclusión de la prueba constitucionalmente ilícita, el cumplimiento de una función disuasiva, en relación con la conducta futura de las autoridades, especialmente de las de policía judicial, protectora en cuanto a la integridad del sistema constitucional y judicial, de garantía de los principios y reglas del Estado social de derecho, aseguradora de la confiabilidad y credibilidad del sistema probatorio y, eventualmente, reparadora de los perjuicios causados al procesado con una arbitrariedad"125 (negrillas originales del texto).

${ }^{124}$ Cfr., Corte Suprema de Justicia-Sala de Casación Penal, Sentencia Rad. 33.621, Sentencia de 10 de marzo de 2010.

125 Corte Suprema de Justicia-Sala de Casación Penal, Sentencia Rad. 18.451, Sentencia de 8 de julio de 2004, citando a: Corte Constitucional, Sentencia SU-159 de 2002; Cfr., Parra Quijano, Jairo. Op. cit., p. 34. 
Encontramos que la regla de exclusión, por deber del Estado de proteger garantías fundamentales, permite su aplicación en cualquier momento procesal. ${ }^{126}$ En caso de que una decisión judicial se encuentre en apelación, casación, o tutela por vía de hecho, y termine excluyendo una prueba ilícita determinante para la decisión, como habíamos dicho antes, se declarará la nulidad del proceso hasta la práctica de pruebas por violación al principio de congruencia. ${ }^{127}$

\subsubsection{Prueba derivada y sus excepciones en la regla de exclusión}

Resulta necesario hacer una breve mención sobre la prueba derivada teniendo en cuenta que a partir de una prueba ilícita se pueden generar muchas otras en el transcurso de la investigación penal. Las pruebas derivadas de las que se alega exclusión son aquellas que si bien son legales según la forma de producción, se basan en datos obtenidos por una primera prueba ilícita, o prueba base, donde hay una relación de causa-efecto entre la prueba base y la prueba derivada; haciendo analogía con un árbol, el tronco sería la prueba base, y las ramificaciones y sus frutos serían las pruebas derivadas. Cuando la prueba base es ilícita o ilegal termina afectando la relación causal de las pruebas derivadas, de tal manera que "al restarle mérito a la prueba ilegalmente obtenida afecta a aquellas pruebas que si bien son en sí mismas legales, no obstante están basadas en datos conseguidos por aquella prueba

126 Cfr., Corte Constitucional, Sentencia C-591 de 2005.

127 Cfr., ibíd., n. 96, 97. 
ilegal, llegándose a concluir que tampoco esas pruebas legales pueden ser admitidas”. ${ }^{128}$ En la analogía, la prueba ilícita envenena el árbol y con ello su fruto, de ahí su nombre: teoría de los frutos del árbol envenenado. Acorde con lo anterior, el art. 23, inciso segundo, ordena que la prueba derivada también sea excluida del expediente: "Igual tratamiento recibirán las pruebas que sean consecuencia de las pruebas excluidas, o las que solo puedan explicarse en razón de su existencia”.

Sin embargo, la jurisprudencia norteamericana, principalmente, ha desarrollado diferentes excepciones para su aplicación. Entre esas el CPP ha tomado tres que señala el art. 455: "Art. 455. Nulidad Derivada de la prueba ilícita. Para los efectos del artículo 23 se deben considerar, al respecto, los siguientes criterios: el vínculo atenuado, la fuente independiente, el descubrimiento inevitable y los demás que establezca la ley".

Podemos entender la fuente independiente como "aquella que no tiene conexión causal con la prueba ilícita original, por lo cual, si al conocimiento de los hechos se llega por una prueba lícita sin relación causal con la ilícita que trata sobre los mismos hechos, entonces aquella prueba lícita no es alcanzada por la regla de exclusión”. ${ }^{129}$ En otras palabras,

128 Parra Quijano, Jairo. Op. cit., p. 33.

129 Corte Suprema de Justicia-Sala de Casación Penal, Rad. 23.284, Sentencia de 5 de octubre de 2006, citando a: Jauchen, Eduardo. Tratado de la prueba en materia penal. Editorial Rubinzal-Culzoni. Buenos Aires, 2004, p. 646. 
la prueba derivada no tiene ninguna relación causal con la prueba ilícita, y por tanto esta no sería excluida. ${ }^{130}$

El descubrimiento inevitable consiste en que "cuando, dadas las circunstancias, a pesar de la ilegalidad, es viable deducir sin duda que la prueba hubiera sido obtenida lo mismo por otro medio legítimo". ${ }^{131}$ Se ha venido entendiendo esta como una extensión de la fuente independiente, como lo ha entendido la Suprema Corte de Estados Unidos: "[d]ado que la evidencia viciada hubiera sido admisible si era efectivamente descubierta a través de una fuente independiente, debería ser admisible si hubiese sido descubierta en forma inevitable"132. Sin embargo, como señala Guerrero Peralta, esta excepción ha tenido críticas dado que se discuten temas como qué tanto tiempo transcurriría para el descubrimiento de la prueba y realmente qué tan inevitable sería el descubrimiento, como se planteó en el caso norteamericano Nix vs. Williams. ${ }^{133}$

Ante el vínculo atenuado, este "se ha entendido que si el nexo existente entre la prueba ilícita y la derivada es tenue, entonces la segunda es admisible atendiendo al principio de la buena fe, como quiera que el vínculo entre ambas

130 Cfr., Guerrero Peralta, Óscar Julián. Institutos probatorios del nuevo proceso penal. Ediciones Nueva Jurídica. 1. a ed., Bogotá, 2009, pp. 257-262. Vale la pena comentar que si no tiene ninguna relación causal, la prueba tampoco podría ser derivada.

131 Corte Suprema de Justicia-Sala de Casación Penal, Rad. 23.284, Sentencia de 5 de octubre de 2006.

132 Guerrero Peralta, Óscar Julián. Institutos probatorios... Op. cit., p. 264, citando a: Murray vs. United States 487 U.S. 539, 1988.

133 Cfr., ibíd., p. 267-272. 
pruebas resulta ser tan tenue que casi se diluye el nexo de causalidad". ${ }^{134}$ Si bien esta excepción se desarrolla principalmente en la jurisprudencia americana, deja muchos vacíos. El problema principalmente consiste en no tener claridad de cómo se atenúa dicha prueba según nuestras propias reglas. En nuestra percepción, vemos que el mejor ejemplo del vínculo atenuado es la utilización de la información obtenida por entidades de inteligencia; por ejemplo, mediante interceptaciones de comunicaciones no desarrolladas estrictamente dentro de los parámetros legales, si bien no es posible usarla en el proceso penal, sí puede ser usada como criterio orientador de una investigación penal, de manera que las informaciones derivadas y evidencia no necesariamente se vinculan con el origen irregular.

En el caso hipotético de que a una prueba aparentemente ilícita se le logre probar alguna de estas excepciones, la prueba deberá ser admitida dentro del proceso judicial. Pero a pesar del desarrollo legal, jurisprudencial y doctrinal, no resulta fácil encontrar ejemplos prácticos, por lo que a nuestro modo de ver, para explicar el vínculo atenuado es útil el de la información obtenida por las entidades de inteligencia, pero esta no se lleva ordinariamente al juicio.

134 Corte Suprema de Justicia-Sala de Casación Penal, Rad. 23.284, Sentencia de 5 de octubre de 2006, citando a: Corte Constitucional, Sentencia C-591 de 2005. 


\section{Conclusiones: aplicación de lo expuesto en los tres casos}

En resumen, encontramos que el modelo de Estado termina por defender la forma de un proceso y de un procedimiento judicial. En Colombia, por ser un Estado social de derecho, el ordenamiento incluye la dignidad humana como un pilar fundamental. La dignidad humana no se puede entender de manera aislada, sino que se estudia en relación con otros derechos humanos que permiten su manifestación, como es el caso del derecho a la intimidad. Este derecho no solo permite la tranquilidad de poderse manifestar sin una intervención no consentida, sino que además protege la relación entre personas y grupos. La manifestación de poder reunirse y comunicarse entre personas o grupos sin tener ninguna injerencia como regla general es un aspecto básico para el desarrollo de la democracia.

Pero por otra parte, el Estado también tiene el deber de perseguir los delitos, como una manifestación del art. 2 constitucional; por tal razón, hay momentos donde resulta necesario realizar injerencias en la privacidad de la persona, como es el caso de las interceptaciones de comunicaciones. Si bien es una injerencia al derecho a la intimidad, dicha excepción se encuentra regulada constitucional y legalmente, exigiéndose autorización judicial para hacerla. Al considerar que se requiere autorización judicial y que dicha autorización debe estar reglada por la Constitución y la Ley, se termina relacionando con el debido proceso, tanto material como formal. Solo a partir del cumplimiento de los ritos tal 
como lo establecen el CPP y las reglamentaciones propias de la Fiscalía, podrá darse una interceptación de comunicaciones lícitamente.

En el caso en que se realice sin autorización, por más loable que sea la razón, dicha prueba se considerará ilícita y por tanto deberá declararse su exclusión del proceso, así como también las pruebas derivadas de esta, salvo las tres excepciones para evaluar hasta dónde se extiende la ilicitud. La regla de exclusión es una garantía procesal para la protección de los derechos humanos en cuanto condiciona la producción probatoria y su uso judicial, y es aplicable en cualquier momento procesal, pudiendo emplear los diferentes recursos y mecanismos legales y constitucionales. Esa regla, al usarse en el proceso, si bien recae principalmente sobre la prueba, puede llevar a su nulidad cuando: primero, al excluir la prueba de una sentencia que haya sido esencial para establecer la condena, esta se vuelve insostenible, y por tanto se declara la nulidad hasta el momento de la práctica probatoria por violación al principio de congruencia probatoria; o segundo, siendo el supuesto más grave, si la prueba se obtuvo a partir de una tortura, desaparición forzada o ejecución extrajudicial, se declara la nulidad total de proceso y necesariamente se cambia el juez que haya tenido conocimiento.

Sin embargo, es interesante ver cómo la Fiscalía, a pesar de que se haya pasado de un sistema mixto con rasgos inquisitivos a otro con preponderancia acusatoria, necesitaba antes la autorización previa de otro funcionario para desarrollar la interceptación, ya fuera por el Fiscal delegado o 
por la Dirección Nacional de la Fiscalía, aunque fuera dentro de la misma entidad; sorpresivamente, al pasar a un sistema acusatorio no se requiere autorización previa para la primera orden sino que se hace un revisión posterior a la injerencia.

De igual forma, resulta llamativo ver la regulación de la actividad de inteligencia, que le permite monitorear el espectro electromagnético y adelantar captaciones incidentales; aunque estas captaciones son lícitas, y por regla general no tienen valor probatorio, siguen siendo una injerencia a la intimidad personal. Pero en los tres casos expuestos encontramos que estas fueron utilizadas en procesos judiciales y fueron claves para la condena de los procesados, claramente antes de la Ley 1621 de 2013.

1. En el caso de Juan Carlos Castillo las pruebas obtenidas por la RIME 4 son excluidas, y se usan las interceptaciones del CTI. A pesar de ello es importante resaltar que el Ejército sí tuvo la capacidad de adelantar interceptaciones de comunicaciones en cuanto su armamento estaba siendo vendido a otros sujetos de conflicto armado y bandas delincuenciales. De igual forma, considera que es un buen caso para explicar el "vínculo atenuado", puesto que aunque a la luz del Tribunal Superior de Bogotá son injerencias indebidas, por mandato legal estas sí pueden ayudar a orientar la investigación penal. Es importante resaltar que a pesar de que se pudo llegar a la condena del señor Castillo, la investigación presentó varios inconvenientes puesto que el CTI tuvo que modificar 
su plan de investigación al encontrar que las líneas ya estaban siendo interceptadas por la RIME 4, y cuando solicitó la interceptación de líneas diferentes también se encontró que algunas ya lo estaban. A pesar de su exclusión probatoria, tanto la investigación del CTI como de la RIME 4, contenían la misma información, solamente que el primero tuvo mayor desgaste mientras readaptaba su estrategia de investigación.

2. En el caso de la masacre de Macayepo, la sipol captó la conversación de Álvaro García Romero y Joaquín García Rodríguez, siendo así la prueba fundamental por la cual se demuestra la responsabilidad de Morris Taboada y García Romero. Si bien el análisis que plantea la Corte Suprema de Justicia tiene sustento en la sentencia de la Corte Constitucional, por lo cual se estudia el último inciso del art. 313 del Decreto 2700 de 1991, se cumplió el principio de contradicción y satisface los requisitos de relevancia y credibilidad, pero no satisface el criterio constitucional de que solamente se pueden hacer injerencias a la intimidad por autorización judicial. Es decir, si la prueba se observa desde el punto de vista de la prueba ilegal, esta cumple el estándar, pero desde el punto de vista de la prueba ilícita no lo cumple. También resaltamos que si hubiera estado rigiendo la Ley 1621 de 2013 para la fecha de los hechos, no tendrían ningún valor probatorio, al menos que se levantaran las reservas legales. 
3. En el caso de la toma del Palacio de Justicia, las captaciones incidentales por radioaficionados y aportadas por periodistas de Radio Todelar, sí hay varios cuestionamientos, siguiendo el salvamento de voto. Desde el enfoque de la prueba ilegal, hay dudas con respecto a la credibilidad, así como algunas divergencias al contradecirse los autores de estas. Desde la prueba ilícita, hay una contradicción entre lo que plantea la parte considerativa de la sentencia al decir que es una actitud loable de los ciudadanos, y el precedente de la Corte Constitucional en el sentido de que en ningún caso, por más buena intención que se tenga, podrán ser admitidas las injerencias ilícitas en las comunicaciones; a esto se le suma el salvamento de voto, que con respecto al señor Montaña, encuentra creíble la intención ilegal de interceptar las comunicaciones de los miembros del Ejército, dado que la frecuencia en la que ellos se comunicaban estaba por fuera de los rangos permitidos según lo reglamentado por el Ministerio de Comunicaciones para los radioaficionados y uso civil. De tal manera, pareciera que las interceptaciones no cumplen con los estándares de prueba, tanto de la prueba ilegal como de la prueba ilícita.

Encontramos una tensión entre las captaciones de organismos de inteligencia y de interceptaciones por terceros usadas como prueba en los procesos judiciales, contra la regla de 
exclusión del art. 23 del cPp en concordancia con el derecho a la intimidad. Es innegable la importancia de estas interceptaciones y captaciones para demostrar la responsabilidad penal, y más aún cuando son casos que están relacionados con el armamento de guerrillas o paramilitares, o una masacre contra la población civil, o la toma al Palacio de Justicia. Estas captaciones incidentales, ya sea por los miembros de inteligencia o por particulares, como sucedió en la toma del Palacio, van en contra de la regla constitucional de que estas injerencias requieren orden de la Fiscalía, entendida como una autoridad judicial, y aun así, a la luz del cpp vigente, se requeriría control posterior. Así, encontramos que si bien es una actividad legal en cuanto es permitida por una Ley - y con ello podría argumentarse que a la luz del estándar de la legalidad es factible-, es posible que a la luz de los mandamientos constitucionales pueda haber una tensión y por tanto el punto de debate está en si estas actividades pueden llegar a ser constitucionales o lícitas. 


\section{Capítulo segundo Licitud de injerencias de comunicaciones en el derecho internacional humanitario y derecho internacional de los derechos humanos}

\section{Introducción}

El objeto de este capítulo es mostrar cómo desde el derecho internacional humanitario (DIH) se podrían tratar las injerencias en las comunicaciones privadas, principalmente las interceptaciones dentro de un contexto de conflicto armado no internacional, para después contrastarlas con el manejo interno. Así mismo, teniendo en cuenta nuestro contexto nacional, resulta necesario entender la relación del DIH con el derecho internacional de los derechos humanos (DIDH), para luego exponer cuál ha sido el desarrollo dentro del DIDH sobre esta misma materia.

\subsection{Las interceptaciones de comunicaciones a la luz del DIH}

En este punto nos vamos a concentrar en cómo se podrían tratar las interceptaciones de comunicación en esta rama del derecho internacional. Para ello expondremos la definición vigente de conflicto armado, luego expondremos sus 
principios y con base en ello daremos una respuesta sobre el asunto que nos concierne.

\subsection{Definición de conflicto armado}

La definición jurídica de conflicto armado como propiamente se conoce hoy día la encontramos en la Decisión de Apelación sobre la Jurisdicción del Tribunal Internacional para la ex-Yugoslavia (TPIY) en el caso Tadic, que dice: "Existe un conflicto armado siempre que se recurre a la fuerza armada entre Estados, o a la violencia armada prolongada entre autoridades gubernamentales y grupos armados organizados o entre tales grupos dentro de un Estado". ${ }^{1,2}$

1 TPIY, Sala de Apelaciones, Prosecutor v. Dusko Tadic. Decision on the defence motion for interlocutory appeal on jurisdiction (IT-94-1-A), de 2 de octubre de 1995, párr. 70. (Traducción libre) Dice textualmente: "We find that an armed conflict exists whenever there is a resort to armed force between States or protracted armed violence between governmental authorities and organized armed groups or between such groups within a State"; Cfr., CPI, Situación de la República Democrática del Congo, Sala de Primera Instancia I, Prosecutor v. Thomas Lubanga Dyilo. Judgment pursuant to Article 74 of the Statute (ICC01/04-01/06) de 14 de marzo de 2012, párr. 533.

2 Claramente el "conflicto armado" tiene otra palabra en el lenguaje común, que es "guerra”. La Real Academia de la Lengua la entiende, en su segunda acepción, como la "[L]ucha armada entre dos o más naciones o entre bandos de una misma nación”. Otra definición la encontramos en uno de los textos clásicos sobre esta materia: Carl Von Clausewitz dice que "[l]a guerra es pues un acto de violencia para obligar al contrario a hacer nuestra voluntad”. Cfr., Von Clausewitz, Carl. De la guerra. Editorial La Esfera de los Libros. Versión íntegra, Madrid, 2005, p. 17.

Para el entendimiento de los conflictos es bueno estudiar cuáles podrían ser los “mitos de origen” para darles un sentido o una explicación, como lo es "el Eelam para los tamiles, Marquetalia para las FARC, y la Irlanda Unida para el IRA", puesto que a partir del entendimiento razonado de sus causas, y viendo lo que hay detrás de los mitos, se puede hacer un mejor análisis del contexto. Cfr., 
Con base en este concepto, se han reconocido principalmente tres tipos de conflictos, los que la CPI los ha venido definiendo de la siguiente manera: i) conflicto armado internacional: "[e]xiste un conflicto armado internacional en el caso de las hostilidades armadas entre los Estados a través de sus respectivas fuerzas armadas $\mathrm{u}$ otros actores que actúan en nombre del Estado"; 3 ii) conflicto armado no internacional; consiste en que "la participación de los grupos armados con cierto grado de organización y la capacidad de planificar y llevar a cabo operaciones militares sostenidas permitiría que el conflicto se caracterizara por ser un conflicto armado que no sea de índole internacional"; ${ }^{4} \mathrm{y}$

Uribe Alarcón, Maria Victoria. Salvo el poder, todo es ilusión. Mitos de origen: Tigres Tamiles de Sri Lanka, Fuerzas Armadas de Colombia, Irish Rupublican Army. Instituto Pensar, Universidad Pontifica Javeriana. Bogotá, 2007, pp. 26-31.

3 CPI, Situación República Democrática del Congo. Sala de Primera Instancia I, Prosecutor v. Thomas Lubanga Dyilo. Judgment pursuant to Article 74 of the Statute (ICC-01/04-01/06) de 14 de marzo de 2012, párr. 541. (Traducción libre) Dice textualmente: "an international armed conflict exists in case of armed hostilities between States through their respective armed forces or other actors acting on behalf of the State", citando a: CPI, Sala de Cuestiones Preliminares II, Caso Prosecutor v. Jean-Pierre Bemba Gombo. Decision Pursuant to Article 61(7)(a) and (b) of the Rome Statute on the Charges of the Prosecutor Against Jean-Pierre Bemba Gombo (ICC-01/05-01/08-424) de 15 de junio de 2009, párr. 223.

4 CPI, Situación de la República Democrática del Congo. Sala de Primera Instancia I, Prosecutor v. Thomas Lubanga Dyilo. Judgment pursuant to Article 74 of the Statute (ICC-01/04-01/06) de 14 de marzo de 2012, párr. 535. (Traducción libre) Dice textualmente: "the involvement of armed groups with some degree of organisation and the ability to plan and carry out sustained military operations would allow for the conflict to be characterised as an armed conflict not of an international character", citando a: CPI, Situación de la República del Congo, Sala de Cuestiones Preliminares I, Prosecutor v. Thomas Lubanga 
iii) el que la doctrina ha venido llamando conflicto armado internacionalizado, el cual es una combinación de los dos anteriores. Se presenta cuando un Estado interviene directamente en apoyo de un grupo armado organizado que se opone a las fuerzas gubernamentales, ${ }^{5}$ o cuando un Estado tiene dominio sobre un grupo armado dentro de un Estado diferente, tiene "un papel en la organización, coordinación y planificación de las acciones militares del grupo militar, además de la financiación, el entrenamiento y el equipamiento o la prestación de apoyo operacional a ese grupo". ${ }^{6}$

Puesto que la ley especial o derecho aplicable a este contexto es el DIH, como veremos más adelante, nos vamos a concentrar en su objeto, fin y principios, en cuanto a partir de ello nos podemos acercar de una manera metódica. Si bien nos vamos a concentrar en el conflicto armado no internacional, resulta importante hacer referencia al conflicto armado internacional con relación a la interceptación de

Dyilo. Decision on the confirmation of charges (ICC-01/04-01/06-803-tEN) del 29 de enero de 2007, párr. 233.

5 Cfr., cPI, Situación de la República Democrática del Congo. Sala de Primera Instancia I, Prosecutor v. Thomas Lubanga Dyilo. Judgment pursuant to Article 74 of the Statute (ICC-01/04-01/06) de 14 de marzo de 2012, párr. 541.

6 Ibíd., párr. 541. (Traducción libre) Dice textualmente: "has a role in organising, coordinating or planning the military actions of the military group, in addition to financing, training and equipping or providing operational support to that group", citando a: CPI, Situación de la República Centroafricana, Sala de Cuestiones Preliminares II, Caso Prosecutor v. Jean-Pierre Bemba Gombo. Decision Pursuant to Article 61(7)(a) and (b) of the Rome Statute on the Charges of the Prosecutor Against Jean-Pierre Bemba Gombo. (ICC-01/05-01/08-424) de 15 de junio de 2009, párr. 137. 
comunicaciones, porque es el que ha tenido mayor desarrollo normativo.

\subsection{Fin, objeto y principios rectores del DIH y sus efectos en las injerencias de comunicaciones} El objetivo del DIH es "preservar la dignidad del ser humano en el marco de los conflictos armados", garantizando un mínimo de humanidad de tal manera que sus efectos resulten ser estrictamente necesarios. Siendo así, tiene por objeto la existencia de la persona, como lo dice Swinarski:

Buscando 'el bien protegido' en ultima ratio legis por el Derecho Internacional Humanitario habrá de concluir que es ello la 'humanidad', percibida no tanto como un sentimiento o una actitud de un ser humano ante las vicisitudes del destino de otro, sino, sobre todo, como un conjunto de seres humanos que tienen que seguir existiendo, superando los peligros de la guerra. ${ }^{8}$

Su normatividad tiene por fin llegar a "un equilibrio entre las necesidades militares y el principio de humanidad", buscando garantizar la existencia de las personas en conflicto

7 Salmón, Elizabeth. Introducción al derecho internacional humanitario. Fondo Editorial de la Pontificia Universidad Católica de Lima-Comité Internacional de la Cruz Roja. Lima, 2004, p. 19.

8 Swinarski, Christophe. Principales nociones e institutos del derecho internacional bumanitario como sistema de protección de la persona. 2. ${ }^{a}$ ed., Instituto Interamericano de Derechos Humanos. San José, 1991, p. 20.

9 Ibíd., p. 25. 
armado, en el entendido de que una "guerra, ya sea internacional o doméstica, significa destrucción" ${ }^{10}$ Esta rama del derecho termina siendo lex specialis en el marco de conflictos armados, y por su carácter de garantizar la humanidad, es considerada por la comunidad internacional como normatividad imperativa, acorde a los artículos 53 y 60.5 de la Convención de Viena sobre el Derecho de los Tratados 1969: el art. 53 ordena que un tratado que vaya en contra de una norma imperativa del derecho internacional, conocido como Ius Cogens, será nulo al momento de su celebración, y define que dicha norma imperativa es aceptada y reconocida por toda la comunidad internacional; el art. 60 referente a la terminación de un tratado o la suspensión de este, en su numeral 5 plantea que no se podrá aplicar en aquellas disposiciones de protección de la persona humana en tratados de carácter humanitario. ${ }^{11}$

10 Thürer, Daniel. International Humanitarian Law: Theory, Practice, Context. Hague Academy of International Law. Haya, 2011, p. 82.

11 Cfr., Chetail, Vincent. The contribution of the International Court of Justice to international bumanitarian law. International Review Red Cross. Junio-2003, Vol. 85 n. ${ }^{\circ}$ 850, pp. 247, 259; y Corte Constitucional, Sentencia C-291 de 2007. Sin embargo, otra postura de la doctrina considera que no todas la normas del DIH constituyen normas de Ius Cogens:

para la Corte Internacional de Justicia el Derecho Internacional Humanitario es una norma consuetudinaria, tal y como la sostiene la Corte en los fallos mencionados. Pero lo anterior no quiere decir que nos encontremos frente a normas imperativas o ius cogens; por ende, no podemos compartir una tesis como la de la Corte Constitucional de Colombia, que identifica los conceptos de costumbre, normas de ius cogens y Derecho Internacional Humanitario.

Abello Galvis, Ricardo. Introducción al estudio de las normas de ius cogens en el seno de la comisión de derecho internacional, CDI. En: Vniversitas, 
Considerando su fin, el objeto es precisamente el contexto de conflicto armado. Como nos vamos a concentrar en el conflicto armado no internacional, su principal normatividad está regulada dentro del art. $3 .^{\circ}$ común a los Convenios de Ginebra, y el Protocolo Adicional II a los mismos, y encontramos que estos se activan cuando se presentan elementos objetivos, en el caso del art. 3. ${ }^{\circ}$ común, al decir que " $[\mathrm{e}] \mathrm{n}$ caso de conflicto armado que no sea de índole internacional y que surja en el territorio de una de las Altas Partes Contratantes". ${ }^{12}$ Así, vemos que la existencia del conflicto no está condicionado a una declaración por parte de un Estado parte; solamente se requiere que se cumplan los elementos propios de la definición de conflicto armado no internacional, como se expuso anteriormente, y que este se encuentre dentro del territorio de un Estado parte. ${ }^{13}$

Pontificia Universidad Javeriana-Facultad de Ciencias Jurídicas (n. ${ }^{\circ}$ 123) ISSN: 0041-9060. Bogotá (julio-diciembre) 2011, p. 99.

12 Conferencia Diplomática para Elaborar Convenios Internacionales destinados a proteger las víctimas de la Guerra. Artículo 3 común a los cuatro Convenios de Ginebra. Tomado de III Convenio de Ginebra del 12 de agosto de 1949 relativo al trato debido a los prisioneros de guerra. Aprobado el $12 \mathrm{de}$ agosto de 1949.

13 Cfr., CidH, Caso de la Masacre de Mapiripán v. Colombia. Sentencia 15 de septiembre de 2005, párrs. 107-115; Cfr., Corte Constitucional, sentencias C-225 de 1995 y C-574 de 1992; Corte Suprema de Justicia-Sala de Casación Penal, Rad. 35.099, Sentencia de 23 de marzo de 2011. También es importante señalar que el Protocolo II en el art. 1.1, además de los criterios comunes al art. 3 común, exige para su aplicación que "ejerzan sobre una parte de dicho territorio un control tal que les permita realizar operaciones militares sostenidas y concertadas y aplicar el presente Protocolo"; Conferencia Diplomática sobre la Reafirmación y el Desarrollo del Derecho Humanitario Aplicable en los Conflictos Armados. Protocolo II adicional a los Convenios de Ginebra de 
Dentro de los tratados y costumbres que definen al DIH, es posible configurar una serie de principios rectores:

Los Convenios internacionales son una multitud de reglas que enuncian, en términos precisos, las obligaciones de los Estados. Pero, por encima de estas disposiciones particulares, hay cierto número de principios en los que se inspira el conjunto de la materia. A veces, están expresamente formulados en los Convenios; a veces, sería inútil buscar su enunciación, porque figuran implícitamente y expresan la sustancia del tema. A veces, incluso se derivan de la costumbre. ${ }^{14}$

Estos principios, también imperativos, sirven para desarrollar una interpretación correcta al momento de aplicar en concreto el DIH, asegurando que sea acorde al fin último. Hay que tener en cuenta que de un principio se derivan otros principios, encadenándose en ellos. Siendo así, entramos a exponer los principales:

- Principio de Humanidad Partimos del principio de humanidad, cuyo contenido no solamente busca garantizar la existencia de las

1949 relativo a la protección de las víctimas de los conflictos armados sin carácter internacional. Aprobado el 8 de junio de 1977.

14 Pictet, Jean. Desarrollo y principios del derecho internacional bumanitario. Curso dado el mes de julio de 1982 en la Universidad de Estrasburgo en el marco de la Reunión de Enseñanza organizada por el Instituto Internacional de Derechos Humanos. Instituto Henry Dunant, Comité Internacional de la Cruz Roja. 3. ${ }^{a}$, reimpresión, Gráficas Ducal Ltda. San José, 2001, p. 71. 
personas en el conflicto, sino que además consiste en "respetar y tratar a todas las personas con humanidad, tanto a los combatientes, como a los no combatientes, quienes en todo momento deberán ser tratados con humanidad". 15

- Principio de necesidad militar

En contraste con el principio de humanidad, está el principio de necesidad militar; este "justifica aquellas medidas de violencia militar que son necesarias y proporcionadas para garantizar el rápido sometimiento del enemigo con el menor costo posible en vidas humanas y recursos económicos". ${ }^{16}$ La necesidad militar parte "[d]el derecho a emplear la violencia, en la forma y el grado necesarios para obligar al adversario a someterse cuanto antes con el menor costo posible en dinero y vidas humanas". ${ }^{17}$ De manera que cada conducta que realice uno de los miembros sujetos del conflicto no puede ser arbitraria, sino que debe corresponder a una necesidad justificada en las exigencias del conflicto, donde dicha justificación

15 Salmón Elizabeth. Op. cit., p. 56.

16 Ibíd., p. 58.

17 Hernández Hoyos, Diana. Op. cit., p. 252, citando a: Pictet, Jean. Comentarios del Protocolo I del 8 de junio de 1977 adicional a los convenios de ginebra del 12 de agosto de 1949. Trad. de Mauricio Duque Ortiz. Comité Internacional de la Cruz Roja. Plaza \& Janés Editores Colombia S.A., Bogotá, 2001, p. 555. 
se construye a partir de la proporcionalidad entre la necesidad y la humanidad. ${ }^{18}$

- Principio de limitación

En relación con la conducción de hostilidades, el principio de limitación consiste precisamente en limitar aquellos medios y métodos que sean utilizados en un ataque. "Este principio rechaza el recurso a la necesidad militar para justificar un interés militar absoluto, limitando la libertad de los beligerantes en la elección de los medios y métodos de combate en sus operaciones". ${ }^{19}$ A su vez, se deriva el principio de la prohibición de causar daños superfluos o sufrimientos innecesarios, dado que "debe haber un equilibrio entre el daño causado, el sufrimiento infligido al enemigo y la eficacia militar" ${ }^{20}$

- Principio de distinción

Desde esta base, resulta necesario diferenciar los sujetos activos del conflicto. Ante esto nace el principio de distinción, que consiste en la obligación de distinguir entre los objetivos militares y quienes participan directamente en las hostilidades, y aquellas personas y/o bienes protegidos, y se prohíbe desarrollar ataques indiscriminados en donde no resulta posible

18 Cfr., Thürer, Daniel. Op. cit., pp. 68, 75.

19 Ibíd., p. 59.

20 Ibíd., p. 59. 
hacer esta diferenciación. ${ }^{21}$ Por tanto, es necesario entender el concepto de objetivo militar, según el cual "solo se podrán atacar bienes que por su naturaleza, ubicación, finalidad, o utilización contribuya eficazmente a la acción militar y cuya destrucción total o parcial, captura o neutralización ofrezcan una ventaja militar". ${ }^{22}$ Asimismo, hay que saber quiénes participan directamente en las hostilidades, considerando que hay una prohibición expresa de cometer daño a quienes no participen directamente de estas. Dentro de la normatividad del conflicto armado no internacional, resulta necesario resaltar lo siguiente del numeral primero del art. 3 común de los cuatro tratados de Ginebra:

1) Las personas que no participen directamente en las hostilidades, incluidos los miembros de las fuerzas armadas que hayan depuesto las armas y las personas puestas fuera de combate por enfermedad, herida, detención o por cualquier otra causa, serán, en todas las circunstancias, tratadas con humanidad, sin distinción alguna de índole desfavorable basada en la raza, el color, la religión o la

21 Cfr., Hernández Hoyos, Diana. Derecho internacional bumanitario. 3. ${ }^{2}$ ed., Ediciones Nueva Jurídica. Bogotá, 2012, p. 253; Salmón Elizabeth. Op. cit., p. 59; y Thürer, Daniel. Op. cit., p. 87. Dice este último: "El objetivo principal del principio de distinción es la protección de no combatientes" (traducción libre).

22 Salmón Elizabeth. Op. cit., p. 56. 
creencia, el sexo, el nacimiento o la fortuna o cualquier otro criterio análogo (cursivas fuera del texto).

- Principio de proporcionalidad Seguidamente, el asunto de en qué o quién se comete un ataque militar debe estar regido por el principio de proporcionalidad, ordenando una relación de equilibrio entre el daño colateral producido y la ventaja militar que se obtiene, ${ }^{23}$ "exig[iendo] que el efecto entre los medios y métodos de combate escogidos y utilizados no sean desproporcionados con la ventaja militar que se busca obtener" ${ }^{24}$

Todos los principios se tienen en cuenta al momento de analizar la proporcionalidad de un ataque o una actuación militar. El profesor Daniel Thürer plantea que el principio de proporcionalidad se podría desarrollar en tres niveles: el primer nivel consiste en analizar la acción militar de que se esté tratando, que "deba ser adecuada para lograr el objetivo que representa la necesidad militar"; 25 el segundo nivel observa la proporcionalidad de los medios y métodos del combate, que no produzcan daños excesivos en proporción a la ventaja miliar que se obtenga; y el tercer nivel consiste en estudiar la relación entre la necesidad militar y el principio de humanidad, estu-

23 Hernández Hoyos, Diana. Op. cit., p. 253.

24 Salmón Elizabeth. Op. cit., p. 58.

25 Thürer, Daniel. Op. cit., p. 76. 
diando los intereses que envuelve el ataque. ${ }^{26}$ En otras palabras, el primer nivel estudia la relación del ataque con la necesidad militar; el segundo trata el ataque de manera cuantitativa con respecto a la ventaja militar; y el tercero lo estudia de manera cualitativa a partir del principio de humanidad.

De igual forma, estos principios son utilizados en los conflictos armados, sin distinguir el tipo. La decisión del caso Tadic ya citada considera que "la esencia general de esas reglas [refiriéndose al DIH], y no la regulación detallada que pueda contener, es aplicable a los conflictos internos" ${ }^{27}$ Sin embargo, a pesar de que la esencia general en su conjunto es aplicable a los conflictos en general, encontramos que su regulación para algunas actuaciones depende de qué tipo de conflictos armados estemos discutiendo, dado que hay algunas particularidades que no se regulan en el conflicto armado no internacional, por tanto también resulta necesario estudiarlo a la luz del DIDH. ${ }^{28}$

El art. 24 en el Reglamento concerniente a las Leyes o Costumbres de la Guerra Terrestre (RGT) de 1907 dice: "Los

26 Cfr., Ídem.

27 TPIY, Prosecutor v. Tadic, Dusko. Decision on the defence motion for interlocutory appeal on jurisdiction (IT-94-1-A) de 2 de octubre de 1995. (Traducción libre) Dice textualmente: "the general essence of those rules, and not the detailed regulation they may contain, has become applicable to internal conflicts"; Cfr., Moir, Lindsay. The Law of Internal Armed Conflict. University of Cambridge. Cambridge, 2002, pp. 188-192.

28 Moir, Lindsay. Op. cit., pp. 193-231. 
ardides de la guerra y el empleo de las medidas necesarias para la obtención de información sobre el enemigo y el país se considerarán permisibles". ${ }^{29}$ Este artículo enfocado al conflicto armado internacional tiene por regla general que los medios para obtener información del enemigo sean lícitos, siempre y cuando versen sobre el enemigo.

En la regulación sobre conflictos armados no internacionales no encontramos una prohibición expresa de esta conducta. Quedarse con la posición de Tadic, si bien es cierto que ha dado un gran aporte para la regulación de conflictos internos en diferentes materias, ${ }^{30}$ también tiene que ser analizado a la luz de DIDH, en cuenta los dos terminan siendo aplicables conjuntamente, como entramos a ver. Adicionalmente, es importante resaltar que Jean Pictet estableció tres principios comunes entre el DIH y el DIDH:

1. Principio de inviolabilidad, según el cual "el individuo tiene derecho al respeto de su vida, de su integridad física y moral y de los atributos inseparables de la personalidad"; $; 1$

2. Principio de no discriminación, que Elizabeth Salmón ha entendido como el imperativo de que "todos

29 Segunda Conferencia de Paz de la Haya. Reglamento concerniente a las leyes y costumbres de la guerra terrestre. Anexo al Convenio IV relativo a las leyes y costumbres de la guerra. Adoptada el 18 de octubre de 1907. (Traducción libre) Dice textualmente: "Uses of war and the employment of measures necessary for obtaining information about the enemy and the country are considered permissible".

\footnotetext{
30 Cfr., Moir, Lindsay. Op. cit., p. 133.

31 Pictet, Jean. Op. cit., p. 75.
} 
deberán ser tratados sin distinción desfavorable de ningún tipo; $;^{32} \mathrm{y}$

3. Principio de seguridad, que consiste en la seguridad de la persona, relacionándolo directamente con las garantías judiciales y los derechos que reconocen los convenios como irrenunciables. ${ }^{33}$

Sobre este último, en el caso de los conflictos armados no internacionales, encontramos la protección de garantías judiciales en el art. 3 común, Inc. 2, lit. d:

En caso de conflicto armado que no sea de índole internacional y que surja en el territorio de una de las Altas Partes Contratantes, cada una de las Partes en conflicto tendrá la obligación de aplicar, como mínimo, las siguientes disposiciones:

1) Las personas que no participen directamente en las hostilidades, incluidos los miembros de las fuerzas armadas que hayan depuesto las armas y las personas puestas fuera de combate por enfermedad, herida, detención o por cualquier otra causa, serán, en todas las circunstancias, tratadas con humanidad, sin distinción alguna de índole desfavorable basada en la raza, el color, la religión o la creencia, el sexo, el nacimiento o la fortuna o cualquier otro criterio análogo.

32 Salmón Elizabeth. Op. cit., p. 74; Cfr., Pictet, Jean. Op. cit., p. 79.

33 Cfr., Pictet, Jean. Op. cit., pp. 80, 81. 
A este respecto, se probiben, en cualquier tiempo y lugar, por lo que atañe a las personas arriba mencionadas: [...]

d) las condenas dictadas y las ejecuciones sin previo juicio ante un tribunal legítimamente constituido, con garantías judiciales reconocidas como indispensables por los pueblos civilizados (cursivas fuera del texto).

\subsection{Las interceptaciones de comunicaciones a la luz del DIDH}

\subsubsection{La relación entre el DIH y el DIDH}

Cuando una conducta no está prohibida expresamente por el DIH, como es el caso de las injerencias de las comunicaciones privadas, pero que a la luz del DIDH pareciera vulnerar un derecho consagrado, como el derecho a la intimidad, se hace necesario un estudio de este derecho en contexto. ${ }^{34}$

Esto nos acerca a otro punto en común que son aquellos derechos humanos que no admiten suspensión o derogación temporal en casos especiales como el contexto del conflicto armado, regulado en el Pacto Internacional de los Derechos Civiles y Políticos (PIDCP), en el art. 4.2. ${ }^{35}$

34 Naciones Unidas, Consejo Económico y Social-Comisión de Derechos Humanos. Informe de la Subcomisión de prevención de discriminaciones y protección a las minorías sobre su $46^{\circ}$ periodo de sesiones-Declaración de Normas Humanitarias Minimas (Normas de Turku). E/CN.4/1995/116 de 31 de enero de 1995; Cfr., Thürer, Daniel. Op. cit., pp. 132-137.

35 "La disposición precedente no autoriza suspensión alguna de los artículos 6, 7, 8 (párrafos 1 y 2), 11, 15, 16 y 18”. A pesar de que los artículos no dicen qué derecho es, como sí sucede con los instrumentos regionales de 
Encontramos que las personas que no participan directamente en las hostilidades, incluyendo a los miembros de las fuerzas armadas que hayan sido detenidos, tendrán derecho a un juicio con respeto a las garantías judiciales. En el PIDCP, el Comité de Derechos Humanos, en su Observación General n. ${ }^{\circ} 29$, no se podrán suspender los derechos que se encuentran enlistados en el art. 4. 2. que son: el derecho a la vida, la prohibición de la tortura o trato cruel, inhumano o degradante, la prohibición de la esclavitud, trata de esclavos o servidumbre, encarcelamiento por incumplimiento contractual, al cumplimiento del principio de legalidad en materia penal, reconocimiento a la personalidad jurídica, y la libertad de pensamiento, conciencia y religión.

El art. 14 del Pacto que regula las garantías judiciales, si bien no está dentro del listado de derechos que no admiten suspensión, el Comité de Derechos Humanos, siendo el órgano encargado de interpretar el pacto a partir de sus observaciones generales, consideró que la relación entre este y los art. 6 y 15, obligan a que a que las garantías judiciales tampoco se pueda suspender. ${ }^{36}$

derechos humanos, entendemos el siguiente orden, respectivamente: derecho a la vida, prohibición de torturas, prohibición a la esclavitud y servidumbre, no pena por incumplimiento contractual, principio de legalidad, reconocimiento de la personalidad jurídica y derecho a la libertad religiosa, de conciencia, de pensamiento, de expresión.

36 Naciones Unidas, Comité de Derechos Humanos. Observación General n. ${ }^{\circ} 29$, artículo 4 (Estados de emergencia) CCPR/C/21/Rev.1/Add.11 del 31, agosto de 2001, párrs. 15, 16:

15. Es inherente a la protección de los derechos expresamente reconocidos como no susceptibles de suspensión en el párrafo 2 del artículo 4 , 
$\mathrm{Al}$ revisar el art. 14, si bien no tiene una regulación propia de una regla exclusión, sí hay algunos puntos que se pueden relacionar con esta, por ejemplo el num. 2: "[t]oda persona acusada de un delito tiene derecho a que se presuma su inocencia mientras no se pruebe su culpabilidad conforme a la ley", o el num. 3. g., "[a] no ser obligada a declarar contra sí misma ni a confesarse culpable”. Sobre este punto, vemos que el proceso tiene que estar sujeto al proceso que defina la Ley, y además condiciona la licitud de una confesión.

que han de ser garantizados mediante garantías procesales, generalmente de carácter judicial. Las disposiciones del Pacto que se refieran a las garantías procesales nunca podrán ser el objeto de medidas que de alguna forma socaven la protección de los derechos que no son susceptibles de suspensión; la revocación o utilización del artículo 4 nunca podrá realizarse de forma que produzca la suspensión de alguno de los derechos cuya suspensión no está autorizada. Más aún, al ser imposible la suspensión de la totalidad de las disposiciones del artículo 6 del Pacto, cualquier imposición de la pena de muerte durante un estado de emergencia no debe contradecir las disposiciones de Pacto y, consecuentemente, ha de cumplir inter alia con todos los requisitos de los artículos 14 y 15.

“16. Las garantías relacionadas con la institución de la suspensión, según se definen en el artículo 4 del Pacto, se basan en los principios de legalidad y del Estado de derecho inherentes al Pacto en su conjunto. Como ciertos elementos del derecho a un juicio imparcial están explícitamente garantizados por el derecho humanitario internacional en tiempo de conflicto armado, el Comité no encuentra ninguna justificación para suspender dichas garantías durante cualquier otra situación de excepción. A juicio del Comité, dichos principios y la disposición sobre recursos efectivos exigen que los principios fundamentales del derecho a un juicio imparcial se respeten durante un estado de excepción. Sólo un tribunal de derecho puede enjuiciar y condenar a una persona por un delito, y se debe respetar la presunción de inocencia. Con el objeto de proteger los derechos que no pueden ser objeto de suspensión, se sigue de este mismo principio que el derecho de acceso a los tribunales, para que éstos decidan sin demora obre la legalidad de cualquier clase de detención, no debe ser afectado por la decisión del Estado Parte de suspender ciertas garantías del Pacto. 
Adicionalmente, es importante resaltar que el Comité de Derechos Humanos prohíbe la admisibilidad y utilización de pruebas en los procesos judiciales que se hayan producido por medio de torturas o tratos prohibidos, como un desarrollo del art. 7 del Pacto. ${ }^{37}$

Ante este punto encontramos que el Sistema Interamericano de Derechos Humanos, el art. 27.2. de la CADH sí menciona expresamente la protección de las garantías judiciales. ${ }^{38}$

La CIDH ha entendido el concepto de "garantía" de que trata en el art. 27.2, de la siguiente forma:

Las garantías [judiciales] sirven para proteger, asegurar o hacer valer la titularidad o el ejercicio de un derecho. Como los Estados Partes tienen la obligación de reconocer y respetar los derechos y libertades de la persona,

37 Naciones Unidas, Recopilación de las observaciones generales y recomendaciones generales adoptadas por órganos creados en virtud de tratados de derechos humanos (HRI/GEN/1/Rev.9 (Vol. I)) de 27 de mayo de 2008, p. 241, párr. 12. Haciendo referencia a la Observación General n. ${ }^{\circ} 20$, Prohibición de la tortura u otros tratos o penas crueles, inhumanos o degradantes (art. 7).

38 Conferencia Interamericana de Derechos Humanos. Convención Americana de Derechos Humanos. Adoptada el 22 de noviembre de 1969. Entrada en vigor el 18 de julio de 1978.

Artículo 27. Suspensión de Garantías [...] 2. La disposición precedente no autoriza la suspensión de los derechos determinados en los siguientes artículos: 3 (Derecho al Reconocimiento de la Personalidad Jurídica); 4 (Derecho a la Vida); 5 (Derecho a la Integridad Personal); 6 (Prohibición de la Esclavitud y Servidumbre); 9 (Principio de Legalidad y de Retroactividad); 12 (Libertad de Conciencia y de Religión); 17 (Protección a la Familia); 18 (Derecho al Nombre); 19 (Derechos del Niño); 20 (Derecho a la Nacionalidad), y 23 (Derechos Políticos), ni de las garantías judiciales indispensables para la protección de tales derechos. 
también tienen la de proteger y asegurar su ejercicio a través de las respectivas garantías (art. 1.1), vale decir, de los medios idóneos para que los derechos y libertades sean efectivos en toda circunstancia.

$[\ldots]$

El artículo 27.2 no vincula esas garantías judiciales a ninguna disposición individualizada de la Convención, lo que indica que lo fundamental es que dichos procedimientos judiciales sean indispensables para garantizar esos derechos. ${ }^{39}$

A partir de esto, una "garantía judicial” se entiende como aquel mecanismo judicial sencillo y rápido que sirve para la protección de los derechos consagrados en la Constitución, las leyes o en la Convención Americana acorde al art. 25.1. ${ }^{40}$ Pero en los casos en que haya una suspensión de derechos, regulado por el art. 27.1, las garantías judiciales tendrán que velar por la protección de los derechos consagrados en el art. 27.2, y con los demás derechos que sí son sujetos de suspensión se tendrá que estudiar la justificación entre la medida que se adoptó y el derecho que se haya vulnerado. ${ }^{41}$ No sobra decir que cuando se dice "judicial”, se entiende que se cuenta con un órgano judicial "independiente e imparcial, apto para determinar la legalidad de las actuaciones que se cumplan

$39 \mathrm{CIDH}$, Opinión Consultiva. El hábeas corpus bajo Suspensión de Garantías, OC-8/87, de 30 de enero de 1987, párrs. 20, 24-27, 42, párrs. 25, 27.

40 Cfr., Ibíd., 32; y CIDH, Opinión Consultiva, Garantías judiciales en estados de emergencia, OC-9/87 de 6 de octubre de 1987, párrs. 22, 23.

41 Cfr., Ibíd., párrs. 20-25. 
dentro del estado de excepción" ${ }^{42}$ Con relación al art. $8^{\circ}$ de la Convención, se debe tener en cuenta que este propiamente no trata de un recurso judicial propiamente dicho, sino de unos requisitos que se deben tener en los procesos judiciales para que puedan ser consideradas propiamente como parte del debido proceso. ${ }^{43}$ Siendo así, podemos inferir que el debido proceso es en sí mismo una garantía que no puede ser suspendida en los estados de excepción. ${ }^{44}$ Bajo este entendido, la Corte ha señalado que el habeas corpus y la acción de amparo han sido consideradas como garantías judiciales en cuanto sirven "para impedir su desaparición o la indeterminación de su lugar de detención, así como para protegerla contra la tortura u otros tratos o penas crueles, inhumanos o degradantes", ${ }^{45}$ y por tanto se considera este mecanismo como una garantía judicial, reafirmando que no es susceptible de suspensión. ${ }^{46}$

Con respecto a la regla de exclusión, "la Corte ha sostenido que la anulación de los actos procesales derivados de la tortura o tratos crueles constituye una medida efectiva para hacer cesar las consecuencias de una violación a las

42 Ibíd., párr. 30.

43 Cfr., CIDH, Garantías judiciales en estados de emergencia, OC-9/87 de 6 de octubre de 1987, párr. 27.

44 Cfr., Ibíd., párr. 30.

$45 \mathrm{CIDH}$, Opinión Consultiva El hábeas corpus bajo suspensión de garantías. OC-8/87 de 30 de enero de 1987, párrs. 35, 42.

46 Cfr., Ibíd., párrs. 32, 35, 42; y CIDH, Opinión Consultiva. El hábeas corpus bajo suspensión de garantias, OC-8/87 de 30 de enero de 1987, párrs. 31-33. 
garantías judiciales", ${ }^{47}$ entendiendo que precisamente la regla de exclusión consiste en la nulidad de la prueba y por tanto la consecuencia de que el juez no la valore, en regla con art. 8.3 de la Convención. En el caso Cabrera García $y$ Montiel Flores c. México, en los hechos encontramos que las víctimas fueron sometidas a tratos crueles e inhumanos, por lo cual las dos víctimas confiesan los delitos por los que se les procesa penalmente; ante esto la Corte considera que hubo una violación del art. 8.3 de la Convención. ${ }^{48}$ Cabe señalar que dentro del instrumento internacional, si bien el art. 8 en su conjunto señala los elementos del debido proceso, solamente regula en el art. 8.3 los casos exclusión de confesiones por cualquier coacción, en concordancia con el derecho de no ser obligado a autoincriminarse, según el art. 8.2.g. ${ }^{49}$ Sin embargo, la Corte no se pronuncia sobre si se debió excluir o no la prueba, y qué efectos produciría; solamente se enfoca en si hubo o no violación de derecho, como en el caso que mencionamos en el art. 8.3 de la CADH. ${ }^{50}$ Así las cosas, el DIH y DIDH no se excluyen dentro de un marco del contexto del conflicto armado, sino que se

47 CidH, Caso Cabrera García y Montiel Flores v. México, Sentencia de 26 de noviembre de 2010, párr. 166.

48 Cfr., Ibíd., párrs. 167, 175-177.

49 Cfr., CidH, Caso Bayarri v. Argentina. Sentencia de 30 de Octubre de 2008, párr. 108; y CidH, Caso Cantoral Benavides v. Perú. Sentencia de 18 de agosto de 2000, párrs. 131-133. Concordante con el art. 14.3 de PIDCP.

50 Cfr., cidh, Caso Castillo Petruzzi y otros v. Perú. Sentencia de 30 de mayo de 1999, párrs. 142, 149, 156; CIDH, Caso Cantoral Benavides v. Perú. Sentencia de 18 de agosto de 2000, párr. 128; y CidH, Caso Lori Berenson Mejía v. Perú. Sentencia de 25 de noviembre de 2004, párrs. 181, 189. 
complementan el uno al otro. Tanto el art. 3 común a los Convenios de Ginebra, así como el pIDCP y el desarrollado el Sistema Interamericano establecen que en cualquier caso siempre se deberán proteger las garantías judiciales.

\subsubsection{Análisis de las injerencias de comunicaciones}

\section{a la luz DIDH}

En este caso en el sistema universal de derechos humanos encontramos el art. 17 del Pacto que reza:

Artículo 17.

1. Nadie será objeto de injerencias arbitrarias o ilegales en su vida privada, su familia, su domicilio o su correspondencia, ni de ataques ilegales a su honra y reputación.

2. Toda persona tiene derecho a la protección de la ley contra esas injerencias o esos ataques. ${ }^{51}$

Adicionalmente, encontramos el Comentario General n. ${ }^{\circ} 16$, artículo 17 (referente al derecho a la intimidad), en el cual no se aprecia un mayor desarrollo en cuanto a las injerencias de comunicaciones. Encontramos que a pesar de que la regla general en un estado de normalidad es que la interceptación de comunicaciones solo es admisible por autorización judicial, y si otros sujetos fuera de los autorizados la desarrollan estarían delinquiendo; si esta viola el

51 Naciones Unidas. Asamblea General. Pacto Internacional de Derechos Civiles y Políticos. Adoptada en su Resolución 2200 A (XXI) de 16 de diciembre de 1966. 
derecho a la defensa, será excluida del expediente. Sin embargo, cuando se entra en una situación de emergencia, o cuando se requiere una actuación urgente, puede tener un tratamiento diferente. ${ }^{52}$

\subsubsection{Desarrollo de injerencias de comunicaciones en el Sistema Interamericano de Derechos Humanos}

La convención prohíbe injerencias arbitrarias, según el art. 11 de la Convención. ${ }^{53}$ Ante esto la Corte ha dicho que "la

52 Naciones Unidas, Asamblea General. Informe del Comité de Derechos Humanos, cuadragésimo tercer periodo de sesiones suplemento n. ${ }^{\circ} 40$ (A/43/40) de 28 de septiembre de 1988. Encontramos que el estado de Trinidad y Tobago considera que "[d] urante un estado de emergencia, la injerencia en la vida privada no era arbitraria si se llevaba a cabo de conformidad con las disposiciones de la Constitución” (párr. 70); el Estado de Dinamarca considera que se requiere orden judicial para adelantar escuchas telefónicas "excepto cuando fuera necesaria una acción urgente; en tales casos era preciso conseguir la autorización retroactiva del tribunal dentro de las 24 horas siguientes a la instalación del aparato" (párr. 179); la República de Ecuador admite que "en caso de guerra, disturbios internos o situación de emergencia, el comandante de las fuerzas armadas asumiría el control de las telecomunicaciones" (párr. 342); Francia explica que los particulares no podían hacer escuchas telefónicas so pena de prisión, y asegura que las interceptaciones de comunicaciones solo se pueden hacer por una orden del juez de instrucción, y en el caso de que el Tribunal de Casación encuentre que esta viola el derecho a la defensa, la podrá retirar del expediente, es decir, la podrá excluir (párr. 396); y Australia, donde considera que la Fiscalía, en los casos de seguridad nacional, y la Corte Suprema de Justicia, en los casos relacionados con estupefacientes, son las autoridades competentes para adelantar las escuchas telefónicas; un agente comercial o de investigación que adelante dichas interceptaciones será considerado infractor de un delito (párr. 446).

53 CADH. Supra. n. 192.

Artículo 11. Protección de la Honra y de la Dignidad.

[...]

2. Nadie puede ser objeto de injerencias arbitrarias o abusivas en su 
protección a la vida privada se concreta en el derecho a que sujetos distintos de los interlocutores no conozcan ilícitamente el contenido de las conversaciones telefónicas o de otros aspectos, [...] propios del proceso de comunicación" ${ }^{54}$ Sin embargo, este derecho no es absoluto, y por tanto puede ser restringido siempre y cuando la injerencia "cumpl[a] con los siguientes requisitos: a) estar prevista en ley; b) perseguir un fin legítimo, y c) ser idónea, necesaria y proporcional. En consecuencia, la falta de alguno de dichos requisitos implica que la injerencia es contraria a la Convención". ${ }^{55}$

Concentrándonos en las injerencias propiamente dichas por parte del Estado, en el caso Escher y otros v. Brasil, los hechos se dieron tras una reforma agraria que hizo que las organizaciones sociales de Associação Comunitária de Trabalhadores Rurais (ADECON) y Cooperativa Agrícola de Conciliação Avante Ltda. (COANA) y sus líderes, entre ellos Arlei José Escher, adelantaran algunas protestas, a quienes les fueron interceptadas y grabadas comunicaciones privadas por la Policía Militar; a este respecto, se debe tener en cuenta que únicamente es competente la policía civil cuando

vida privada, en la de su familia, en su domicilio o en su correspondencia, ni de ataques ilegales a su honra o reputación.

3. Toda persona tiene derecho a la protección de la ley contra esas injerencias o esos ataques.

54 CIDH, Caso Escher y otros v. Brasil. Sentencia de 6 de julio de 2009, párr. 114; Cfr., Cidh, Caso Tristán Donoso v. Panamá. Sentencia de 27 de enero de 2009, párr. 55.

55 CidH, Caso Escher y otros v. Brasil. Sentencia de 6 de julio de 2009, Párr. 129; Cfr., CiDH, Caso Tristán Donoso v. Panamá. Sentencia de 27 de enero de 2009, párr. 56. 
no conste la existencia de investigación criminal. Según la legislación interna, la decisión para que se adelanten estas interceptaciones tiene que ser fundamentada, pero no se mostró cuáles eran los indicios de autoría o participación de delitos que pudiesen haber cometido, ni cuál sería el método para hacer la interceptación, pero aun así se concedió la autorización judicial para que se gestionaran dichas injerencias. Tampoco se aporta la autorización judicial por la cual se prorroga la interceptación, como tampoco se notificó al Ministerio Público, ni las interceptaciones fueron transcritas, como ordena la ley interna. ${ }^{56}$ También hubo violación del mismo artículo en cuanto que hubo divulgación de las interceptaciones en los medios de comunicación, cuando estas se encontraban bajo secreto judicial. ${ }^{57}$ Se estudia el caso a la luz de los arts. 8.1 y 25 de la Convención, en cuanto que el Estado no adelantó investigaciones contra quienes divulgaron la información y sobre la no justificación por haber concedido la interceptación. ${ }^{58}$ Por tales razones, la Corte Interamericana considera que hubo una violación de los arts. 11.1, 11.2, 8.1, y 25 de la Convención; sin embargo, en este caso no se estudió la exclusión probatoria porque no se adelantó un proceso judicial propiamente ante un juez de conocimiento.

56 Cfr., CidH, Caso Escher y otros v. Brasil. Sentencia de 6 de julio de 2009, párrs. 130-146.

57 Cfr., Ibíd., párr. 164.

58 Cfr., Ibíd., párrs. 206, 209. 
El caso de Tristán Donoso v. Panamá consistió en unas grabaciones de las interceptaciones que se le hicieron a Santander Tristán Donoso, quien actuaba como abogado. En este caso, la Corte considera que no hubo vulneración del art. 11.2, dado que no se logró probar que estas fueran imputables a entidades del Estado. ${ }^{59}$ Sin embargo, considera que sí hubo vulneración del derecho a la honra y reputación por el hecho de que las grabaciones fueron conocidas por los medios de comunicación, sin que se tuviera autorización, y además por los diferentes pronunciamientos de la Procuraduría panameña que incidieron en esos derechos. ${ }^{60}$

Finalmente, es importante resaltar que en ambos casos se hizo un análisis de proporcionalidad, teniendo en cuenta lo regulado por la Ley. ${ }^{61}$ Este análisis se concentró en determinar si las injerencias fueron o no acordes con la legislación interna.

\subsubsection{Desarrollo de la regla de exclusión en el Sistema} Europeo de Derechos Humanos con base en casos de injerencias en las comunicaciones

El derecho a la intimidad está regulado en el art. 8 del Convenio, el cual protege de injerencias arbitrarias las comunicaciones (art. 8.1) y establece que esas injerencias se pueden

59 Cfr., Cidh, Caso Tristán Donoso v. Panamá. Sentencia de 27 de enero de 2009, párrs. 63, 64, 66.

60 Cfr., Ibíd., párr. 76, 83.

61 Cfr., CidH, Caso Escher y otros v. Brasil. Sentencia de 6 de julio de 2009, párrs. 116, 129; y Caso Tristán Donoso v. Panamá. Sentencia de 27 de enero de 2009, párr. 56. 
hacer siempre y cuando sean según la regulación interna (art. 8.2). ${ }^{62}$

El caso Malone v. Reino Unido, consiste en que James Malone había sido investigado y juzgado por diferentes hurtos, pero al no haber evidencia que pudiera demostrar su responsabilidad en juicio resultó absuelto. Sin embargo, durante el proceso judicial se presentaron varias interceptaciones de comunicaciones, tanto de correspondencia como de telefonía, y por tanto Malone interpuso una acción civil contra la Comisaría de Policía Metropolitana por las interceptaciones realizadas; las autoridades respondieron que estas fueron hechas de acuerdo con la ley, lo cual abrió el debate interno sobre una reforma dentro del sistema inglés con respeto a la forma en que se deben adelantar. ${ }^{63}$ Esta Corte, en relación con el art. 8.2, considera que si bien la palabra "ley" abarca tanto la escrita como la no escrita (considerando el sistema de common law), esta debe ser suficientemente clara e indicar las

62 Consejo de Europa. Convenio para la Protección de los Derechos Humanos y de las Libertades Fundamentales (Convenio Europeo de Derechos Humanos). Adoptado el 4 de noviembre de 1950.

Artículo 8. Derecho al respeto a la vida privada y familiar.

1. Toda persona tiene derecho al respeto de su vida privada y familiar, de su domicilio y de su correspondencia.

2. No podrá haber injerencia de la autoridad pública en el ejercicio de este derecho sino en tanto en cuanto esta injerencia esté prevista por la ley y constituya una medida que, en una sociedad democrática, sea necesaria para la seguridad nacional, la seguridad pública, el bienestar económico del país, la defensa del orden y la prevención de las infracciones penales, la protección de la salud o de la moral, o la protección de los derechos y las libertades de los demás.

63 Cfr., Cedh, Caso Malone v. Reino Unido. Sentencia de 2 de agosto 1984, párrs. 12-18, 31-36. 
circunstancias por las cuales las autoridades públicas puedan adelantar interceptaciones de comunicaciones, afirmando que al decir "ley" no es sinónimo a las prácticas administrativas que se han venido estableciendo con el paso del tiempo, y por tanto en ella deberá indicar las competencias con la suficiente claridad de cómo se deben ejercer, para evitar que la medida sea una injerencia arbitraria. ${ }^{64}$ Así las cosas, la Corte encuentra que para el momento de los hechos, la normatividad no tenía suficiente claridad sobre el alcance, ni trata la forma como se deben ejercer las competencias otorgadas a las autoridades públicas, por tanto declara la Corte una violación al art. 8.2 del Convenio Europeo, y niega el alegato del Estado de que estas medidas fueron "necesarias en una sociedad democrática". ${ }^{65}$

El caso Schenck v. Suiza trata del acuerdo entre Pierre Schenck y Richard Pauty para que este último matara a la ex esposa de Schenck, Josette; sin embargo, esto no ocurre y Pauty acuerda con la Policía grabar una conversación entre él y el Schenck, sirviendo como agente provocador para demostrar la instigación para cometer homicidio. ${ }^{66} \mathrm{La}$ grabación fue usada como prueba en el proceso judicial, y llevó a su condena, aun utilizando los diferentes recursos del derecho doméstico. ${ }^{67}$ Al llegar a la CEDH se alegó la violación

\footnotetext{
64 Cfr., ibíd., 66-68.

${ }_{65}$ Cfr., ibíd., párrs. 79, 80, 84, 88.

66 Cfr., CEDH, Caso Schenck v. Suiza. Sentencia de 12 de julio de 1988,
} párrs. 8-13.

67 Cfr., Ibíd., párrs. 25-31. 
de los arts. 6.1, 6.2 y 8.1 (derecho al respeto a la vida privada y familiar); esta consideró que no hubo violación de los derechos consagrados en los art. 6.1 y 6.2 , en cuanto se le dio la oportunidad al procesado para que alegara la autenticidad y contradecir la prueba, adicionando que el análisis conjunto de todo el acervo probatorio conducía a la responsabilidad penal de Schenck. ${ }^{68}$ En relación con el art. 8.1, la Corte no entra a estudiarlo, puesto que no se han agotado los recursos internos. ${ }^{69}$ Sin embargo, esta decisión tiene tres opiniones disidentes, las que consideran que la revisión del art. $6 .^{\circ}$ no debe ser solamente formal y abstracta, y por tanto no se puede basar en pruebas obtenidas de maneras indebidas e ilícitas, por consiguiente concluyen que hubo una violación conjunta de los arts. 6 y 8 de la Convenio Europeo. ${ }^{70,71}$

Esta posición hace eco en diferentes decisiones, llegando a conocerse como "doctrina Schenck". En este caso, se establece la regla de que para que se ordene la exclusión de la prueba primero se debe hacer un análisis conjunto de todas las pruebas; en el caso en que se considere que la prueba que

68 Cfr., Ibíd., párrs. 47-51.

69 Cfr., Ibíd., párr. 53.

70 Cfr., CEDH, Caso Schenck v. Suiza. Opinión disidente conjunta de los jueces Pettiti, Spielmann, De Meyer y Carrillo Salcedo; Opinión disidente conjunta de Pettiti y De Meyer; y Opinión disidente de De Meyer de la Sentencia de 12 de julio de 1988.

71 Hay que tener en cuenta que a la luz del derecho doméstico colombiano, habría que considerar si la grabación por uno de los interlocutores de la conversación es ilícita; según Rojas Gómez, no lo sería porque estaríamos ante una conversación intersubjetiva. Cfr., Rojas Gómez, Miguel Enrique. Op. cit., pp. $50,51,89$. 
se está cuestionando de ilícita resulte fundamental para la toma de la decisión judicial, se entra a estudiar la exclusión probatoria según el art. 6.2, remitiéndose el proceso judicial de cada país. ${ }^{72}$ Sin embargo, esta exclusión no se hace en función de la violación de un derecho humano, sino por asuntos de autenticidad y contradicción de la prueba. ${ }^{73}$

Las posiciones de los casos Schenck y Malone se expusieron juntamente en los casos de P.G y J.H, y Khan, ambos contra Reino Unido, en los que hubo interceptaciones de comunicaciones y se usaron en procesos judiciales. En P.G y J.H y Khan encontramos que hay violación del art. 8.2 de la convención en cuanto hubo injerencias no acordes con los requerimientos legales, siguiendo en mucho el punto expuesto en el caso Malone $;^{74}$ pero en relación con el art. 6.1 (considerando que se alega la exclusión desde este) ambos casos consideran que se dio la oportunidad de alegar su autenticidad y contradecir la prueba, siguiendo la

72 Cfr., Armenta Deu, Teresa. Op. cit., pp. 161-163.

73 Cfr., CEDH, Caso Schenck c. Suiza. Sentencia de 12 de julio de 1988, párrs. 47-51.

74 Cfr., CEDH, Caso Khan v. Reino Unido. Sentencia de 12 de mayo de 2000, párrs. 22-28; Caso P.G y J.H v. Reino Unido. Sentencia de 25 de septiembre de 2001, párrs. 59, 60, 63; Caso Khan, curiosamente el Estado no es responsable por el art. 8.1 en cuanto se logra demostrar que la actuación de la Policía no fue arbitraria. Sin embargo, por la forma en que se adelantó la interceptación no se encuentra propiamente regulado en el Police Act 1997, y por tanto es responsable por el art. 8.2; en el caso $P$. $G$ y J. $H$ el Estado es responsable por los dos numerales del art. 8, porque hubo una vulneración del procedimiento establecido. Otro punto es que el método de análisis cambia respecto de como lo hace la $\mathrm{CIDH}$, en cuanto estos dos numerales se analizan de manera conjunta; sin embargo, la semejanza estaría más clara cuando se estudia según el art. 1.1 o 2 de la CADH. 
posición de Schenck. ${ }^{75,76} \mathrm{Si}$ bien los casos expuestos no se adelantan dentro de un contexto de conflicto armado, esta regla termina siendo base para el entendimiento de la regla de exclusión de la Corte Penal Internacional, como veremos en el siguiente capítulo.

\section{Conclusiones: aplicación a los tres casos expuestos}

Vemos que tanto el DiH en el art. 3 común a los Convenios de Ginebra como los diferentes instrumentos internacionales del DIDH consideran las “garantías judiciales" como un derecho que en todo momento debe cumplirse, incluso en los estados de excepción. Sin embargo, encontramos que dentro del listado de derechos que no admiten suspensión no se encuentra el derecho a la intimidad, por tanto sería viable que este pueda ser limitado; dicha limitación necesariamente tendrá que ser estudiada por un juez para revisar su proporcionalidad (a partir de su idoneidad, necesidad, y proporcionalidad en sentido estricto) con el fin que se busca, puesto que si este derecho es restringido y no pasa el análisis por parte del juez se considerará que fue vulnerado.

75 Cfr., CEDH, Caso Khan v. Reino Unido. Sentencia de 12 de mayo de 2000, párrs. 37, 38, 40; Caso P. G y J.H v. Reino Unido. Sentencia de 25 de septiembre de 2001, párrs. 76, 77, 79, 81.

76 Esta postura se sigue sosteniendo en los casos recientes de CEDH, Caso Niculescu v. Rumania. Sentencia 25 de junio de 2013, párrs. 98-102, 109-129; Caso Valentino Acatrinei v. Rumania. Sentencia de 25 de junio de 2013, párrs. 57-61, 66-85. 
Resulta interesante ver que la CIDH no ha tratado la exclusión probatoria dentro de este contexto, así como tampoco ha estudiado la exclusión probatoria en relación con injerencias en comunicaciones privadas. Sin embargo, la CEDH ha desarrollado una postura en relación con la exclusión probatoria en casos de injerencias en las comunicaciones privadas, con base en los casos Schenck y Malone; a la luz de la Corte Europea, entendemos que se estudia la exclusión al estudiar con el conjunto probatorio la exclusión se da cuando la prueba no pudo ser sometida a contradicción - o cuando hay deficiencias con respecto a su autenticidad - y no procede por la violación al derecho a la intimidad. Adicionalmente, es importante resaltar, por un lado, que respecto al caso Malone la producción probatoria debe cumplir los requerimientos legales debidamente establecidos, y por otra parte, que si bien estos casos no se estudian dentro de un contexto de conflicto armado, el TPIY tomará parte de esta postura, de este a la CPI.

1. En el caso del Sargento Segundo Juan Carlos Castillo encontramos que las interceptaciones que realizaron los organismos de inteligencia del Ejército sí afectaron el derecho a la intimidad; una lectura rápida permitiría argumentar que, a pesar de ello, estas injerencias en las comunicaciones podrían ser admitidas en el proceso penal. Pero como también lo plantea la doctrina Schenck, habría que hacer un análisis en conjunto con el proceso judicial doméstico; como en nuestro caso sabemos que la regla de exclusión 
es parte del CPP, un incumplimiento de esta norma también afectaría las garantías judiciales, por tanto también provocaría su exclusión.

2. En el caso de la masacre de Macayepo, se presentó la prueba y se pudo contradecir durante todo el proceso penal, así como su autenticidad se demuestra afirmando que estas fueron hechas por miembros de la SIPOL. En este caso, como vemos, la Corte Suprema de Justicia misma considera que estas captaciones incidentales, al ser tomadas en el espectro electromagnético, sucedieron en función de un deber legal y constitucional. En este orden de ideas, las pruebas no son excluidas, a pesar de que en efecto sí hubo una injerencia en la intimidad de la persona.

3. En el caso de la toma al Palacio de Justicia, lo que plantea el salvamento de voto con respecto a la autenticidad de las grabaciones toma mayor importancia, ya que este es un elemento esencial en lo adelantado por la CEDH. De igual forma, por el reenvío que se hace al sistema interno, sigue siendo sumamente delicada la contradicción que hay entre lo adelantado por la Corte Constitucional y lo argumentado por el Tribunal Superior de Bogotá, como se señaló en el capítulo primero.

Lo que plantea la doctrina Schenck, partiendo de que la prueba sea esencial para la toma de una decisión judicial, entrando a revisar los criterios de autenticidad y contradicción de la contraparte, terminan siendo los requerimientos 
mínimos que se han adelantado en esta materia en el DIDH. Sin embargo, el último punto, que exige estudiar las garantías judiciales a la luz del sistema judicial interno, en nuestro caso no produce mayores efectos porque tenemos la regla de exclusión dentro de nuestro propio sistema judicial en el art. 23 de CPP. 



\section{Capítulo tercero Licitud de las injerencias en las comunicaciones a la luz del derecho internacional penal}

\section{Introducción}

En este capítulo entramos a estudiar cómo se ha venido desarrollando la regla de exclusión más reciente del derecho internacional penal (DIP). Sin embargo, puesto que esta no ha tenido la misma evolución que en los tribunales ad hoc, también la estudiaremos a partir del desarrollo del Tribunal Penal Internacional para la ex-Yugoslavia (TPIY) y los aportes del Tribunal Penal Internacional para Ruanda (TPIR), ya que son muy similares. Finalmente, se revisará cómo se aplicaría la regla extraída de los puntos comunes del derecho internacional penal a los tres casos expuestos en la introducción del presente trabajo.

\subsection{Las interceptaciones a la Luz del Estatuto de Roma y la Corte Penal Internacional}

Antes de adentrarnos en este punto, es importante hacer una breve introducción al procedimiento de la CPI y algunos comentarios sobre la regulación probatoria, así como hemos hecho un resumen del procedimiento interno colombiano, 
para tener una visión panorámica de la legalidad procesal aplicable.

Para que se active la competencia de la CPI se requiere que se cumplan los requisitos de competencia que establece el Estatuto, teniendo en cuenta la materia de los delitos, el lugar donde se cometieron, el momento de los hechos y la persona a quien se investigue. ${ }^{1}$ Dependiendo de esto, lo primero es analizar el contexto donde se produjeron los hechos, lo que la Corte llama "situación”, o "abrir situación”. De esta manera, una de las situaciones que la Corte conoce son los conflictos armados, en cuanto que los crímenes de guerra hacen parte de su competencia gracias al art. 8. ${ }^{\circ}$ Después de un trabajo mancomunado entre la Sala de Cuestiones Preliminares y la Fiscalía, se abre una situación en concreto y se comienza a adelantar la investigación de casos propiamente dichos, los que deben tener una relación con la situación que se aprobó. ${ }^{2}$

El procedimiento ante la CPI principalmente se adelanta ante tres magistraturas. La primera de ellas es la Sala de Cuestiones Preliminares, la que aparte de revisar la apertu-

1 Revisar los arts. 5-17, 24-26, 53, 98, 124 del ER.

2 Cfr., Olásolo, Héctor. Corte Penal Internacional ¿Dónde investigar? Especial referencia a la Fiscalia en el proceso de activación. Edit. Tirant Lo Blanch, Cruz Roja Española. Valencia, 2002, p. 113; y Olásolo, Héctor. Admisibilidad de situaciones y casos objeto de procesos de justicia de transición ante la Corte Penal Internacional. En: Olásolo, Héctor. Ensayos de derecho penal y procesal internacional. Con inclusión de la lección inaugural de la Universidad de Utrecht (Holanda) dictada el 18 de octubre de 2010. Biblioteca Jurídica Diké, Instituto Iberoamericano de la Haya, Unión Europea, República de Colombia-Ministerio de Justicia y del Derecho. Bogotá, 2011, p. 124. 
ra de la situación, confirma los cargos que se le imputan al procesado. ${ }^{3}$ Posteriormente, ante la Sala de primera instancia se adelantará propiamente el juicio, donde se practicarán y debatirán las pruebas, se adelantarán los alegatos finales y se llegará a una sentencia en la que se fijará la absolución o condena y su pena. ${ }^{4}$ Contra esta sentencia caben los recursos de apelación y revisión ante la Sala de Apelaciones. ${ }^{5}$

Ahora, en materia probatoria, las tres salas tienen las mismas atribuciones, reguladas en el art. 69. 6 Para que se practiquen las pruebas se deberá tener en cuenta la pertinencia, admisibilidad, su valor probatorio, y si puede ocasionar algún perjuicio al proceso; ${ }^{7}$ se respetarán los derechos de la defensa, los privilegios de confidencialidad, salvo aquellos que sean hechos notorios. ${ }^{8}$ En el caso de que afecte uno de estos puntos, se podrán excluir las pruebas que hayan sido obtenidas violando derechos humanos internacionalmente reconocidos, y que además, o viole la fiabilidad de la prueba, o viole el Estatuto o la integridad del juicio.9

3 Cfr., Arts. 56-61 del ER.

4 Cfr., Arts. 62-80 del ER.

5 Cfr., Arts. 81-85 del ER.

6 Si bien el Estatuto no lo dice expresamente, se entiende esto en cuanto que el art. 69 hace parte de la práctica de evidencia en la Sala de Juicio, y se extiende este a la Sala de Apelaciones en concordancia al art. 83.1. Por su parte, a la Sala de Cuestiones Preliminares el art. 56.2.f le permite "adoptar las medidas necesarias para reunir o preservar las pruebas". mismo.

7 Cfr., art. 69.3 del ER en concordancia con los arts. 64, 69.4 y $69.8 \mathrm{del}$

$8 \quad$ Cfr., arts. 67, 69.5 y 69.6 del ER.

9 Cfr., art. 69.7 del ER. 


\subsubsection{La relación del DIH y el DIDH con el Estatuto de Roma (ER)}

$\mathrm{Al}$ aproximarse a los Crímenes de Guerra, dentro del art. 8. ${ }^{\circ}$, num. 2 del ER., con respecto a los conflictos armados no internacionales, el lit. c. hace una remisión directa al art. 3 común a los Convenios de Ginebra, y el lit. e. hace remisión mucho más amplia al decir "dentro del marco establecido de derecho internacional"; de esta manera no solo cabe la remisión al DIH y al DIDH sino a cualquier instrumento que pueda tener alguna aplicabilidad para los crímenes enlistados en el citado lit. e. Es importante señalar que el desarrollo jurisprudencial de la CPI se ha dado en menor medida que en otros organismos internacionales como el TPIY o el Tribunal Penal Internacional para Ruanda (TPIR). Ante esto precisamente el art. 21 del Estatuto, admite otras fuentes para aplicar e interpretar el ER y las Reglas de Procedimiento y Prueba (RPP). ${ }^{10}$

10 Conferencia Diplomática de plenipotenciarios de las Naciones Unidas. Estatuto de la Corte Penal Internacional (ER). Adoptada en Roma el 17 de julio de 1998.

Artículo 21. Derecho aplicable.

1. La Corte aplicará:

a) En primer lugar, el presente Estatuto, los Elementos de los crímenes y sus Reglas de Procedimiento y Prueba;

b) En segundo lugar, cuando proceda, los tratados aplicables, los principios y normas del derecho internacional, incluidos los principios establecidos del derecho internacional de los conflictos armados;

[...]

3. La aplicación e interpretación del derecho de conformidad con el presente artículo deberá ser compatible con los derechos humanos internacionalmente reconocidos, sin distinción alguna basada en motivos como el género, definido en el párrafo 3 del artículo 7, la edad, la raza, el color, el idioma, la religión o el credo, la opinión política o de otra índole, 
Así, para entender el ER primero se estudia aquello que se encuentre dentro de los Elementos de los Crímenes y de las RPP, seguidamente se estudia este cuerpo normativo en concordancia con los demás tratados aplicables, donde si bien nombra expresamente el DIH no excluye la aplicabilidad del DIDH ni la jurisprudencia de los diferentes tribunales internacionales como el TPIY o el TPIR, o las Cortes de Derechos Humanos. ${ }^{11}$ El num. 3 condiciona la aplicación y la interpretación del derecho a partir del artículo 21, debe ser compatible con el DIDH, y se prohíbe expresamente cualquier tratamiento discriminativo.

Por lo tanto, las garantías judiciales terminan siendo claves dentro del DIP, y dentro del contexto del conflicto armado no internacional: primero, porque el DIH establece en su art. 3 común la protección de las garantías judiciales; y segundo, por parte del DIDH, estas no podrán ser suspendidas en ningún momento.

el origen nacional, étnico o social, la posición económica, el nacimiento u otra condición.

11 Ante esto, el art. 38 del Estatuto de la Corte Internacional de Justicia dice:

1. La Corte, cuya función es decidir conforme al derecho internacional las controversias que le sean sometidas, deberá aplicar: a) las convenciones internacionales, sean generales o particulares, que establecen reglas expresamente reconocidas por los Estados litigantes; b) la costumbre internacional como prueba de una práctica generalmente aceptada como derecho; c) los principios generales de derecho reconocidos por las naciones civilizadas; $\mathrm{d}$ ) las decisiones judiciales y las doctrinas de los publicistas de mayor competencia de las distintas naciones, como medio auxiliar para la determinación de las reglas de derecho, sin perjuicio de lo dispuesto en el artículo 59; 2. La presente disposición no restringe la facultad de la Corte para decidir un litigio ex aequo et bono, si las partes así lo convinieren. 


\subsubsection{La admisibilidad de la prueba producida por injerencias a la intimidad ante la Corte Penal Internacional}

El art. 69 del ER trata de la prueba en concreto. En lo que respecta a nuestro interés, nos vamos a enfocar en la admisibilidad y la regla de exclusión regulados en los nums. 4 y 7 de dicho artículo:

Artículo 69 Práctica de las pruebas.

[...]

4. La Corte podrá decidir sobre la relevancia o admisibilidad de cualquier prueba, teniendo en cuenta, entre otras cosas, su valor probatorio y cualquier perjuicio que pueda suponer para un juicio justo o para la justa evaluación del testimonio de un testigo, de conformidad con las Reglas de Procedimiento y Prueba.

$[\ldots]$

7. No serán admisibles las pruebas obtenidas como resultado de una violación del presente Estatuto o de las normas de derechos humanos internacionalmente reconocidas cuando:

a) Esa violación suscite serias dudas sobre la fiabilidad de las pruebas; 0

b) Su admisión atente contra la integridad del juicio o redunde en grave desmedro de él. ${ }^{12}$

12 ER. Supra. n. 240. 
En las RPP de la CPI, su Regla 63.3 dice que "La Sala se pronunciará sobre las cuestiones de admisibilidad fundadas en las causales enunciadas en el párrafo 7 del artículo 69 que plantee una de las partes o ella misma de oficio de conformidad con el párrafo 9 a) del artículo $64 " .{ }^{13}$

Dicho reenvío faculta a la Sala de Primera Instancia, ya sea por petición de parte o de manera oficiosa, para decidir sobre la admisibilidad o pertinencia de las pruebas. Eso nos lleva a tratar la regla de exclusión de manera similar a la admisibilidad probatoria. Seguidamente, la Regla 64.1 dice:

Las cuestiones de pertinencia o admisibilidad deberán plantearse en el momento en que la prueba sea presentada ante una de las Salas. Excepcionalmente, podrán plantearse inmediatamente después de conocida la causal de falta de pertinencia o inadmisibilidad cuando no se haya conocido al momento en que la prueba haya sido presentada. La Sala podrá solicitar que la cuestión se plantee por escrito. La Corte transmitirá el escrito a todos los que participen en el proceso, a menos que decida otra cosa.

La regla 64.2 consiste en que "la sala expondrá las razones de los dictámenes que emitan sobre cuestiones de prueba” y dichas razones tendrán que constar en el expediente. La regla 64.3 trata de que las pruebas que se hayan declarado inadmisibles o impertinentes no serán valoradas. Si bien en

13 Corte Penal Internacional, Asamblea de los Estados Partes. Reglas de Procedimiento y Prueba. ICC-ASP/1/3 (Part. II-A) de 9 de septiembre de 2002. 
estas hay varios puntos de la admisibilidad que se estudian, la profesora Buisman los reduce a cuatro puntos: la relevancia, el valor probatorio, el perjuicio que pueda ocasionar en el proceso, y la fiabilidad. ${ }^{14}$ Sin embargo, nos vamos a concentrar en dos puntos comunes tanto en la admisibilidad como en la regla de exclusión: la fiabilidad de la prueba y el perjuicio de la prueba en el proceso. Si bien es cierto el art. 69.7 dice que para que se excluya una prueba se requiere que haya una violación del ER o de algún derecho internacionalmente reconocido, esto se tiene que analizar a la vista de estos dos puntos comunes. ${ }^{15}$ Sin embargo, es importante señalar que el enunciado general relaciona la violación con la normativa internacional, de tal manera que no toma la segunda parte de la postura de la doctrina Schenck, que corresponde en revisar el cumplimiento de las garantías judiciales a la luz del derecho interno.

Al tener en cuenta la regla 64, el momento procesal para estudiar la admisibilidad es cuando se presenta ante la Sala la

14 Buisman, Caroline. Evidence before International Criminal Courts and Tribunals. En Bantekas, Ilias International Criminal Law. 4. ${ }^{a}$ ed. Hart Publishing Ltd., Oxford, 2010, pp. 473-547; Cfr., Schabas, William A. The International Criminal Court: Comentary on the Rome Statute. Oxford University Press. Oxford, 2010, pp. 843-845. Hay que tener en cuenta que la CPI se enfoca en los tres primeros puntos y la fiabilidad se estudia desde la relevancia; Cfr., CPI, Situación de República Democrática del Congo. Sala de Primera Instancia I, Prosecutor v. Thomas Lubanga Dyilo. Corrigendum to Decision on the admissibility of four documents (ICC-01/04-01/06-1399-Corr) de 20 de enero de 2011, párrs. 26-32.

15 CPI, Situación de República Democrática del Congo. Sala de Cuestiones Preliminares I, Prosecutorv. Thomas Lubanga Dyilo. Decision on the confirmation of charges (ICC-01/04-01/06-803-tEN) de 29 de enero de 2007, párr. 84. 
prueba que se desea practicar. Sin embargo, también puede ser con posterioridad a que se presente la prueba dado que el art 64.9 amplía esta potestad a la Sala de Primera Instancia para estudiar la admisibilidad y relevancia sobre las pruebas; en concordancia con la regla 63.1, amplía todo el art. 64 del Estatuto a todas las Salas de la CPI. ${ }^{16}$ Hay que resaltar que este análisis no es solamente de la Sala de Primera Instancia, sino que también puede llegar a presentarse tanto en la Sala de Cuestiones Preliminares como en la Sala de Apelaciones. Esto sucede en función del art. 83.1 y 2 del ER y la regla 63.1 de las RPP, y por tanto se infiere que la regla de exclusión se puede dar en cualquier momento procesal. De esta manera, la regla de exclusión es uno de los mecanismos para remediar las infracciones a los derechos de las partes, principalmente los derechos del acusado. ${ }^{17}$

\subsubsection{La fiabilidad de la prueba}

Entre los diferentes medios probatorios - cada uno puede tener una reglamentación o exigencias propias - se destacan los siguientes: el testimonio, el reporte del investigador o

16 Cfr., CPI, Situación de la República Centroafricana. Sala de Apelaciones, Prosecutor v. Jean Pierre Bemba Gombo. Sentencia relativa a las apelaciones del Sr. Jean-Pierre Bemba Gombo y el fiscal contra la decisión de la Sala de Primera Instancia III titulada "Decisión relativa a la admisión como pruebas de los materiales contenidos en la lista de pruebas de la Fiscalía” (ICC-01/0501/08-1386-tSPA) de 3 de mayo de 2011, párr. 37.

17 Cfr., Cherif Bassiouni, Mahmoud. Issues Pertaining to the Evidentiary Part of International Criminal Law. En: Cherif Bassiouni, Mahmoud (Edit.) International Criminal Law. 3. . ed., Martinus Nijhoff Publishers, Leiden, 2008, pp. 597-598. 
forense, la prueba del perito o experto y la prueba documental. ${ }^{18}$ Por lo que entendemos, las interceptaciones de comunicaciones corresponderían más a una prueba documental, puesto que en esta cabrían las grabaciones por cualquier medio, como veremos más adelante.

Para que una prueba sea fiable se evalúa principalmente su procedencia, aunque no excluye otros elementos que las Salas pueden considerar relevantes, y por tanto se busca establecer su autenticidad a partir de saber quién es el autor del documento y su relación con el hecho o evento que se desea probar; por lo tanto, la cadena de custodia tiene un papel importante, que abarca desde el momento de creación el documento hasta cuando este se aporta a la Sala. Sin embargo, a pesar de que el documento pueda ser auténtico, no se puede inferir automáticamente su fiabilidad. ${ }^{19}$

Hay que tener en cuenta que la fiabilidad también hace parte del análisis sobre el valor probatorio de una prueba en concreto, enlazando así el art. 69.7 (a) con el art. 69.4 ER, puesto que la regla de exclusión consiste en estudiar si los medios técnicos o el método del cual se obtuvo la prueba y su preservación permite afirmar que esta es fiable, como es el

18 Cfr., Buisman, Caroline. Op. cit., pp. 487-521; Cfr., Cherif Bassiouni, Mahmoud Issues Pertaining to the Evidentiary Part of International Criminal Law... Op. cit., pp. 586-592.

19 Cfr., CPI, Situación de República Democrática del Congo. Sala de Primera Instancia II, Prosecutor v. Mathieu Ngudjolo. Judgment pursuant to article 74 of the Statute (ICC-01/04-02/12-3) de 18 de diciembre de 2012, párr. 57; Cfr., CPI, Situación de República Democrática del Congo. Sala de Primera Instancia I, Prosecutor v. Thomas Lubanga Dyilo. Judgment pursuant to article 74 of the Statute (ICC-01/04-01/06-2842) de 14 de marzo de 2012, párr. 109. 
caso de una ruptura de la cadena de custodia, donde no solo afecta la fiabilidad del art. 69.7 (a), sino que además afecta el valor probatorio del art. $69.4 .^{20}$ Con respecto al perjuicio al proceso, primero se hace un análisis de proporcionalidad entre el derecho reconocido internacionalmente con la fiabilidad de la prueba obtenida y, por tanto, la exclusión de la prueba se da cuando la vulneración de un derecho afecte esa fiabilidad. ${ }^{21}$ En el caso de que no prospere el análisis con el derecho internacional, la causal se adelantaría por el art. 69.7. (b).

Por otra parte, este procedimiento se rige por el principio de oralidad, teniendo en cuenta que se deben allegar al proceso las pruebas que busquen establecer la verdad de acuerdo con al art. 69.3 del Estatuto, y observando la protección de los derechos del acusado según el art. 64.2 del mismo. De esta manera, si bien es cierto que hay una referencia expresa a la oralidad por medio del art. 69.2, se puede utilizar cualquier medio de prueba que resulte necesario para probar un hecho; es decir, el ER acoge con amplitud el principio de libertad probatoria. ${ }^{22}$

20 Cfr., Schabas, William. The UN International Criminal Tribunals. The former Yugoslavia, Rwanda and Sierra Leona. Cambridge University Press, New York, 2006, pp. 456-457.

21 CPI, Situación de República Democrática del Congo. Sala de Cuestiones Preliminares I, Prosecutor v. Thomas Lubanga Dyilo. Decision on the confirmation of charges (ICC-01/04-01/06-803-tEN) de 29 de enero de 2007, párr. 85; TPIY, Sala de Primera Instancia, Prosecutor v. Karadžić, Radovan. Decision on the accused's motion to exclude Intercepted Conversations (IT-95-5/18-T) de 30 de septiembre de 2010, párr. 6.

22 Cfr., cPI, Situación de República Democrática del Congo. Sala de Cues- 


\subsubsection{El perjuicio al Estatuto o al juicio}

Con respecto al perjuicio al Estatuto, o del juicio mismo, se hace un análisis de proporcionalidad, pero en este caso es entre el deber de atacar la impunidad a partir de la responsabilidad del acusado ante las víctimas y la comunidad internacional, y la protección de un juicio justo y los demás derechos del acusado. ${ }^{23} \mathrm{~A}$ este respecto, corresponde estudiar en este punto cuándo se vulnera las RPP o directamente al Estatuto. ${ }^{24}$

En el caso Lubanga, donde se trata el derecho a la intimidad - dado que, tras un allanamiento, se incautan evidencias -, si bien este es violatorio del derecho interno (referente al Código de Procedimiento Congolés), el análisis se hace a la luz del ER, y por ello estas pruebas se admiten porque no se afecta la fiabilidad de las evidencias obtenidas argumentando desde los arts. 69.4 y 69.7..$^{25}$ Así, a pesar de que la prueba se obtuvo fuera de lo regulado por el derecho

tiones Preliminares I, Prosecutor v. Thomas Lubanga Dyilo. Corrigendum to Decision on the admissibility of four documents (ICC-01/04-01/06-1399-Corr) de 20 de enero de 2011, párrs. 19-25.

23 Cfr., CPI, Situación de República Democrática del Congo. Sala de Cuestiones Preliminares I, Prosecutor v. Thomas Lubanga Dyilo. Decision on the confirmation of charges (ICC-01/04-01/06-803-tEN) del 29 de enero de 2007, párr. 85; Cfr., TPIY, Sala de Primera Instancia. Prosecutor v. Karadžić, Radovan. Decision on the accused's motion to exclude Intercepted Conversations (IT-95-5/18-T) de 30 de septiembre de 2010, párr. 7.

24 Cfr., Buisman, Caroline. Op. cit., pp. 524-530.

25 Cfr., CPI, Situación de República Democrática del Congo. Sala de Cuestiones Preliminares I. Prosecutor v. Thomas Lubanga Dyilo. Decision on the confirmation of charges (ICC-01/04-01/06-803-tEN) de 29 de enero de 2007, párrs. 62, 90. 
doméstico, como es en este caso el de la República del Congo, no se afecta la decisión de admitir la prueba, a diferencia de como se trata en los sistemas de derechos humanos; por otra parte, en este allanamiento, si bien hubo una violación al derecho a la intimidad, parece no afectar ni el juicio ni el Estatuto de Roma.

La Sala de Cuestiones Preliminares II en el caso JeanPierre Bemba excluye la prueba referente a los comportamientos sexuales anteriores o posteriores de la víctima, cuando se trate de probar crímenes de violencia sexual según la regla $71 .{ }^{26}$ Schabas nos explica que en el common law el jurado puede ser injustamente influenciado por los comportamientos anteriores de la víctima y por tanto ello puede perjudicar el proceso. ${ }^{27}$ Sin embargo, la Sala de Primera Instancia declaró la admisibilidad de las pruebas a partir de un análisis en conjunto a partir de las listas de pruebas presentadas por las partes. ${ }^{28}$ Tal decisión fue apelada y la Sala de Apelaciones consideró que las pruebas se debían declarar inadmisibles, o en su defecto ser excluidos, según

26 Cfr., CPI, Situación de República Centroafricana, Sala de Cuestiones Preliminares II. Caso de Prosecutor v. Jean Pierre Bemba. Decision Pursuant to Article 61(7) (a) and (b) of the Rome Statute on the Charges of the Against Jean-Pierre Bemba Gombo (ICC-01/05-01/08) del 15 de junio de 2009, párrs. 46, 51.

27 Schabas, William A. The International Criminal Court... Op. cit., pp. 844,845 .

28 Cfr. CPI, Situación de República Centroafricana, Sala de Primera Instancia III, Caso de Prosecutor v. Jean Pierre Bemba, Decision on the admission into evidence of materials contained in the prosecution's list of evidence (ICC01/05-01/08-1022) de 19 de noviembre de 2010, párr. 35. 
la regla 71. El análisis debió hacerse evidencia por evidencia, y no a partir de una lista; por lo tanto, la Sala de Apelaciones revocó la decisión de primera instancia y confirmó lo planteado por la Sala de Cuestiones Preliminares. ${ }^{29}$ De esta manera, encontramos que el lit. b. del art. 69.7 del Estatuto se cumple cuando se vulneran derechos de las partes o lo reglado en la normatividad del ER o las RPP.

Vemos en el caso Callixte Mbarushimana que nuevamente se intenta excluir la interceptación de comunicaciones a partir de su falta de fiabilidad. Generalmente los medios probatorios producidos a partir de injerencias en las comunicaciones privadas, como es el caso de las interceptaciones, tiende a alegarse a partir de su falta de fiabilidad, mostrando que estas no son auténticas; esta es la principal vía para su exclusión, dado que el daño al derecho a la intimidad no alcanza el umbral necesario para la exclusión, como sí sucede con la tortura o tratamientos inhumanos. ${ }^{30}$ Esta postura es tomada del TPIY, como veremos seguidamente.

29 Cfr., CPI, Situación de República Centroafricana, Sala de Apelaciones, Caso de Prosecutor v. Jean-Pierre Bemba. "Sentencia relativa a las apelaciones del Sr. Jean-Pierre Bemba Gombo y el Fiscal contra la decisión de la Sala de Primera Instancia III, titulada 'Decisión relativa a la admisión como pruebas de los materiales contenidos en la lista de pruebas de la Fiscalía"” (ICC-01/0501/08-1386-tSPA) del 3 de mayo de 2011, párrs. 52, 53.

30 Cfr., CPI, Situación de República Democrática del Congo. Sala de Cuestiones Preliminares I, Prosecutor v. Callixte Mbarushimana. Decision on the confirmation of charges (ICC-01/04-01/10-465-Red) de 16 de diciembre de 2011, párrs. 71-74. 


\subsection{Las interceptaciones de comunicaciones a la luz del TPIY}

Vemos que la CPI no ha tenido el mismo desarrollo que ha tenido el TPIY. Por tal razón, gracias al art. 21, que trata el sistema de fuentes, nos permite remitirnos a este tribunal, sin dejar de lado las contribuciones del TPIR, al explicar de una mejor manera qué son las pruebas documentales y sus requisitos de fiabilidad.

\subsubsection{La admisibilidad de la prueba obtenida por injerencias a la intimidad ante el TPIY}

Resulta necesario revisar en conjunto los criterios de admisibilidad en el contexto del art. 89 de las RPP del TPIY:

Artículo 89.

Disposiciones generales (Aprobado el 11 de feb de 1994)

(a) La Sala deberá aplicar las reglas de la prueba establecidas en esta sección, y no estará obligado por las reglas nacionales de pruebas. (Modificado 13 dic de 2000).

(b) En los casos no previstos en la presente sección, la Sala deberá aplicar las reglas de evidencia que mejor favorezca a una determinación justa sobre el asunto y estar en consonancia con el espíritu del estatuto y los principios generales del derecho.

(c) La Sala podrá admitir la prueba relevante que considera tener valor probatorio.

(d) La Sala podrá excluir la prueba si su valor probatorio sea (sic) sustancialmente inferior a la necesidad de garantizar un juicio imparcial. 
(e) La Sala podrá solicitar la verificación de la autenticidad de la prueba obtenida fuera de los tribunales.

(f) La Sala podrá recibir el testimonio oralmente o, cuando los intereses de la justicia lo permita, en forma escrita (modificado 13 dic. de 2000). ${ }^{31}$

Este regla del TPIY es concordante con el art. 69.4 del ER, puesto que tienen en común el valor probatorio y la relevancia de la prueba. La regla de exclusión de la TPIY la encontramos en la regla 95:

\section{Regla 95.}

Exclusión de ciertas pruebas. (Aprobado 1994 de feb. 11, modificada 30 ene. de 1995, modificada 12 nov. de 1997) Ninguna prueba debe ser admisible si se obtuvo por métodos que arrojen dudas sustanciales sobre su fiabilidad o si su admisión va en contra y podría dañar seriamente la integridad del juicio. ${ }^{32}$

Sobre este punto es interesante ver que el enunciado general que plantea el art. 69.7 del ER se encuentra en la regla 89 (A) del TPIY. La diferencia consiste en que mientras en el TPIY por lo que dice la regla, se revisará solamente la viola-

31 Naciones Unidas, International Tribunal for the Prosecution of Persons Responsible for Serious Violations of International Humanitarian Law Committed in the Territory of the former Yugoslavia since 1991 (Tribunal Penal Internacional para la ex-Yugoslavia). Rules of procedure and evidence (IT/32/ Rev. 49) de 22 de mayo de 2013, regla 89.

32 Ibíd., regla 95. 
ción de su estatuto, en el ER, adicionalmente a su normativa, también está vinculado a las normas de derechos humanos internacionalmente reconocidos. Pero en cualquier caso, para que la regla de exclusión prospere se deberá afectar la fiabilidad de la prueba o que le produzca un perjuicio al proceso.

Es importante hacer dos precisiones: primero, cuando se estudia la fiabilidad de la prueba, se está estudiando al mismo tiempo su valor probatorio y su relevancia, puesto que si se considera, por ejemplo, que se rompe la cadena de custodia, la prueba deja de ser fiable, pierde su capacidad probatoria y deja de ser relevante en el proceso; segundo, cuando el ER y las RPP del TPIY regulan que se revisará la normativa que rige estos foros internacionales, se deja de lado uno de los puntos que trata la doctrina Schenck, que es el reenvío a los sistemas judiciales domésticos.

\subsubsection{La fiabilidad de la prueba}

Ahora, por la naturaleza de la interceptación de comunicaciones, el medio probatorio para introducirlas al proceso sería la prueba documental, ${ }^{33}$ la cual el TPIY ha entendido de la siguiente forma:

La prueba documental se compone de documentos como prueba para su evaluación por el Tribunal. A los efectos

33 TPIy, Sala de Primera Instancia, Prosecutorv. Karadžić, Radovan. Decision on the prosecution's motion for judicial notice of intercepts related to the Sarajevo component and request for leave to add one document to the rule 65 ter exhibit list (IT-95-5/18-T) de 4 de febrero de 2011, párr. 17. 
de este caso, el término 'documento' se interpreta en términos generales, se entiende que supone cualquier cosa en donde la información descrita es guardada. Esta interpretación es lo suficientemente amplia como para abarcar no sólo los documentos por escrito, sino también mapas, croquis, planos, calendarios, gráficos, dibujos, registros computarizados, registros mecánicos, registros electro-magnéticos, registros digitales, bases de datos, pistas de sonido, cintas de audio, cintas de video, fotografías, diapositivas y negativos. Muchos, aunque no todos, de estos tipos de documentos se produjeron en este caso por ambas partes en soporte de sus respectivos casos. ${ }^{34}$

Sin embargo, el TPIR ha aportado puntos importantes que se deben tener en cuenta para el análisis de este tipo de pruebas. Caroline Buisman, tomando como base el caso de Bogosora, ha señalado los siguientes puntos:

34 TPIR, Sala de Apelaciones, Prosecutor v. Musema (ICTR-96-13-A) de 27 de enero de 2000, párr. 53. (Traducción libre) Dice textualmente:

Documentary evidence consists of documents produced as evidence for evaluation by the Tribunal. For the purposes of this case, the term 'document' is interpreted broadly, being understood to mean anything in which information of any description is recorded. This interpretation is wide enough to cover not only documents in writing, but also maps, sketches, plans, calendars, graphs, drawings, computerized records, mechanical records, electro-magnetic records, digital records, databases, sound tracks, audio-tapes, video-tapes, photographs, slides and negatives. Many, though not all, of these types of documents were produced in this case by both parties in support of their respective cases.

Cfr., Cherif Bassiouni, Mahmoud. Introduction to International Criminal Law: Second Revised Edition. Editorial Martinus Nijhoff Publischers, Leiden, 2013, p. 863. 


\section{El lugar donde el documento fue incautado}

2. La cadena de custodia luego de la incautación del documento

3. Corroboración del contenido del documento con otras evidencias

4. La naturaleza del documento por sí mismo tal como la firma, sello, o la escritura a mano. ${ }^{35}$

Por otra parte, en el caso Musema se enumeran otros puntos adicionales que resultan relevantes para su análisis, como son:

1. Si el documento presentado a la Sala es un original o una copia. Los originales tendrán, por regla general, un valor probatorio mayor que las copias;

2. Si un documento es copia, es en modo alguno registrado o inscrito con cierta autoridad institucional;

3. Si se firma el documento, sellado, certificado, estampado o de cualquier otra manera oficialmente autorizado por una autoridad u organización;

4. Si el documento ha sido debidamente ejecutado. En términos generales, esto consiste en mostrar que fue escrito, producido o autorizado por la persona o parte quien pretende ser escrito, producido o autorizado. ${ }^{36}$

35 Buisman, Caroline. Op. cit., p. 505. Citando, entre otros, a: TPIR, Sala de Primera Instancia, Prosecutor v. Bogosora et al. Decision on admission of tab 19 of binder produced in connection with appearance of witness Maxwell Nkole (ICTR-98-41-T) de 13 de septiembre de 2004, párr. 8.

36 Cfr., tPIR, Sala de Primera Instancia, Caso Prosecutor v. Musema. Jud- 
De acuerdo con esto, podemos entender que no es una lista cerrada y por tanto se estudian diversos aspectos que traten la fiabilidad de la prueba según la lógica y la sana crítica, y por tal razón la cadena de custodia, el autor del documento y el procedimiento en que se produjo el documento terminan siendo de considerable importancia. Por ello, la parte que decida aportar una interceptación tiene que demostrar de manera específica y clara por qué la prueba es relevante y fiable, estudiando principalmente la autenticidad, y posteriormente la Sala revisa si la prueba perjudica al proceso o algún derecho del acusado. ${ }^{37}$

En el caso de interceptaciones, se estudia a los operadores o funcionarios que realizan la interceptación, y/o los participantes de la conversación. ${ }^{38}$ En algunos casos encontramos

gement (ICTR-96-13-A) del 27 de enero de 2000, párr. 67. (Traducción libre) Dice textualmente:

Whether the document provided to the Chamber is an original or a copy. Originals will, as a general rule, have a higher probative value than copies; whether, a document being a copy, is in any way registered or enrolled with some institutional authority; whether the document is signed, sealed, certified, stamped or in any other way officially authorized by some authority or organization; whether or not the document has been duly executed. In general terms this involves showing that it was written, produced or authorized by the person or party by whom it purports to be written, produced or authorized.

37 Cfr., TPIY, Sala de Primera Instancia, Prosecutor v. Mladic, Ratko. Decision on prosecution's bar table motion for the admission of intercepts: Srebrenica segment (IT-09-92-T) de 2 de mayo de 2013, párrs. 16, 17; y TPIY, Sala de Primera Instancia, Prosecutor v. Karadžić, Radovan. Decision on prosecution's third bar table motion for the admission of intercepts (Srebrenica) (IT-95-5/18T) de 24 de mayo de 2012, párr. 9.

38 Cfr., tPry, Sala de Primera Instancia, Prosecutor v. Karadžić, Radovan. Decision on the prosecution's motion for judicial notice of intercepts related 
que el testigo por el cual se incorpora puede ser perito, o testigo experto, para garantizar que la conversación que se haya grabado pueda ser reconocida; para ello se pueden utilizar investigadores directamente de la oficina de la Fiscalía, o expertos en radio comunicaciones, donde no solamente se debate sobre la autenticidad de las grabaciones, dado que en algunos casos se ha discutido la fabricación de conversaciones, y además se pueda garantizar el cumplimiento de la cadena de custodia para que estas no sufran modificaciones o manipulaciones. ${ }^{39}$ De esta manera, podemos afirmar que cuando en apreciación de la prueba se estudia la fiabilidad, también se revisa su autenticidad, cumpliendo así el requerimiento establecido por el CEDH en el caso Scbenck.

Sin embargo, la mejor forma para aportar un documento al proceso es por medio de un testigo con la capacidad de responder las preguntas de las partes $y$, en especial, para que el acusado pueda contrainterrogar la prueba de cargo, garantizando el principio de contradicción. ${ }^{40}$

to the Sarajevo component and request for leave to add one document to the rule 65 ter exhibit list (IT-95-5/18-T) de 4 de febrero de 2011, párrs. 11-17, 27; y TPIY, Sala de Primera Instancia, Prosecutor v. Tolimir, Zdravko. Decision on prosecution's motion for admission of 28 intercepts from the bar table (IT05-88/2-T) de 20 de enero de 2012, párr. 14.

39 Cfr., TPIY, Sala de Primera Instancia, Prosecutorv. Popovic et al. Decision on Admisibility of intercepted communication (IT-05-88-T) de 7 de diciembre de 2007, párrs. 46, 54, 66-77; y TPIY, Sala de Primera instancia, Prosecutor v. Blagojevic and Jokic. Decision on the Admission into Evidence of Interceptrelated Materials (IT-02-60-T) de 18 de diciembre de 2003, párrs. 21-26.

40 Cfr., TPiy, Sala de Primera Instancia, Prosecutor v. Karadžić, Radovan. Decision on prosecution's first bar table motion for the admission of intercepts (IT-95-5/18-T), de 14 de mayo de 2012, párrs. 11; y TPIY, Sala de Primera 


\subsubsection{El perjuicio al Estatuto o al juicio}

A diferencia de lo que ha podido adelantar la CPI con respecto a este punto, es en el TPIY donde se ha trabajado más a fondo este tema. En este tribunal, en el caso Brdanin, se considera que aunque el derecho a la intimidad es un derecho internacionalmente reconocido, no es absoluto e incluso puede llegar a ser suspendido en estados de excepción, y las injerencias tienen que ser acordes a lo que regule la ley. ${ }^{41}$ Ahora, si bien es cierto una prueba que no se encuentra de acuerdo con lo regulado por la ley puede ser considerada ilícita, su admisión o su exclusión, según el caso, puede ser analizada bajo tres métodos:

1. En primer lugar, la propia ley establezca expresamente la exclusión automática de cualquier evidencia que haya sido ilegalmente o de otro modo obtenido indebidamente;

2. En segundo lugar, la cuestión de la exclusión o la admisión de dichas pruebas se puede dejar como un asunto a la discreción del juez que tiene el deber judicial para garantizar la imparcialidad hacia los acusados.

Instancia, Prosecutor v. Karadžić, Radovan. Decision on accused's motion for reconsideration of denial of defence intercepts (IT-95-5/18-T) de 22 de enero de 2013, párrs. 8, 9; y TPIY, Sala de Primera Instancia, Prosecutor v. Tolimir, $Z d r a v k o$. Decision on prosecution's motion for admission of 28 intercepts from the bar table (IT-05-88/2-T) de 20 de enero de 2012, párr. 15.

41 Cfr., TPIY, Sala de Primera Instancia, Caso Prosecutor v. Brdanin, Radoslav. Decision on the defence objection to intercept evidence (IT -99-36-T) de 3 de octubre de 2003, párrs. 30, 31. 
3. En tercer lugar, los tribunales pueden ocuparse sólo con la calidad de las pruebas y no tener en cuenta su procedencia en absoluto; en otras palabras, los tribunales sólo tratarían de averiguar si la prueba es pertinente, confiable y si tiene valor probatorio, independientemente de las cuestiones de si la evidencia se obtuvo legal o ilegalmente. ${ }^{42}$

El primer tipo de la regla de exclusión es el que principalmente se utiliza en los países de sistema continental, como es el caso colombiano, y las otras dos se usan principalmente en el common law. Ahora, el segundo tipo de exclusión es el sistema que principalmente utiliza el sistema norteamericano, mientras que el sistema inglés utiliza la tercera forma. ${ }^{43}$ En el ámbito internacional, el TPIY ha tenido en cuenta principalmente la postura de la $\mathrm{CEDH}$, la que toma los dos tipos de exclusión probatoria del sistema consuetudinario, adicionando que en el caso de que se cometa una violación a un derecho se debe tener un recurso efectivo para su protección; por tal razón, si bien se puede vulnerar el derecho a la intimidad, se revisa el derecho a un recurso efectivo y el debido proceso, tomando la postura del caso Schenck. ${ }^{44}$ Siendo así, como bien resalta el profesor Klamberg, las in-

42 Cfr., ibíd., párr. 33.

43 Cfr., ibíd., párrs. 35-40.

44 Cfr., ibíd., párrs. 42-52. Citando a: CEDH, Caso Saunders v. Reino Unido, Caso Teixeira v. Portugal, Caso Schenk v. Suiza, Caso Khan v. Reino Unido, Caso P.G. and J.H. v. Reino Unido. Es importante resaltar que estudiar el debido proceso también incluye la regulación interna para que se puedan adelantar 
terceptaciones de comunicaciones no necesariamente afectan la integridad del proceso. ${ }^{45}$

Lo anterior se reafirma en la decisión oral en el caso Kordic, en el que se considera que el espionaje a partir de la interceptación de llamadas durante la guerra no afecta la integridad del proceso y por tal razón no se excluye. ${ }^{46}$ Las RPP del tribunal en esta materia no regulan la exclusión por la vulneración de un derecho concreto, como sucede en nuestro sistema doméstico, ${ }^{47}$ sino que se analiza a la luz de las garantías judiciales, como lo ha establecido la CEDH, situación que también sucede ante la CPI, solamente con respecto al análisis de la autenticidad de la prueba y haber otorgado la posibilidad de controvertirla, mas no se hace una remisión a los sistemas nacionales puesto que el procedimiento base es el del foro internacional, ya sea el del TPIY o el de la CPI. La exclusión de pruebas que son relevantes y tienen valor probatorio puede llegar a ser un obstáculo para la administración de justicia, y más aún cuando el ejercicio de esta contribuye a la restitución de la paz. ${ }^{48}$

las interceptaciones de comunicaciones; y CEDH, Caso Malone v. Reino Unido. Sentencia de 2 de agosto 1984.

45 Cfr., Klamberg, Mark. Evidence in international criminal Trials. Confronting legal Gaps and the Reconstruction of Disputed Events. Editorial Martinus Nijhoff Publishers, Leiden, 2013, p. 400.

46 Cfr., ibíd., párr. 53. Citando a: TPIY, Sala de Primera Instancia, Caso Prosecutor v Kordic and Cerkez (IT -99-36-T). Decisión oral del 2 de febrero de 2000. Transcripción 13694.

47 Cfr., ibíd., párr. 55.

48 Cfr., ibíd., párrs. 63, 67, citando a: TPIY, Sala de Primera Instancia, Pro- 
En el caso Celebici, se encuentra que hay una exclusión de la prueba en cuanto el procesado no contó con abogado durante el interrogatorio; y en el caso Martic se considera que la forma en que se consiguió el material probatorio no fue voluntario, sino que se obtuvo a partir de una conducta opresiva. ${ }^{49}$ En este caso encontramos, por una parte, que si una conducta se puede considerar como opresiva no es admisible bajo la regla 95 del TPIY, ${ }^{50}$ y también cuando una prueba puede vulnerar otro derecho, por fuera de una conducta opresiva, pareciera ser que se revisa bajo el estándar del caso Schenck en cuanto que se debe garantizar al procesado que pueda contradecir la prueba a partir de la autenticidad, relevancia y valor probatorio.

Por tal razón, en el caso Celebici no se admite la prueba por falta de representación de un abogado, y con ello no tendría cómo contradecir o alegar sobre el interrogatorio, pero en el caso de las interceptaciones no se afecta la integridad del proceso y no se logra desvirtuar la autenticidad de estas. Sin embargo, el caso Martic hace una exclusión debido a que la prueba se obtuvo con una conducta opresiva, lo cual per-

secutor v. Delalic et al. Decision On The Tendering Of Prosecution Exhibits 104-108 (IT-96-21-T) de 9 de febrero de 1998, párrs. 18-20.

49 Cfr., Klamberg, Marck. Op. cit., p. 401, citando a: TPIY, Sala de Primera Instancia, Prosecutor v. Delalic et al. Decision on Zdravko Mucic's motion for the exclusion of evidence (IT-96-21-T) de 2 de septiembre de 1997, párrs. 50-55; y тPIY, Sala de Primera Instancia, Prosecutor v. Martic, Milan. Decision adopting guidelines on the standards governing the admission of evidence (IT95-11-T) de 19 de enero de 2006, párr. 9.

50 Cfr., Klamberg, Marck. Op. cit., p. 402. 
judica al proceso, es decir que no necesariamente tiene que catalogarse como tortura para que proceda una exclusión.

En este orden de ideas, habría que revisar cuáles son los umbrales que afectan la regla 95 del TPIY. En el caso del ER, hay que estudiarlo como un todo para poder entender sus principios y valores que se encuentran reconocidos en el proceso establecido, principalmente los derechos de la defensa, y podrá ser interpretado según el DIH y el DIDH. ${ }^{51}$ Si bien se pueden encontrar diferentes principios, muchos de ellos se hallan regulados por los diferentes instrumentos internacionales relacionados con las garantías judiciales, y la dogmática ya ha podido reconocer algunos, como es el caso de la asesoría de un abogado o el descubrimiento probatorio, teniendo como remedio ante estas vulneraciones la exclusión de la prueba. ${ }^{52}$

\subsection{Casos de interceptaciones de comunicaciones en el desplazamiento forzado de Srebrenica}

Dado que la CPI no ha desarrollado suficientemente este tema, nos enfocamos en el TPIY para explicar de manera general el desplazamiento forzado de Srebrenica a partir de tres casos: Radislav Krstic, Zdravko Tolimir, Popovic et al. En estos, a diferencia de lo que sucede en los sistemas

51 Cfr., Klamberg, Marck. Op. cit., p. 405. Sin embargo, aquí se abre la pregunta, como en el caso Martic, si correspondería más a una regla de exclusión del sistema continental.

52 Cfr., Cherif Bassiouni, Mahmoud. Introduction to International Criminal Law... Op. cit., pp. 838-861. 
de derechos humanos, se estudiaron las interceptaciones de comunicaciones dentro del contexto de conflicto armado, siendo útiles para demostrar la planeación y la ejecución del desplazamiento forzado. Para ello, primero se explicará de manera general la desintegración de la ex-Yugoslavia y la formación de Bosnia y Herzegovina, luego expondremos los hechos ocurridos entre el 28 de junio y 12 de julio de 1995, cuando sucedió el desplazamiento forzado, y terminamos con las apreciaciones del Tribunal sobre las interceptaciones que allí sucedieron.

\subsubsection{Contexto grosso modo de Yugoslavia}

La región de Yugoslavia (tierra de los eslavos del sur) está comprendida entre el sur de Austria y el norte de Grecia, sobre los montes Balcanes, frente a Italia y separada de ella por el mar Adriático; es de textura muy accidentada, lo cual influye en que los poblados tiendan a ser estables y aislados. Esa situación geográfica permite explicar que a lo largo de la historia el norte (Eslovenia y Croacia) haya tenido especial influencia de Europa occidental, con sus resultados culturales como idioma y religión romana, mientras el centro y sur (Serbia, Bosnia-Herzegovina, Montenegro, Macedonia) tuvieron especial influencia griega y por lo tanto el alfabeto cirílico y la religión ortodoxa (cristiana del Imperio bizantino). La cultura musulmana del Imperio otomano buscó por muchos años derribar el Imperio romano de oriente y finalmente lo logró en 1453, y en su expansión estableció 
amplias comunidades en los Balcanes, incluso mayoritarias en muchas provincias. ${ }^{53}$

Al terminar la Segunda Guerra Mundial las seis repúblicas (Eslovenia, Croacia, Serbia, Bosnia-Herzegovina, Montenegro y Macedonia) conformaron la República Socialista Federal de Yugoslavia y lograron una destacada estabilidad y progreso, aunque siempre existieron tensiones por los diferentes factores que conforman las nacionalidades. Con la muerte del mariscal Joseph Broz Tito y la decadencia del socialismo europeo al finalizar la Guerra Fría, esas tensiones se exacerbaron. Croacia y Eslovenia declararon su independencia y la consolidaron tras una corta guerra. Después lo hizo Serbia, más tarde Macedonia, y finalmente Bosnia-Herzegovina y Montenegro. ${ }^{54}$

En Bosnia-Herzegovina se hizo especialmente difícil la definición de nacionalidades como Estados, pues la población estaba más mezclada, aunque no integrada. La presencia de bosnio-musulmanes (44\%), bosnio-serbios (31\%), y bosnio-croatas (17\%), donde muy pocas personas se declaraban simplemente bosnios o yugoslavos, y las pretensiones de pureza étnica, posiblemente recogiendo unidad idiomática, religiosa, o cultural, más la intervención de fuerzas extranjeras paramilitares comprometidas con cada una de las etnias o culturas involucradas, es la base so-

53 Asimov, Issac. Cronología del mundo. La bistoria del mundo desde el Big Bang a los tiempos modernos. Arial Ciencia. Barcelona, 1992, pp. 148, 149, 264, 265, 280, 281, 690-692.

54 Cfr., TPIY, Sala de Primera Instancia, Prosecutor v. Krstic, Radislav. Judgement (IT-98-33-T) de 2 de agosto de 2001, párrs. 7, 8, 9. 
bre la cual se desarrollan los actos de guerra en la que cada una buscaba un control territorial, y tienen lugar crímenes internacionales que obligan a la Naciones Unidas a crear el TPIY. Al este de Bosnia-Herzegovina, limitando con Serbia, cuya frontera es el río Drina, la principal tensión se daba entre los bosnios-serbios y los bosnios-musulmanes.

\section{Gráfico 1. Mapa de Bosnia y Herzegovina}

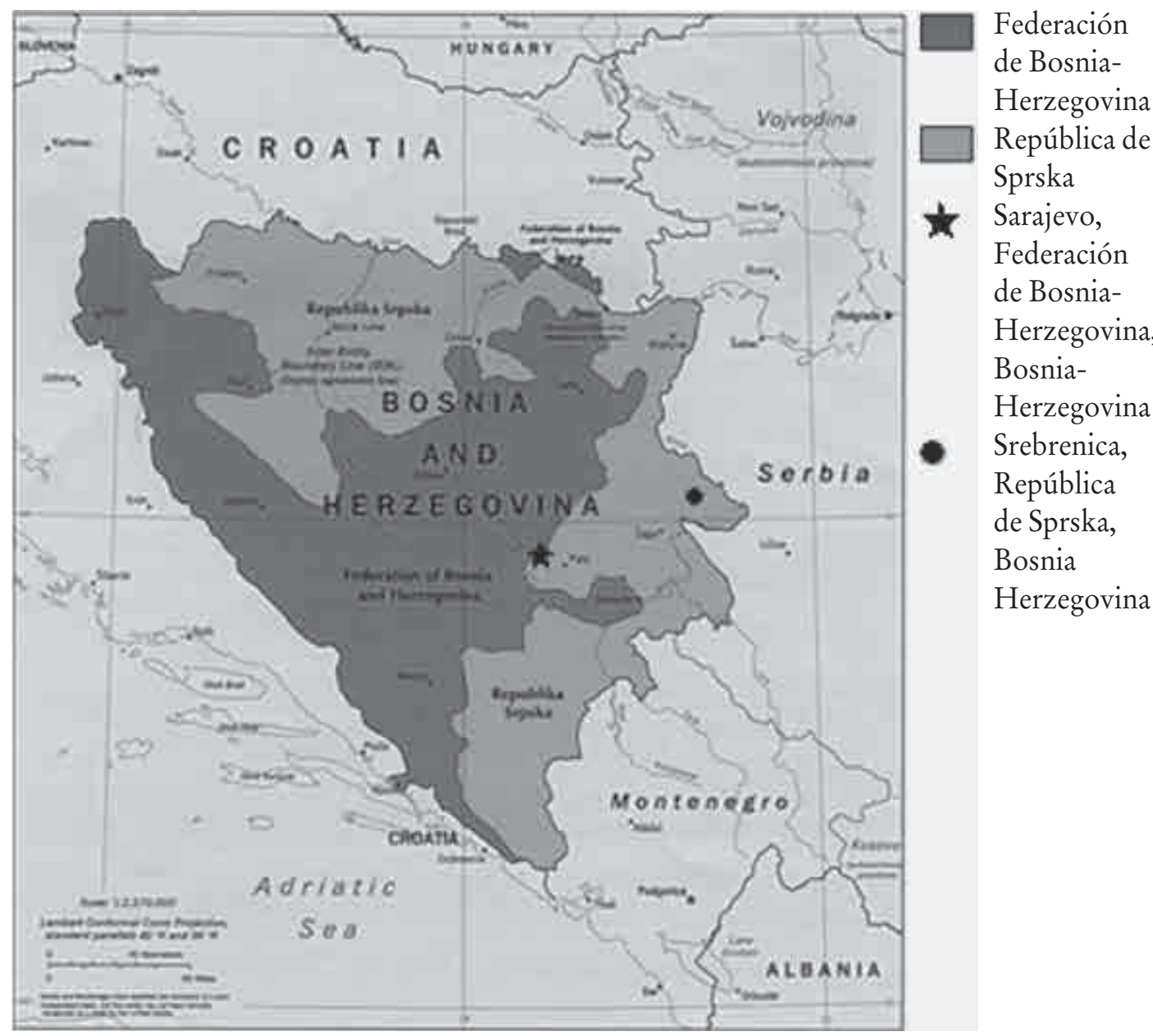

*Modificado sobre el mapa de Bosnia Herzegovina de la Universidad de Texas.

Fuente: http://www.lib.utexas.edu/maps/europe/bosnia_herzegovina/_pol97.jpg

Para 1991, Srebrenica era una ciudad con una población de un $73 \%$ bosnio-musulmán y un $25 \%$ bosnio-serbia, a 15 
kilómetros de la República de Serbia. Pese al porcentaje de los bosnios-musulmanes en Srebrenica, los bosnios-serbios querían tomar control de esta región para tener a los "Estados serbios" juntos..$^{55}$ El 12 de mayo de 1992 la asamblea compuesta por los representantes de los bosnios serbios establece como objetivo constituir un corredor en el valle del río Drina, de tal manera que se separarían las dos etnias; en dicho territorio solo habría bosnios-serbios y constituirían la República de Srpska (Rs) ${ }^{56}$ como un Estado federado de Bosnia-Herzegovina.

El 16 de abril de 1993 el Consejo de Seguridad de las Naciones Unidas, con la Resolución 819, declara “área segura" a Srebrenica y sus alrededores (constituyendo el enclave de Srebrenica), que implicaba su desmilitarización. Por tal resolución, intervienen las Fuerzas de Protección de las Naciones Unidas (UNPROFOR) y hace presencia el Alto Comisionado de las Naciones Unidas para los Refugiados (UNHCR); se intenta evacuar a los bosnios musulmanes de esa región, pero el gobierno de estos se opone. ${ }^{57}$

\subsubsection{Desplazamiento forzado de la ciudad de Srebrenica}

El 28 de junio de 1995, el presidente de la Rs, Radovan Karadzic, y por tanto supremo comandante del Ejército de la RS (VRs) se comunicó con el mayor general Radislav Krstic,

55 Cfr., ibíd., párrs. 12, 13.

56 Cfr., TPIY, Sala de Primera Instancia, Caso Prosecutorv. Tolimir, Zdravko. Judgement (IT-05-88/2-T) del 12 de diciembre de 2012, párr. 162.

57 Cfr., ibíd., párr. 176. 
jefe de personal del Cuerpo Drina, ${ }^{58}$ siendo este parte del VRS, para preguntarle cuánto tiempo se necesita para tomar Srebrenica; este le respondió que aproximadamente cinco días, y así se comenzó a montar el plan de combate, cuyo nombre es "Krivaja 95" ${ }^{59} \mathrm{El} 2$ de julio se movilizaron ocho brigadas del Cuerpo Drina para preparar el ataque, y para ello tenían como objetivo separar los enclaves de Srebrenica y Zepa, ${ }^{60}$ reducir las áreas urbanas, posteriormente mejorar sus posiciones tácticas y eliminar los enclaves. ${ }^{61}$ En el enclave de Srebrenica el vrs estimaba la presencia de diez mil hombres de la $28^{\text {th }}$ División del Ejército de Bosnia-Herzegovina (A.BiH), pero el Batallón Holandés (DutchBat), que era parte de la UNPROFOR, calculaba la presencia entre tres mil y cuatro mil hombres. ${ }^{62}$

El 5 de julio se divide Krivaja 95 en dos grupos tácticos, se posicionan, y el combate empieza el 6 de julio a las tres de la mañana. El 7 de julio sigue el combate pero se comienza a bombardear el enclave de Srebrenica, y de igual forma se ataca el complejo del DutchBat en Potocari, un pueblo al

58 No sobra explicar que el Cuerpo Drina hace parte del vRs, y este a su vez se divide en Brigadas.

59 Cfr., tPIY, Sala de Primera Instancia, Caso Prosecutor v. Popovic et al. Judgment (IT-05-88-T) del 10 junio de 2010, párrs. 242, 243. brenica.

60 El enclave de Zepa es colindante al sur occidente del enclave de Sre-

61 Cfr., TPiy, Sala de Primera Instancia, Caso Prosecutor v. Tolimir, Zdravko. Judgment (IT-05-88/2-T) del 12 de diciembre de 2012, párr. 817; y TPIY, Sala de Primera Instancia, Prosecutor v. Krstic, Radislav. Judgment (IT-98-33-T) del 2 de agosto de 2001, párr. 120.

62 Cfr., tPiy, Sala de Primera Instancia, Prosecutor v. Popovic et al. Judgement (IT-05-88-T) del 10 junio de 2010, párr. 246. 
norte de la ciudad de Srebrenica. ${ }^{63}$ El 9 de julio se cambia el objetivo de reducir el área urbana del enclave, por el de tomar la ciudad. ${ }^{64} \mathrm{El} 10$ de julio distintos pueblos del enclave estaban siendo atacados, y eso lleva a que la mayoría de los bosnios-musulmanes se concentren en la ciudad de Srebrenica; esa misma noche el A.вiH. decide dejarla, tomando control el vRs de la ciudad el 11 de julio. Ese día se declara como municipio Serbio de Srebrenica. ${ }^{65}$

El 10 de julio, el vrs comenzó a movilizar varios miles de bosnios-musulmanes a Potocari, siendo recibidos por el DutchBat. ${ }^{66}$ Sin embargo, este batallón solo tuvo la capacidad de albergar entre 4.000 y 5.000 personas, y por tanto no pudieron seguir entrando al complejo del Batallón y ello lleva a que aproximadamente unos 20.000 bosnio-musulmanes quedaron esparcidos alrededor del complejo. ${ }^{67}$

63 Ibíd., párr. 249; Cfr., TPIY, Prosecutor v. Tolimir, Zdravko. Judgment (IT-05-88/2-T) del 12 de diciembre de 2012, párrs. 219, 220.

64 Cfr., TPIY, Sala de Primera Instancia, Prosecutor v. Popovic et al. Judgement (IT-05-88-T) del 10 junio de 2010, párr. 252; Cfr., TPIY, Caso Prosecutor v. Tolimir, Zdravko. Judgment (IT-05-88/2-T) del 12 de diciembre de 2012, párrs 226.

65 Cfr., TPiy, Sala de Primera Instancia, Prosecutor v. Popovic et al. Judgement (IT-05-88-T) del 10 junio de 2010, párrs. 255, 260, 262.

66 Cfr., TPIY, Sala de Primera Instancia, Prosecutor v. Popovic et al. Judgement (IT-05-88-T) del 10 junio de 2010, párrs. 257, 264, 266; y TPIY, Caso Prosecutorv. Tolimir, Zdravko. Judgement (IT-05-88/2-T) del 12 de diciembre de 2012, párrs. 233, 238, 241.

67 Cfr., tpiy, Sala de Primera Instancia, Prosecutor v. Popovic et al. Judgement (IT-05-88-T) del 10 junio de 2010, párr. 266; TPIY, Caso Prosecutor v. Tolimir, Zdravko. Judgement (IT-05-88/2-T) del 12 de diciembre de 2012, párr. 241; y TPIY, Caso Prosecutor v. Krstic, Radislav. Judgement (IT-98-33-T) del 2 de agosto de 2001, párr. 129. 


\section{Gráfico 2. Mapa de la región}

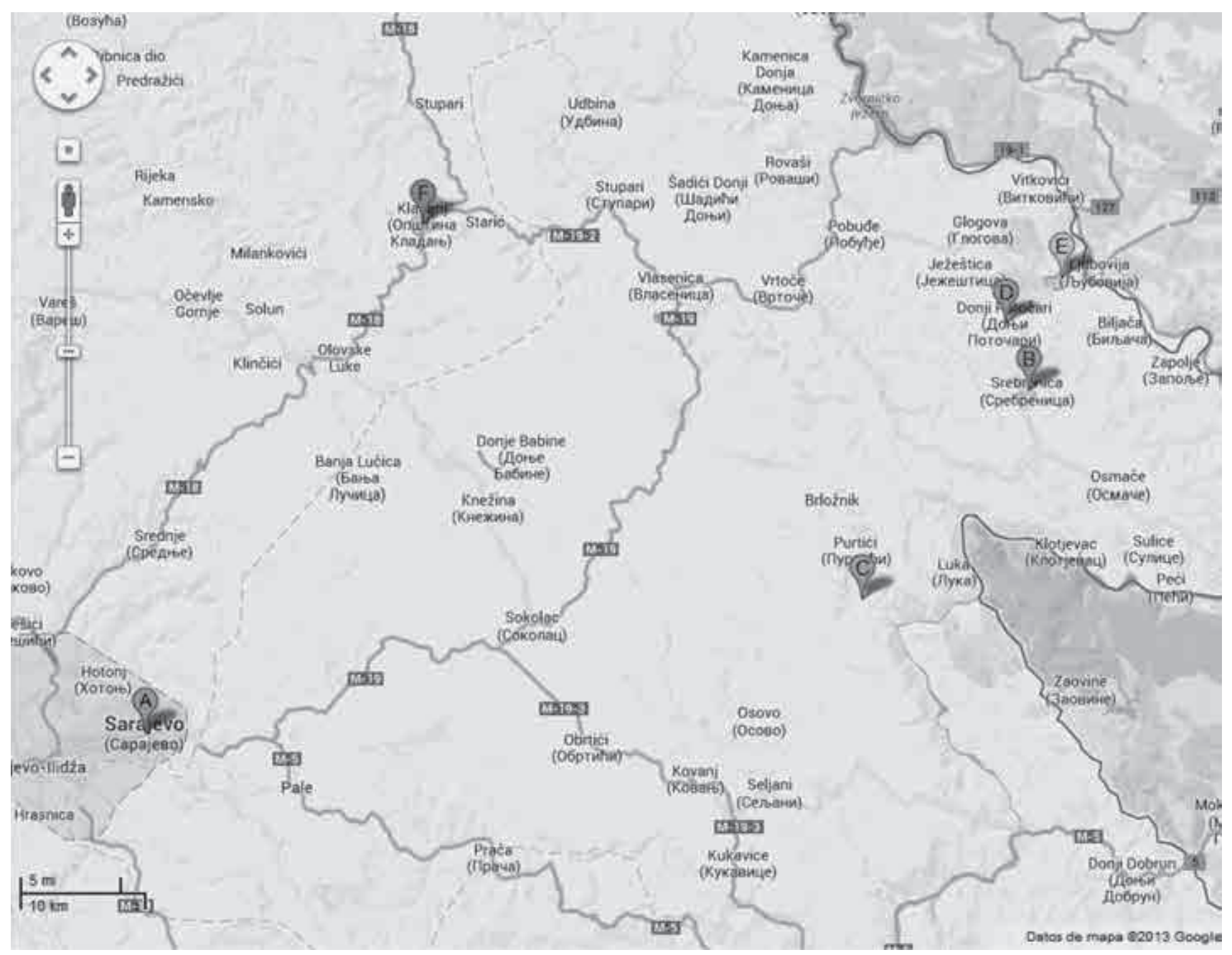

A: Sarajevo, Federación de Bosnia-Herzegovina, Bosnia-Herzegovina. B: Srebrenica, República de Sprska, Bosnia-Herzegovina. C: Zepa, República de Sprska, Bosnia-Herzegovina. D: Potocari, República de Sprska, Bosnia-Herzegovina. E: Bratunac, República de Sprska, Bosnia-Herzegovina. F: Kladanj, Federación de Bosnia-Herzegovina, Bosnia-Herzegovina.

* Modificaciones sobre el mapa de Google Maps.

Nota: La línea punteada marca el límite de lo que después sería a la fecha de estos hechos la Federación Bosnio-Herzegovino y la República de Sprska.

Entre 11 y el 12 de julio en la ciudad de Bratunac, en el Hotel Fontana se desarrolla una reunión entre el vRs, encabezado por Ratko Mladic, y el DutchBat, representado por el coronel Karremans, y representantes de los bosnio 
musulmanes. ${ }^{68}$ Karremans le informa a Mladic la situación humanitaria en que se encuentra Potocari ${ }^{69}$ y Mladic le responde que el objetivo de la operación era precisamente la evacuación de los bosnios musulmanes. ${ }^{70} \mathrm{La}$ situación del DutchBat era precaria con 20.000 refugiados alrededor de su complejo en graves condiciones humanitarias, ${ }^{71}$ por tanto, el 12 de julio a las 10 a.m. Mladic ofrece transportarlos, condicionando al DutchBat su colaboración con el combustible para los buses y la entrega de armamento de los bosnios-musulmanes, y estos aceptan, sin tener claridad completa de lo acordado. ${ }^{72}$ El 17 de julio, posteriormente a los hechos, llega el acuerdo por escrito donde señala que:

(1) que la población civil Bosnio Musulmana podría estar en el enclave o desalojarse, dependiendo de la voluntad de cada persona, (2) que la población civil Bosnio Musulmana puede ir a donde quiera si elige dejar el enclave, y que éstos habían elegido ser evacuados a Kladanj, y (3) que la evacuación estaría a cargo del vRs y de la po-

68 Cfr., tPiY, Sala de Primera Instancia, Prosecutor v. Popovic et al. Judgement (IT-05-88-T) del 10 junio de 2010, párr. 274; TPIY, Caso Prosecutor v. Tolimir, Zdravko. Judgement (IT-05-88/2-T) del 12 de diciembre de 2012, párr. 246; у тPIY, Caso Prosecutor v. Krstic, Radislav. Judgement (IT-98-33-T) del 2 de agosto de 2001, párr. 126.

69 Cfr., tPIY, Sala de Primera Instancia, Prosecutor v. Popovic et al. Judgement (IT-05-88-T) del 10 junio de 2010, párrs. 275, 277.

70 Cfr., ibíd., párr. 275.

71 Cfr., ibíd., párrs. 309-315.

72 Cfr., ibíd., párrs. 279, 291. 
licía de la Rs, con supervisión y acompañamiento de la UNPROFOR durante la evacuación. ${ }^{73}$

Sin embargo, con anterioridad al acuerdo del 12 de julio a las 10 a.m., desde el 11 de julio por la noche Mladic se comunica con el Ministerio de Defensa del Rs solicitando buses que serían utilizados para el transporte de los bosnios musulmanes, y el 12 de julio a las 7:35 a.m. Krstic solicita al teniente coronel Krsmanovic, jefe de transporte del Cuerpo Drina, 50 buses desde diferentes municipios. Tienen como punto de encuentro el estadio de los deportes en la ciudad de Bratunac, y de allí serán llevados a Potocari para la "evacuación”. ${ }^{4}$ Después Krstic se comunica con la Brigada Vlasenica, parte del Cuerpo Drina, para que estos se contacten con la policía de la Rs (MUP) para asegurar las rutas, por ejemplo removiendo minas y quitando barreras, para la evacuación hacia Kladanj, ciudad cercana al territorio del A.BiH. ${ }^{75}$ A pesar de que había acordado que el DutchBat daría el combustible, el vRs consiguió el combustible necesario para los buses y posteriormente se repone por parte

73 Ibíd., párr. 292.

74 Cfr., ibíd., párrs. 293, 294; TPIY, Caso Prosecutor v. Tolimir, Zdravko. Judgement (IT-05-88/2-T) del 12 de diciembre de 2012, párr. 270; y TPIY, Caso Prosecutor v. Krstic, Radislav. Judgement (IT-98-33-T) del 2 de agosto de 2001, párr. 138.

75 Cfr., tPiy, Sala de Primera Instancia, Prosecutor v. Popovic et al. Judgement (IT-05-88-T) del 10 junio de 2010, párr. 296; y TPIY, Caso Prosecutor v. Tolimir, Zdravko. Judgement (IT-05-88/2-T) del 12 de diciembre de 2012, párr. 274. 
del Batallón. ${ }^{76}$ Este mismo día por la mañana las unidades especiales del mup y la Brigada Bratunac (también del Cuerpo Drina), obtienen el control de Potocari. Después hacen una búsqueda exhaustiva de los refugiados alrededor del complejo del DutchBat con perros e incendiando casas. ${ }^{77}$

Finalmente, en lo que nos concierne, en la tarde del 12 de julio empiezan a llegar los buses al complejo del DutchBat ${ }^{78}$. Mladic da la orden de evacuar a todos los bosnios musulmanes, a pesar de lo que se había acordado. ${ }^{79}$ Antes de movilizarlos, la Policía Militar de la Brigada Bratunac separa los hombres, entre las edades de 15 a 65 años, de sus familias. ${ }^{80}$ Las mujeres, niños y ancianos son llevados Klandaj, mientras que los hombres fueron llevados a la ciudad de Bratunac. ${ }^{81}$ El transporte y la separación de los bosnio musulmanes continuó hasta el día siguiente, principalmente para los que estaban heridos. ${ }^{82}$ Estos hechos constituyen un desplazamiento forzado de la población bosnio-musulmana.

76 Cfr., tPIY, Sala de Primera Instancia, Prosecutor v. Popovic et al. Judgement (IT-05-88-T) del 10 junio de 2010, párrs. 297, 301; y TPIY, Caso Prosecutor v. Tolimir, Zdravko. Judgement (IT-05-88/2-T) del 12 de diciembre de 2012, párr. 271.

77 Cfr., tPiy, Sala de Primera Instancia, Prosecutor v. Popovic et al. Judgement (IT-05-88-T) del 10 junio de 2010, párrs. 302, 303, 305.

78 Ibíd., párr. 316.

79 Ibíd., pár. 318; Cfr., TPIY, Caso Prosecutor v. Tolimir, Zdravko. Judgement (IT-05-88/2-T) del 12 de diciembre de 2012, párr. 276; y TPIY, Caso Prosecutor v. Krstic, Radislav. Judgement (IT-98-33-T) del 2 de agosto de 2001, párr. 147.

80 Cfr., tpiY, Sala de Primera Instancia, Prosecutor v. Popovic et al. Judgement (IT-05-88-T) del 10 junio de 2010, párr. 319.

81 Ibíd., párrs. 332, 338.

82 Ibíd., Párrs. 323, 341. 


\subsubsection{Apreciaciones del Tribunal}

\section{sobre las interceptaciones de comunicaciones}

Esta reconstrucción del desplazamiento forzado de Srebrenica, si bien pareciera ser un caso con mayor detalle que con respecto a los tres casos nacionales anteriormente expuestos, son en realidad tres casos de TPIY sobre los mismos hechos, pero las personas a las que se acusa son diferentes; estos casos son Popovic et al, Tolimir y Krstic. Aquí vale la pena señalar que no se puede entender el alcance de una prueba sin comprender su contexto.

Las interceptaciones que hizo el A.вiH. al vRs fueron aportadas a la Fiscalía ante el TPIY por el gobierno bosnio. Ante esto la Fiscalía constituyó un grupo llamado "proyecto interceptación" (Intercept Project), que tiene por fin analizar, investigar y traducir las interceptaciones que se hayan obtenido por los diferentes sujetos del conflicto. Ahora, en el caso de las interceptaciones que hicieron los bosnios musulmanes, si bien no tenían el mejor nivel para ello, al cruzar la información con las pruebas obtenidas se encuentran coincidencias. ${ }^{83}$ Este procedimiento, para el Tribunal, le da suficiente fiabilidad al material probatorio, teniendo en cuenta no solo la forma en que se obtuvo la información, sino además el cuidado contra la ruptura de la cadena de custodia. ${ }^{84}$

83 Cfr., ibíd., párrs. 105, 107, 114; y TPIY, Caso Prosecutor v. Krstic, Radislav. Judgement (IT-98-33-T) del 2 de agosto de 2001, párrs. 105, 106.

84 Cfr., tpir, Sala de Primera Instancia, Prosecutor v. Popovic et al. Judgement (IT-05-88-T) del 10 junio de 2010, párrs. 64, 116; TPIY, Caso Prosecutor v. Tolimir, Zdravko. Judgement (IT-05-88/2-T) del 12 de diciembre de 2012, párrs. 
De este resumido relato encontramos que las interceptaciones de comunicaciones sirvieron para probar cómo se movilizaron y se obtuvieron los buses, la seguridad de las rutas durante la evacuación por parte de la policía, la obtención del combustible y la orden de desplazar a todos los bosnios musulmanes a pesar del acuerdo. ${ }^{85}$ Acorde con ello, en los tres casos expuestos fueron condenados por el crimen de desplazamiento forzado y por otras conductas relacionadas con este, y también por el crimen de genocidio, entre otros. ${ }^{86}$ En los casos Popovic et al. y Tolimir, se intentó excluir las interceptaciones: en el primer caso porque no resultaban fiables; y en el segundo, por la forma como se introdujo al proceso. Sin embargo, en ninguno de estos prosperó la petición de la defensa y se admitieron las interceptaciones, puesto que las salas consideraron que en efecto sí eran fiables y la introducción de estas al proceso estaban en regla. ${ }^{87}$

65, 66; у тріу, Caso Prosecutor v. Krstic, Radislav. Judgement (IT-98-33-T) del 2 de agosto de 2001, párrs. 105-117.

85 Cfr., tPiy, Sala de Primera Instancia, Prosecutor v. Popovic et al. Judgement (IT-05-88-T) del 10 junio de 2010, párrs. 294, 286, 297, 318; TPIY, Caso Prosecutor v. Tolimir, Zdravko. Judgement (IT-05-88/2-T) del 12 de diciembre de 2012, párrs. 270, 271, 274, 276; y тPIY, Caso Prosecutor v. Krstic, Radislav. Judgement (IT-98-33-T) del 2 de agosto de 2001, parrs. 138, 147.

86 Cfr., TPIY, Sala de Primera Instancia, Prosecutor v. Popovic et al. Judgement (IT-05-88-T) del 10 junio de 2010, Apartado IX; TPIY, Caso Prosecutor v. Tolimir, Zdravko. Judgement (IT-05-88/2-T) del 12 de diciembre de 2012, párr. 1239; y тPIY, Caso Prosecutor v. Krstic, Radislav. Judgement (IT-98-33-T) del 2 de agosto de 2001, párr. 727.

87 TPIY, Sala de Primera Instancia, Caso Prosecutor v. Popovic et al. "Decisión on Admisibility of intercepted communication" (IT-05-88-T) del 7 de 
Es imperativo resaltar que todas las interceptaciones aportadas fueron hechas a las comunicaciones de la misma parte del conflicto armado. Por otra parte, si bien los que interceptaron también son sujetos activos, el análisis está más enfocado a la fiabilidad de los documentos aportados a la Fiscalía. De esta manera vemos que, a pesar de que el Tribunal no lo dice expresamente, se cumple el principio de distinción que ordena el DIH, como también lo establecido en la doctrina Schenck por la CEDH con respecto a garantizar la autenticidad de la prueba y la garantía de poder contradecir la prueba, excluyendo la remisión a los sistemas judiciales domésticos.

\section{Conclusiones: aplicación a los tres casos}

El TPIY, cuya jurisprudencia nos ayuda a interpretar el ER, toma la postura del caso Schenck, partiendo de la base de que la interceptación por sí misma no perjudica el juicio; si bien a la luz de la Corte Europea puede llegar a vulnerar el derecho a la privacidad, no es suficiente para alegar su exclusión ante la TPIY y la CPI. Sin embargo, como se expuso en el caso Lubanga, encontramos que se excluye la remisión al derecho doméstico, puesto que el referente que se debe estudiar es si hace algún perjuicio al Estatuto o a alguna normatividad internacional. En estos casos, generalmente se busca la exclusión probatoria a partir de alegar su no

diciembre de 2007, párrs. 46, 54, 66-77; y Cfr., TPIY, Sala de Primera instancia, Caso Prosecutor v. Tolimir, Zdravko. "Decision on prosecution's motion for admission of 28 intercepts from the bar table" (IT-05-88/2-T) de 20 de enero de 2012, párr. 15. 
autenticidad, situación diferente a un estado de coacción, o cuando se vulnera el derecho a la defensa, en los que la regla de exclusión sí prospera porque tiene un relación directa con el derecho a la defensa, como sucede en el caso Celebici, y la prohibición de uso de la prueba producida por tortura o cualquier forma de coacción, como se presenta en el caso Martic.

Por lo anterior, encontramos que el estándar de prueba de la regla de exclusión en la CPI es diferente a la regla de exclusión en el derecho colombiano. En la CPI, en el estudio de la exclusión si bien se observa si hubo una violación de un derecho humano, se condiciona adicionalmente que la prueba sea fiable, o que haya un perjuicio al estatuto o al proceso judicial. Lo que desarrolló la CEDH se puede ver en dos puntos: primero, se deben garantizar la autenticidad y la contradicción de la prueba; segundo, que la revisión de cumplimiento de las garantías judiciales debe hacerse en conjunto con los procedimientos legales que establecen los sistemas nacionales, lo que obliga a que haya una remisión al derecho interno. En nuestro caso, la regla de exclusión, como nosotros la entendemos, hace parte de las garantías judiciales domésticas. Sin embargo, el TPIY, solamente tomó la posición de la CEDH de revisar la autenticidad de la prueba y garantizar el principio de contradicción, sin revisar el cumplimiento de las garantías judiciales domésticas. La CPI, de acuerdo con su sistema de fuentes previsto en el art. 21 del ER, tomó la posición del TPIY.

De igual forma, el método que usó la Fiscalía ante la TPIY para confirmar la fiabilidad de la prueba fue revisar 
cada prueba de manera individual, y además hacer el estudio en conjunto de todas las pruebas. De tal manera que este requisito se debe estudiar desde los dos puntos de vista, de manera individual, y de manera conjunta, lo que no es novedad para el derecho colombiano, en cumplimiento del principio de unidad de la prueba.

Es importante señalar que al estudiar el caso del desplazamiento forzado de Srebrenica encontramos el cumplimiento del principio de distinción del DIH, puesto que todos los miembros a quienes se les interceptaron comunicaciones eran miembros activos del conflicto, así como también lo eran aquellos que interceptaron.

Si aplicamos esta regla de exclusión a nuestros tres casos, encontramos que en el primero el resultado puede ser diferente, y en los otros dos, la argumentación de la no exclusión puede variar:

1. En el caso de Juan Carlos Castillo, vemos que la autenticidad de la prueba se satisface puesto que la interceptación se hizo por parte de miembros de la inteligencia del Ejército Nacional, y como se pudo contradecir en primera instancia, la prueba no sería excluida.

2. En el caso de la masacre de Macayepo, se confirma la posición de la Corte Suprema de Justicia, y se deja de lado el debate de si la actividad que tuvo la sipol puede tener uso judicial. Sin embargo, aquí termina siendo sumamente importante la forma en que se puede adelantar la contradicción de la prueba, puesto 
que si no se logra debatir los métodos de cómo se obtuvo la información, se restringe el principio de contradicción de la prueba. La regla que plantea la Corte Constitucional de que la prueba producida en función de una orden judicial previa no se cumpliría en este caso, por lo que bastaría con revisar la autenticidad y contradicción de la prueba.

3. En el caso de la toma al Palacio de Justicia, la investigación se debe enfocar en si la capacidad que tenían las personas particulares que no tenían una participación directa en el conflicto satisface los requerimientos técnicos para garantizar la fiabilidad de la prueba. Sin embargo, también se puede aducir su fiabilidad a partir del cruce de información entre las diferentes grabaciones; cuando estas son concordantes, se puede decir que fueron auténticas, y por tanto tienen valor probatorio, siendo relevantes para el proceso. En este caso, la contradicción en que entra el Tribunal Superior de Bogotá con la regla general que estableció la Corte Constitucional, con respecto a si hubo o no una violación al derecho a la intimidad, no es relevante para esta regla de exclusión puesto que se pudo contradecir la prueba durante el proceso judicial. 


\section{Conclusiones generales}

El Estado colombiano invoca el respeto y la protección a la dignidad humana, y esta se manifiesta en conjunto con otros derechos fundamentales, como es el derecho a la intimidad, a partir del cual la persona puede tener la tranquilidad de manifestar su propia voluntad sin ningún tipo de injerencia. Sin embargo, el Estado también tiene el deber de perseguir las conductas delictivas, y por ello en algunos casos resulta necesario hacer injerencias en la privacidad de las personas, como por medio de la interceptación de comunicaciones.

Si bien la regla general es que no se pueda realizar ningún tipo de injerencia, la excepción consiste en que, si resulta necesario, la Fiscalía podrá ordenar que se adelante la interceptación de comunicaciones, como un rezago de sus funciones jurisdiccionales según el art. 250 constitucional, y después deberá surtir el control posterior del juez de control de garantías. Esta excepción está regulada por la ley; en el supuesto de que no se cumpla con lo regulado, el material probatorio resultante deberá ser excluido del proceso judicial, puesto que la regla de exclusión es una garantía procesal para la protección de los derechos humanos que condiciona la producción probatoria y su uso judicial, aplicable en cualquier momento y a través de los diferentes recursos y mecanismos legales y constitucionales. 
A pesar de que esto pareciera ser suficientemente claro, vemos que algunas actividades, que originalmente no están encaminadas a que produzcan efectos directos en un proceso judicial, como es el caso de las actividades de inteligencia y contrainteligencia, producen información que puede terminar siendo aportada al proceso penal como un elemento probatorio para demostrar la responsabilidad penal de quien se esté acusando. Si bien esta actividad está regulada por la Ley Estatutaria 1621 de 2013, el cPP vigente no tiene una regulación para que estas actividades deban ser tenidas en cuenta, a diferencia de los Códigos anteriores (principalmente el Decreto 2700 de 1991). Sin embargo, la Corte Constitucional, en la Sentencia C-392 de 2000 hizo un aporte en esta materia cuando revisó la constitucionalidad del art. 313 del Decreto 2700, en el sentido de que estas pruebas no podrán ser tenidas en cuenta a menos que se garantice a la defensa la posibilidad de contradecirlas.

Pero si la regla general de la Corte Constitucional, que se ha reiterado en varias sentencias, es que ninguna persona, pública o privada, por más loable que sea la razón, está autorizada para adelantar injerencias en las comunicaciones a menos que exista orden judicial y específica para hacerlo, entra en contradicción con el uso del material de las entidades de inteligencia, o incluso con la información aportada por personas particulares. Esto se ve por ejemplo en el caso del exmilitar Juan Carlos Castillo, quien le vendía armamento a las FARC, autodefensas y bandas criminales, donde si bien se aportaron interceptaciones por parte de la RIME 4 a la Fiscalía, y luego se excluyeron durante el proceso, el cTi las 
tuvo en cuenta para la dirección de su investigación, en este caso, el Tribunal de Bogotá consideró que había un vínculo atenuado entre las investigaciones del CTI y las interceptaciones de la RIME 4, las que terminan llegando a un mismo punto. Situación diferente al caso de la masacre de Macayepo en cuanto que las captaciones incidentales aportadas por la SIPOL sirvieron para demostrar la responsabilidad penal de García Romero y Morris Taboada. En este caso la Corte Suprema de Justicia consideró que se dio la oportunidad de contradecir la prueba y por tanto no fue objeto de exclusión; sin embargo, queda en contradicción con la regla general de la Corte Constitucional. En la toma al Palacio de Justicia, encontramos que las grabaciones que se aportaron al proceso fueron hechas por personas particulares, $y$ fueron útiles para demostrar la responsabilidad penal del coronel (r) Alfonso Plazas Vega; en este caso, el Tribunal de Bogotá, sala mayoritaria, considera que la prueba es confiable y lícita, a diferencia de lo que se plantea en el salvamento de voto.

Es palpable la contradicción que hay entre la regla general y los tres casos expuestos. Sin embargo, es importante resaltar que entre los tres casos hay un factor en común: que los tres tienen relación con el conflicto armado interno. Esta contradicción nos lleva a revisar cómo se ha venido tratando en otros espacios. Así llegamos al DIH, que es la normatividad especial para estos contextos. En él no encontramos una prohibición expresa de la interceptación de comunicaciones, o en general a las injerencias en las comunicaciones, pero sí una regla que permite emplear las medidas necesarias para obtener información del enemigo. 
A pesar de ello, la regulación que trae el DIH está enfocada a los conflictos armados internacionales, no con respecto a los no internacionales; por ello resulta importante revisar lo regulado por el DIDH, puesto que en estas situaciones ambos derechos terminan complementándose. El punto de contacto entre el uno y el otro, que en cualquier caso se protegerá las garantías judiciales, en el caso del DIH lo encontramos en el art. 3 común a los cuatro convenios de Ginebra, y en el DIDH lo encontramos en la prohibición de suspensión de garantías judiciales en el art. 27.2 de la CADH junto con lo que ha venido desarrollando el Comité de Derechos Humanos en la Observación General n. ${ }^{\circ} 2$.

En relación con la exclusión probatoria, su principal desarrollo la encontramos en la CEDH. Esta ha venido desarrollando una postura, originalmente en los casos Malone y Schenck, ambos contra el Reino Unido, según la cual si bien las interceptaciones cometidas fueron violatorias del derecho a la intimidad, la prueba no se excluye del proceso en cuanto pudo estar sometida a contradicción por parte de la defensa, y por ello no se vulneran las garantías judiciales reconocidas en la Convención Europea de Derechos $\mathrm{Hu}-$ manos. A partir de estos dos casos, se exige desde este foro internacional si la prueba resulta auténtica o si la prueba se pudo contradecir durante el proceso judicial; a pesar de ello, la CEDH vincula el cumplimiento de la normatividad doméstica, como cumplimiento del principio de legalidad de cada sistema jurídico interno, en consonancia con la Observación General n. ${ }^{\circ} 16$ del Comité. Esta postura, por la remisión que se hace a los sistemas nacionales, no produce 
mayores cambios para Colombia, pues nosotros tenemos la regla de exclusión como parte del proceso judicial. Este sistema no ofrece, entonces, solución para las contradicciones propuestas en nuestros casos.

Al consultar el TPIY encontramos que la regla de exclusión está encaminada a la exclusión de pruebas no fiables, y de aquellas que pueden ir en perjuicio del mismo Estatuto. Si bien es cierto que el tema de la fiabilidad se relaciona con la autenticidad de la prueba, el TPIY toma una parte de lo que se ha adelantado en la doctrina Schenck, y de allí se proyecta a la CPI. De igual forma, considera que la prueba se debe poder contradecir, como parte de las garantías judiciales del proceso. Adicionalmente, el TPIY agrega que las violaciones en general al derecho a la defensa - como la declaración sin abogado y rendir testimonio bajo situación de cualquier tipo de coacción - generarían su exclusión.

A pesar de estos puntos comunes sobre el respeto a las garantías judiciales, que son trasversales al DIH, al DIDH y al DIP, encontramos que hay una diferencia importante: mientras la doctrina Schenck requiere el cumplimiento del principio de legalidad según la normatividad interna, tanto el TPIY en sus RPP como la CPI en el ER consideran que se debe ajustar a su propia normatividad, mas no el sistema jurídico doméstico. Esto hace que el art. 23 del CPP y el inc. 5 del art. 29 constitucional -donde se reconoce la regla de exclusión - no podrán ser aplicados en los procesos judiciales que se adelanten ante estos foros internacionales. Básicamente, la diferencia radica en que el principio de legalidad por el cual se obliga a sistemas de derechos humanos a 
revisar los sistemas nacionales, en el caso de la CPI y el TPIY se atiene a su propia normativa, sin importar las reglas domésticas, como sucedió en el caso Lubanga. Sin embargo, es importante señalar que la CPI, a diferencia de la TPIY, hace un ejercicio de ponderación entre la impunidad a partir de la exclusión probatoria y los derechos del acusado, teniendo como referente su propia normatividad, para hacer el análisis de proporcionalidad.

La regla de exclusión que trae consigo la CPI es diferente a la nuestra, y su aplicación a los tres casos que hemos propuesto terminarían con respuestas diferentes: en el caso de Juan Carlos Castillo, las pruebas no resultarían excluidas porque se satisface la autenticidad y la posibilidad de contradicción. En el caso de la masacre de Macayepo, la obligación de que las injerencias en las comunicaciones partan de una orden judicial no se tendría en cuenta, por lo que la Corte Suprema podría haber justificado la admisión de las injerencias a pesar de la regla constitucional interna existente. Finalmente, en el caso de la toma del Palacio de Justicia, las grabaciones que hayan hecho los particulares tendrían que estudiarse de manera conjunta para corroborar su autenticidad, pero tan pronto se supere este punto, la contradicción entre las posiciones de la Corte Constitucional y el Tribunal Superior de Bogotá termina pasando a un segundo plano, haciendo que las grabaciones sean prueba admisible porque se comprobó su fiabilidad.

La Corte Constitucional en la Sentencia C-578 del 30 de julio de 2002, donde hace el análisis constitucional del ER, sobre la regla de exclusión dice lo siguiente: 
De este modo, todas las pruebas obtenidas como resultado de una violación del Estatuto o de las normas de derechos humanos internacionalmente reconocidas serán inadmisibles (regla de exclusión) cuando la violación suscite serias dudas sobre la fiabilidad de las pruebas o cuando su admisión atente 'contra la integridad del juicio o redunde en grave desmedro de él'. Estas disposiciones coinciden con los principios establecidos en la Constitución colombiana, que también protegen la integridad del acervo probatorio y consagran la nulidad de las pruebas obtenidas con violación del debido proceso. ${ }^{1}$

Esto se estudió para el año de 2002, pero después se implementó el sistema penal acusatorio, a partir del Acto Legislativo 03 de 2002 y la Ley 906 de 2004. Como principal sentencia que analiza la regla de exclusión dentro de este sistema se tiene la C-591 de 2005, la cual, si bien termina por reafirmar la regla de exclusión expuesta en la Sentencia su159 de 2002, al admitir las llamadas excepciones de exclusión de la prueba derivada, no la analiza desde los elementos que trata el art. 69.7 del ER.

La Sentencia C-578 de 2002 establece algunos tratamientos diferentes solo aplicables en el marco de la CPI, y no consideró la regla de exclusión del ER como uno de estos. Sin embargo, entre las dos reglas de exclusión, la del art. 23 de CPP y art. 29 constitucional, por una parte, y el art. 69.7 del ER, por otra, hay claras diferencias, a pesar de lo

1 Corte Constitucional, Sentencia C-578 de 2002. 
que interpretó la Corte en ese momento, y con base en esas diferencias se llega a conclusiones contradictorias, como en los casos propuestos.

\section{Tareas pendientes}

Al estudiar los diferentes cambios que ha tenido el proceso penal, encontramos los rezagos que mantienen a la Fiscalía como entidad jurisdiccional que puede adelantar una interceptación de comunicaciones sin control previo por un juez. Sin embargo, en el anterior sistema la Fiscalía tenía un control previo, a pesar de que fuera dentro de la misma entidad, y si esto era garantizado en el Decreto 2700 de 1991 y la Ley 600 de 2000, en concordancia con el Estatuto Orgánico de la Fiscalía, Decreto 2699 de 1991, con mayor razón debería ser así en la Ley 906 de 2004; sin embargo, este control previo fue omitido dentro de la Ley 938 de 2004, Estatuto Orgánico vigente. Por tanto, se debería estudiar la viabilidad de adelantar una acción pública de inconstitucionalidad por omisión legislativa por este asunto.

Finalmente, también habría que adelantar una acción pública de inconstitucionalidad contra el art. 69.7 del ER puesto que si bien la Corte Constitucional lo trató en su momento, el sistema jurídico ha tenido cambios considerables. Dicha demanda estaría encaminada a que la Corte tomara la posición anteriormente expuesta, o que considere que este debe ser sujeto de un tratamiento diferencial, donde si bien pareciera ser cosa juzgada, se presentaría alegando "derecho vivo". Aun así, es importante reflexionar sobre la ponderación que hace la CPI, entre la impunidad de hechos 
concretos, a partir de la exclusión de medios probatorios, y los derechos del procesado, pero esta tendrá que ser a partir de nuestras propias formas jurídicas. 



\section{Referencias}

\section{Artículos}

Chetail, Vincent. The contribution of the International Court of Justice to international humanitarian law. International Review Red Cross (Vol. 85) (n. ${ }^{\circ} 850$ ), junio-2003.

Daza González, Alfonso. Evidencia ilegal, evidencia ilícita y regla de exclusión. En: Revista Derecho Penal Contemporáneo (n. $\left.{ }^{\circ} 27\right)$. ISSN: 1692-168. Editorial Legis, Bogotá (abril-junio), 2009.

Abello Galvis, Ricardo. Introducción al estudio de las normas de ius cogens en el seno de la comisión de derecho internacional, CDI. En: Vniversitas, Pontificia Universidad Javeriana-Facultad de Ciencias Jurídicas (n. ${ }^{\circ} 123$ ) IssN: 0041-9060. Bogotá (julio-diciembre), 2011.

\section{Libros}

Asimov, Issac. Cronología del mundo. La historia del mundo desde el Big Bang a los tiempos modernos. Arial Ciencia, Barcelona, 1992.

Armenta Deu, Teresa. La prueba ilícita (un estudio comparado). 2. ${ }^{a}$ ed., Edit. Marcial Pons, Madrid, 2009.

Beling, Ernst. Las probibiciones de prueba como límite a la averiguación de la verdad en el proceso penal. En: Beling, 
Ernst y otros. Las probibiciones probatorias. Editorial Temis S.A., Bogotá, 2009.

Buisman, Caroline. Evidence before International Criminal Courts and Tribunals. En: Bantekas, Ilias International

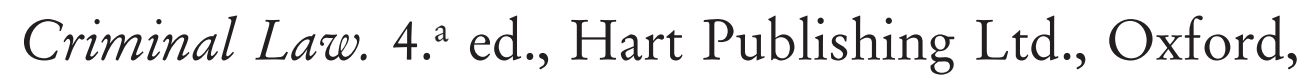
2010.

Cherif Bassiouni, Mahmoud. Introduction to International Criminal Law. 2. ${ }^{a}$ ed., revisada. Editorial Martinus Nijhoff Publishers, Leiden, 2013.

Cherif Bassiouni, Mahmoud. Issues Pertaining to the Evidentiary Part of International Criminal Law. En: Cherif Bassiouni, Mahmoud (Edit.). International Criminal Law. 3. ${ }^{a}$ ed., Martinus Nijhoff Publishers, Leiden, 2008.

Diccionario de la Real Academia de la Lengua Española. Versión digital, consultado en: http://lema.rae.es/drae/ Escobar López, Édgar y Marulanda Otálvaro, Luz Fabiola. El derecho a la intimidad.2. ${ }^{a}$ ed., Ediciones Doctrina y Ley, Bogotá, 2004.

Farfán Molina, Francisco. La interceptación de comunicaciones telefónicas en el proceso penal y disciplinario. Ediciones Nueva Jurídica, Bogotá, 2008.

Fierro Méndez, Heliodoro. Prueba ilícita. Interceptación de comunicaciones y registro de computadores. Ediciones Doctrina y Ley, Bogotá, 2012.

Fiscalía General de la Nación. Manual de procedimientos de la Fiscalía en el sistema penal acusatorio. Fiscalía General de la Nación, Bogotá, 2009. 
Guerrero Peralta, Óscar Julián. Institutos probatorios del nuevo proceso penal. 1. ${ }^{a}$ ed., Ediciones Nueva Jurídica, Bogotá, 2009.

Guerrero Peralta, Óscar Julián. Las probibiciones de prueba en el proceso penal colombiano. Anotaciones desde el derecho comparado. En: Beling, Ernst y otros. Las probibiciones probatorias. Editorial Temis S.A., Bogotá, 2009, pp.155, 156.

Hernández Hoyos, Diana. Derecho internacional humanitario.

3. ${ }^{a}$ ed., Ediciones Nueva Jurídica, Bogotá, 2012.

Klamberg, Mark. Evidence in international criminal Trials. Confronting lagal Gaps and the Reconstruction of Disputed Events. Editorial Martinus Nijhoff Publishers, Leiden, 2013.

Moir, Lindsay. The Law of Internal Armed Conflict. University of Cambridge, Cambridge, 2002.

Montealegre Lynett, Eduardo; Bernal Cuéllar, Jaime El proceso penal. Estructura y garantías procesales. Tomo II. Sexta edición. Universidad Externado de Colombia, Bogotá, 2013.

Novoa Velásquez, Néstor Armando. Nulidades en el procedimiento penal. Actos procesales y acto prueba. Sistemas mixto inquisitivo y mixto acusatorio. Tomos I y II. Editorial Biblioteca Jurídica Diké, Bogotá, 2011.

Olásolo Alonso, Héctor. Corte Penal Internacional. ¿Dónde investigar? Especial referencia a la Fiscalía en el Proceso de Activación. Editorial Tirant lo Blanch, Cruz Roja Española. Valencia, 2002. 
Olásolo Alonso, Héctor. Admisibilidad de situaciones y casos objeto de procesos de justicia de transición ante la Corte Penal Internacional. En: Ensayos de derecho penal y procesal internacional. Con inclusión de la lección inangural de la Universidad de Utrecht (Holanda) dictada el 18 de octubre de 2010. Biblioteca Jurídica Diké, Instituto Iberoamericano de la Haya, Unión Europea, República de Colombia-Ministerio de Justicia y del Derecho. Bogotá, 2011.

Parra Quijano, Jairo. Manual de derecho probatorio. 17. a ed., Librería ediciones el profesional, Bogotá, 2009.

Pictet, Jean. Desarrollo y principios del derecho internacional bumanitario. Curso dado el mes de julio de 1982 en la Universidad de Estrasburgo en el marco de la Reunión de Enseñanza organizada por el Instituto Internacional de Derechos Humanos. Instituto Henry Dunant, Comité Internacional de la Cruz Roja. 3. ${ }^{a}$ reimpresión, Gráficas Ducal Ltda., San José de Costa Rica, 2001.

Quinche Ramírez, Manuel Fernando. Derecho Constitucional Colombiano: de la Carta de 1991 y sus reformas. 5. ${ }^{a}$ ed., Editorial Temis, Bogotá, 2008.

Quispe Remón, Florabel. El debido proceso en el derecho internacional y en el sistema interamericano. Editorial. Tirant lo Blanch, Valencia, 2010.

Ramírez Contreras, Luis Fernando. Las audiencias en el sistema

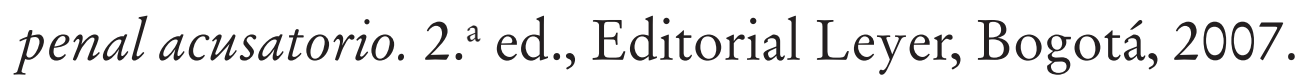
Rojas Gómez, Manuel Enrique. Eficacia de la prueba obtenida mediante irrupción en la intimidad. Universidad Externado de Colombia, Bogotá, 2011. 
Salmón, Elizabeth. Introducción al derecho internacional bumanitario. Fondo Editorial de la Pontificia Universidad Católica de Lima-Comité Internacional de la Cruz Roja, Lima, 2004.

Schabas, William A. The International Criminal Court: Comentary on the Rome Statute. Oxford University Press, Oxford, 2010.

Schabas, William A. The UN International Criminal Tribunals. The former Yugoslavia, Rwanda and Sierra Leona. Cambridge University Press, New York, 2006.

Swinarski, Christophe. Principales nociones e institutos del derecho internacional humanitario como sistema de protección de la persona. 2. ${ }^{a}$ ed., Instituto Interamericano de Derechos Humanos, San José, 1991.

Thürer, Daniel. International Humanitarian Law: Theory, Practice, Context. Hague Academy of International Law, Haya, 2011.

Urbano Martínez, José Joaquín. Prueba ilícita y regla de exclusión. En: Uprimny, Rodrigo y otros. Reflexiones sobre el nuevo sistema procesal penal. Instituto de Estudios del Ministerio Público. 2. ${ }^{a}$ ed., Bogotá, 2006.

Uribe Alarcón, María Victoria. Salvo el poder, todo es ilusión. Mitos de origen: Tigres Tamiles de Sri Lanka, Fuerzas Armadas de Colombia, Irish Rupublican Army. Instituto Pensar, Universidad Pontifica Javeriana, Bogotá, 2007. Von Clausewitz, Carl. De la guerra. Edit. La Esfera de los Libros. Versión íntegra. Madrid, 2005.

Von Hirsh, Andrew. El concepto de bien jurídico y el "principio de daño". En: Hefendehl, Roland (Edit.) La teoría del 
bien jurídico. ¿Fundamento de legitimación de derecho penal o juego de abolorios dogmático? Editorial Marcial Pons, Madrid, 2007.

Zagrebelsky, Gustavo. El derecho dúctil. Ley, derechos y justicia. 10. ${ }^{a}$ ed., Editorial Trotta, Madrid, 2011.

\section{Documentos internacionales}

Corte Penal Internacional, Asamblea de los Estados Partes.

Reglas de Procedimiento y Prueba. ICC-ASP/1/3 (Part. II-A) de 9 de septiembre de 2002.

Naciones Unidas, Recopilación de las observaciones generales y recomendaciones generales adoptadas por órganos creados en virtud de tratados de derechos humanos. HRI/ GEN/1/Rev.9 (Vol. I) de 27 de mayo de 2008.

Naciones Unidas, Asamblea General. Informe del Comité de Derechos Humanos, Cuadragésimo tercer periodo de sesiones suplemento n. ${ }^{\circ} 40$ (A/43/40) de 28 de septiembre de 1988.

Naciones Unidas, Comité de Derechos Humanos. Observación General n. ${ }^{\circ}$ 16, Article 17 (The right to respect of privacy, family, home and correspondence, and protection of honour and reputation) HRI/GEN/1/Rev.7 at $162 \mathrm{de}$ 28 de septiembre de 1988.

Naciones Unidas, Comité de Derechos Humanos. Observación General n. 29 Artículo 4 (Estados de emergencia) CCPR/C/21/Rev.1/Add.11 del 31 agosto de 2001.

Naciones Unidas, Consejo Económico y Social-Comisión de Derechos Humanos. Informe de la Subcomisión de prevención de discriminaciones y protección a las mi- 
norías sobre su $46^{\circ}$ periodo de sesiones-Declaración de Normas Humanitarias Minimas (Normas de Turku) E/ CN.4/1995/116 de 31 de enero de 1995.

Naciones Unidas, International Tribunal for the Prosecution of Persons Responsible for Serious Violations of International Humanitarian Law Committed in the Territory of the former Yugoslavia since 1991 (Tribunal Penal Internacional para la ex-Yugoslavia). Rules of procedure and evidence (IT/32/Rev. 49) de 22 de mayo de 2013.

\section{Legislación nacional}

Constitución Política de Colombia, publicada en la Gaceta Constitucional n. ${ }^{\circ} 116$ de 20 de julio de 1991.

Congreso de la República. Acto Legislativo 03 de 2002. Por medio del cual se modifican los artículos 15, 24, 28 y 250 de la Constitución Política de Colombia para enfrentar el terrorismo, publicado en el Diario Oficial n. ${ }^{\circ} 45.406$, de 19 de diciembre de 2003.

Congreso de la República, Ley 906 de 2004. Por la cual se expide el Código de Procedimiento Penal, publicada en el Diario Oficial n. ${ }^{\circ} 45.658$ de $1^{\circ}$ de septiembre de 2004.

Congreso de la República. Ley 1621 de 2013. Por medio de la cual se expiden normas para fortalecer el Marco Jurídico que permite a los organismos que llevan a cabo actividades de inteligencia y contrainteligencia cumplir con su misión constitucional y legal, y se dictan otras disposiciones, publicada en el Diario Oficial n. ${ }^{\circ} 48.764$ de 17 de abril de 2013. 


\section{Instrumentos internacionales}

Conferencia Diplomática de Plenipotenciarios de las Naciones Unidas. Estatuto de la Corte Penal Internacional. Adoptada en Roma el 17 de julio de 1998.

Conferencia Diplomática para Elaborar Convenios Internacionales destinados a proteger las víctimas de la Guerra. Artículo 3 común a los cuatro Convenios de Ginebra. Tomado de III Convenio de Ginebra del 12 de agosto de 1949 relativo al trato debido a los prisioneros de guerra. Aprobado el 12 de agosto de 1949.

Conferencia Interamericana de Derechos Humanos. Convención Americana de Derechos Humanos. Adoptada el 22 de noviembre de 1969. Entrada en vigor el 18 de julio de 1978.

Consejo de Europa. Convenio para la Protección de los Derechos Humanos y de las Libertades Fundamentales (Convenio Europeo de Derechos Humanos). Adoptado el 4 de noviembre de 1950.

Naciones Unidas. Asamblea General. Pacto Internacional de Derechos Civiles y Politicos. Adoptada en su Resolución 2200 A (XXI) de 16 de diciembre de 1966.

Segunda Conferencia de Paz de la Haya. Reglamento concerniente a las leyes y costumbres de la guerra terrestre. Anexo al Convenio IV relativo a las leyes y costumbres de la guerra. Adoptada el 18 de octubre de 1907. 


\section{Jurisprudencia}

\subsection{Jurisprudencia nacional}

\subsubsection{Corte Constitucional}

Sentencia C-540 de 2012.

Sentencia C-540 de 2011.

Sentencia C-980 de 2010.

Sentencia C-913 de 2010.

Sentencia C-334 de 2010.

Sentencia C-131 de 2009.

Sentencia C-025 de 2009.

Sentencia C-1011 de 2008.

Sentencia T-916 de 2008.

Sentencia T-708 de 2008.

Sentencia C-336 de 2007.

Sentencia C-291 de 2007.

Sentencia T-233 de 2007.

Sentencia C-210 de 2007.

Sentencia C-355 de 2006.

Sentencia C-782 de 2005.

Sentencia C-591 de 2005.

Sentencia T-787 de 2004.

Sentencia C-1092 de 2003.

Sentencia T-881 de 2002.

Sentencia T-729 de 2002.

Sentencia su-159 de 2002.

Sentencia C-392 de 2000.

Sentencia C-372 de 1997. 
Sentencia T-696 de 1996.

Sentencia C-657 de 1996.

Sentencia C-626 de 1996.

Sentencia C-382 de 1996.

Sentencia C-225 de 1995.

Sentencia T-211 de 1994.

Sentencia T-349 de 1993.

Sentencia C-574 de 1992.

Sentencia T-414 de 1992.

Sentencia T-011 de 1992.

\subsubsection{Corte Suprema de Justicia-Sala de Casación Penal}

Rad. 39.948, Auto de segunda instancia de 21 de noviembre de 2012.

Rad. 37.365, Auto de 21 de noviembre de 2011.

Rad. 35.099, Sentencia de 23 de marzo de 2011.

Rad. 33.621, Sentencia de 10 de marzo de 2010.

Rad. 32.805, Sentencia de 23 de febrero de 2010.

Rad. 31.073, Sentencia de 1 de julio de 2009.

Rad. 29.853, Sentencia de 29 de agosto de 2008.

Rad. 26.118, Sentencia de 19 de diciembre de 2007.

Rad. 26.118, Auto de acusación de 10 de julio de 2007.

Rad. 23.284, Sentencia del 5 de octubre de 2006

Rad. 21.529, Sentencia de 7 de septiembre de 2006.

Rad. 24.679, Sentencia de 27 de julio de 2006.

Rad. 18.103, Sentencia de 2 de marzo de 2005.

Rad. 10.656, Sentencia de 24 de noviembre de 2004.

Rad. 18.451, Sentencia de 8 de julio de 2004.

Rad. 21.216, Sentencia de 6 de agosto de 2003. 
Rad. 13.148, Sentencia de 21 de noviembre de 2002.

Rad. 13.948, Sentencia de 30 de noviembre de 2001.

Rad. 13.255, Sentencia de 23 de noviembre de 2000.

Rad. 9.579, Sentencia de 22 de octubre de 1996.

\subsubsection{Otros foros jurisdiccionales nacionales}

Tribunal Superior del distrito judicial de Bogotá, Rad. 110010704003-2008-00025-09, Sentencia del 30 de enero de 2012.

Tribunal Superior del distrito judicial de Bogotá, Rad. 110010704003-2008-00025-09. Aclaración y Salvamento de Voto de la Sentencia de 30 de enero de 2012.

Tribunal Superior del Distrito Judicial de Bogotá, Rad. 110010704002-2007-00056-01(09-10), Sentencia del 25 de mayo de 2011.

Juzgado Tercero Penal del Circuito Especializado de Bogotá. Rad. 1100113207003-2008-00025-00, Sentencia de 9 de junio de 2010.

\subsection{Jurisprudencia internacional}

\subsubsection{Corte Europea de Derechos Humanos}

Caso Niculescu v. Rumania, Sentencia 25 de junio de 2013.

Caso Valentino Acatrinei v. Rumania, Sentencia de 25 de junio de 2013.

Caso P.G y J.H v. Reino Unido, Sentencia de 25 de septiembre de 2001.

Caso Khan v. Reino Unido, Sentencia de 12 de mayo de 2000. Caso Schenck v. Suiza, Sentencia de 12 de julio de 1988. 
Caso Schenck v. Suiza, Opinión disidente conjunta de los jueces Pettiti, Spielmann, De Meyer y Carrillo Salcedo; Opinión disidente conjunta de Pettiti y De Meyer; y Opinión disidente de De Meyer de la Sentencia de 12 de julio de 1988.

Caso Malone v. Reino Unido, Sentencia de 2 de agosto 1984.

\subsubsection{Corte Interamericana de Derechos Humanos}

Caso Cabrera García y Montiel Flores v. México, Sentencia de 26 de noviembre de 2010.

Caso Escher y otros v. Brasil, Sentencia de 6 de julio de 2009.

Caso Tristán Donoso v. Panamá, Sentencia de 27 de enero de 2009.

Caso Bayarri v. Argentina, Sentencia del 30 de octubre de 2008.

Caso de la masacre de Mapiripan v. Colombia, Sentencia 15 de septiembre de 2005.

Caso Lori Berenson Mejía v. Perú, Sentencia de 25 de noviembre de 2004.

Caso Durand y Ugarte v. Perú, Sentencia del 16 de agosto de 2000.

Caso Cantoral Benavides v. Perú, Sentencia de 18 de agosto de 2000.

Caso Castillo Petruzzi y otros v. Perú, Sentencia del 30 de mayo de 1999.

Opinión Consultiva, Garantías judiciales en estados de emergencia, OC-9/87, de 6 de octubre de 1987.

Opinión Consultiva, El hábeas corpus bajo suspensión de garantías, OC-8/87, de 30 de enero de 1987. 


\subsubsection{Corte Penal Internacional}

Situación de la República del Congo

Sala de Primera Instancia I, Prosecutor v. Thomas Lubanga

Dyilo. Judgment pursuant to Article 74 of the Statute (ICC-01/04-01/06) de 14 de marzo de 2012.

Sala de Primera Instancia I, Prosecutor v. Thomas Lubanga Dyilo. Corrigendum to Decision on the admissibility of four documents (ICC-01/04-01/06-1399-Corr) de 20 de enero de 2011.

Sala de Cuestiones Preliminares I, Prosecutor v. Thomas Lubanga Dyilo. Decision on the confirmation of charges (ICC-01/04-01/06-803-tEN) de 29 de enero de 2007.

Sala de Primera Instancia II, Prosecutor v. Mathieu Ngudjolo. Judgment pursuant to article 74 of the Statute (ICC01/04-02/12-3) de 18 de diciembre de 2012.

Sala de Cuestiones Preliminares I, Prosecutorv. Callixte Mbarushimana. Decision on the confirmation of charges (ICC-01/04-01/10-465-Red) de 16 de diciembre de 2011.

Situación de la República Centroafricana

Sala de Apelaciones, Prosecutor v. Jean Pierre Bemba Gombo.

Sentencia relativa a las apelaciones del Sr. Jean-Pierre Bemba Gombo y el Fiscal contra la decisión de la Sala de Primera Instancia III titulada "Decisión relativa a la admisión como pruebas de los materiales contenidos en la lista de pruebas de la Fiscalía” (ICC-01/05-01/081386-tSPA) de 3 de mayo de 2011. 
Sala de Primera Instancia III, Prosecutor v. Jean-Pierre Bemba. Decision on the admission into evidence of materials contained in the prosecution's list of evidence (ICC01/05-01/08-1022) de 19 de noviembre de 2010.

Sala de Cuestiones Preliminares II, Caso Prosecutor v. JeanPierre Bemba Gombo. Decision Pursuant to Article 61(7) (a) and (b) of the Rome Statute on the Charges of the Prosecutor Against Jean-Pierre Bemba Gombo (ICC01/05-01/08-424) de 15 de junio de 2009.

\subsubsection{Tribunal Penal Internacional para Ruanda}

Sala de Apelaciones, Prosecutor v. Musema. Judgment (ICTR96-13-A) de 27 de enero de 2000.

Sala de Primera Instancia, Prosecutor v. Bogosora et al. Decision on admission of tab 19 of binder produced in connection with appearance of witness Maxwell Nkole (ICTR-98-41-T) de 13 de septiembre de 2004.

\subsubsection{Tribunal Penal Internacional para la ex-Yugoslavia}

Sala de Primera Instancia, Prosecutor v. Mladic, Ratko. Decision on prosecution's bar table motion for the admission of intercepts: srebrenica segment (IT-09-92-T) de 2 de mayo de 2013.

Sala de Primera Instancia, Prosecutor v. Karadžić, Radovan. Decision on accused's motion for reconsideration of denial of defence intercepts (IT-95-5/18-T) de 22 de enero de 2013.

Sala de Primera Instancia, Prosecutor v. Karadžić, Radovan. Decision on prosecution's third bar table motion for the 
admission of intercepts (Srebrenica) (IT-95-5/18-T), de 24 de mayo de 2012.

Sala de Primera Instancia, Prosecutor v. Karadžić, Radovan. Decision on prosecution's first bar table motion for the admission of intercepts (IT-95-5/18-T), de 14 de mayo de 2012.

Sala de Primera Instancia, Prosecutor v. Karadžić, Radovan. Decision on the prosecution's motion for judicial notice of intercepts related to the Sarajevo component and request for leave to add one document to the rule 65 ter exhibit list (IT-95-5/18-T) de 4 de febrero de 2011.

Sala de Primera Instancia, Prosecutor v. Karadžić, Radovan.

Decision on the accused's motion to exclude Intercepted Conversations (IT-95-5/18-T) de 30 de septiembre de 2010.

Sala de Primera Instancia, Prosecutor v. Tolimir, Zdravko. Judgment (IT-05-88/2-T) de 12 de diciembre de 2012. Sala de Primera Instancia, Prosecutor v. Tolimir, Zdravko. Decision on prosecution's motion for admission of 28 intercepts from the bar table (IT-05-88/2-T) de 20 de enero de 2012.

Sala de Primera Instancia, Prosecutor v. Popovic et al. Judgment (IT-05-88-T) del 10 junio de 2010.

Sala de Primera Instancia, Prosecutor v. Popovic et al. Decision on Admissibility of intercepted communication (IT-0588-T) de 7 de diciembre de 2007.

Sala de Primera Instancia, Prosecutorv. Martic, Milan. Decision adopting guidelines on the standards governing the admission of evidence (IT-95-11-T) de 19 de enero de 2006. 
Sala de Primera instancia, Caso Prosecutor v. Blagojevic and Jokic. Decision on the Admission into Evidence of Intercept-related Materials (IT-02-60-T) de 18 de diciembre de 2003.

Sala de Primera Instancia, Prosecutor v. Brdanin, Radoslav. Decision on the defence objection to intercept evidence (IT -99-36-T) del 3 de octubre de 2003.

Sala de Primera Instancia, Prosecutor v. Krstic, Radislav. Judgment (IT-98-33-T) de 2 de agosto de 2001.

Sala de Primera Instancia, Prosecutor v. Delalic et al. Decision

On the Tendering of Prosecution Exhibits 104-108 (IT96-21-T) de 9 de febrero de 1998.

Sala de Primera Instancia, Prosecutor v. Delalic et al. Decision on zdravko mucic's motion for the exclusion of evidence (IT-96-21-T) de 2 de septiembre de 1997.

Sala de Apelaciones, Prosecutor v. Dusko Tadic. Decision on the defence motion for interlocutory appeal on jurisdiction (IT-94-1-A) de 2 de octubre de 1995. 

Este libro fue compuesto en caracteres

Stempel Garamond 12 puntos, sobre papel propal de 70 gramos y encuadernado con método Hot Melt, en septiembre de 2015, en Bogotá, D. C., Colombia

Digiprint 